\title{
Drivers of Change to Mountain Sustainability in the Hindu Kush Himalaya
}

\author{
Coordinating Lead Authors \\ Yanfen Wang, University of Chinese Academy of Sciences, Beijing, China, e-mail: yfwang@ucas.ac.cn \\ Ning Wu, International Centre for Integrated Mountain Development, Kathmandu, Nepal; and Chengdu \\ Institute of Biology, Chinese Academy of Sciences, Chengdu, China, \\ e-mail: wuning@cib.ac.cn (corresponding author)
}

\section{Lead Authors}

Clemens Kunze, International Centre for Integrated Mountain Development, Kathmandu, Nepal, e-mail: clemens.kunze@icimod.org

Ruijun Long, International Centre for Integrated Mountain Development, Kathmandu, Nepal, e-mail: ruijun.long@icimod.org

Manfred Perlik, Centre for Development and Environment, University of Bern, Switzerland; and Laboratoire Pacte/LabEx ITEM, University of Grenoble, France, e-mail: manfred.perlik@cde.unibe.ch

\section{Contributing Authors}

Neha Bisht, International Centre for Integrated Mountain Development, Kathmandu, Nepal, e-mail: neha.bisht16@gmail.com

Huai Chen, Chengdu Institute of Biology, Chinese Academy of Sciences, Chengdu, China, e-mail: chenhuai@cib.ac.cn

Xiaoyong Cui, University of Chinese Academy of Sciences, Beijing, China,

e-mail: cuixy@ucas.ac.cn

Rucha Ghate, International Centre for Integrated Mountain Development, Kathmandu, Nepal,

e-mail: ruchaghate@gmail.com

Srijana Joshi, International Centre for Integrated Mountain Development, Kathmandu, Nepal,

e-mail: srijana.joshi@icimod.org

Abhimanyu Pandey, International Centre for Integrated Mountain Development, Kathmandu, Nepal,

e-mail: abhimanyu.pandey@icimod.org

Jianqiang Zhang, Institute of Mountain Hazard and Environment, Chinese Academy of Sciences, Chengdu, China, e-mail: zhangjq@imde.ac.cn

\section{Review Editor}

Marc Foggin, Mountain Societies Research Institute, University of Central Asia, Kyrgyzstan | Tajikistan | Kazakhstan; and Institute of Asian Research, University of British Columbia, Canada, e-mail: marc.foggin@ucentralasia.org

\section{Corresponding Author}

Ning Wu, International Centre for Integrated Mountain Development, Kathmandu, Nepal; and Chengdu Institute of Biology, Chinese Academy of Sciences, Chengdu, China,

e-mail: wuning@cib.ac.cn 


\section{Contents}

Chapter Overview.

2.1 Pillars and Drivers of Sustainability in HKH Mountains

2.2 Environmental Drivers of Change to Mountain Sustainability

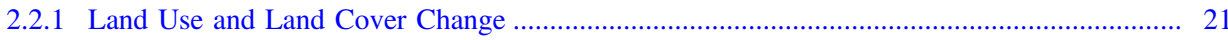

2.2.2 Over-Exploitation of Natural Resources ........................................................................... 23

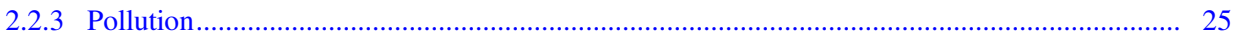

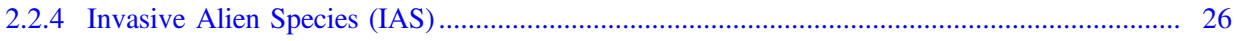

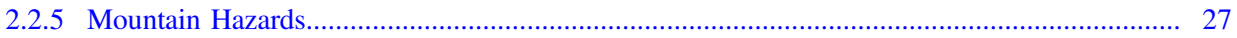

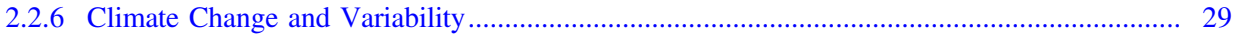

2.3 Sociocultural Drivers of Change to Mountain Sustainability ............................................... 31

2.3.1 Changing Demographic Situation .............................................................................. 31

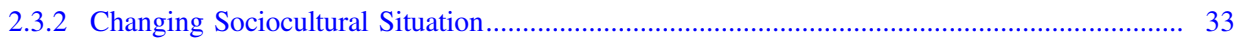

2.3.3 Governance Systems and Institutions ……..................................................................... 34

2.3.4 External Knowledge and Technological Innovations ....................................................... 35

2.4 Economic Drivers of Change to Mountain Sustainability ..................................................... 37

2.4.1 Economic Growth and Differentiation ....................................................................... 37

2.4.2 Rapid Infrastructure Development ................................................................................ 39

2.4.3 Urban and Peri-urban Expansion ...................................................................................... 40

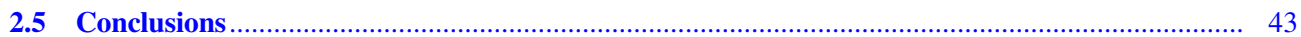

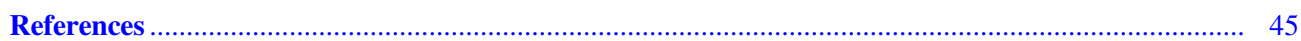

\section{Chapter Overview}

\section{Key Findings}

1. Looming challenges characterize the HKH as environmental, sociocultural, and economic changes are dynamically impacting livelihoods, environmental conditions, and ultimately sustainability. Many challenges for sustainability are related to weak governance, natural resource overexploitation, environmental degradation, certain aspects of unregulated orrapidurbanization, andloss of traditionalculture. Addressing these problems will require policy andaction at local, national, and international levels, including common action among HKH states.

2. However, for mountain societies of the HKH, some changes may also bring novel opportunities for sustainable development. A range of opportunities lie in improved connectivity including transportation and communication, which increases access to information, partnerships, and markets. Enhanced access to social services may be enabled and strengthened by economic growth and the advancement of science and technology. Additionally, a growing network of local urban centres may support the transmission of new prosperity to rural populations, as the development of mountain towns and cities often can help-besides their mere economic power-to enhance the political influence of these regions within the national states.

3. The drivers of change to environmental, sociocultural, and economic sustainability in the HKH are interactive, inextricably linked, and increasingly influenced by regional and global developments. Among the most important drivers in this intricate network of causes and effects are demographic changes and current governance systems, as well as land use and land cover change, over-exploitation of natural resources, economic growth and differentiation, and climate change. 


\section{Policy Messages}

1. To meet the challenges arising from environmental, sociocultural, and economic changes in the HKH, policy approaches must become more holistic and multidimensional. While the drivers of change continue to demand individual identification and analysis, the complexity of their interactions also calls for more comprehensive and integrated strategies to be adopted-incorporating globally recognized mountain priorities, promoting transboundary cooperation, and encouraging development of mountainspecific responses by government policy makers.

2. Governments should take strong and timely action to strengthen the sociocultural and environmental dimensions of sustainability, while also fostering responsible economic growth in the mountain regions. Such interventions should be developed with more inclusive, participatory approaches in natural resource management. Both proximate and ultimate drivers of change must be recognized and incorporated into national development planning. This is the Mountain Agenda.

3. Regional governments should combine and accelerate efforts to advance sustainable mountain development, especially with a view to benefiting from the global conservation and development agenda, such as the Sustainable Development Goals for 2030. New financing mechanisms for climate change mitigation and adaptation and for infrastructure development offer valuable opportunities for increased investment in mountain regions. Governments must seize these, with the aim of creating enabling environments and institutions that empower mountain people to share in the regional and global achievements and benefits of inclusive growth and sustainable development.

What are the main drivers of change affecting mountain sustainability in the HKH? This chapter seeks answers to this critical question. Building on the definition of sustainability given by the United Nations' Agenda 21, we describe environmental, sociocultural, and economic dimensions of change and their drivers in the HKH. Specifically, we aim to outline and describe trends and existing and potential impacts of a varied and sometimes complex set of drivers of mountain sustainability.

A comprehensive analysis of the major drivers leading to changes in the HKH reveals that individual and cumulative impacts are reflected at multiple spatial and temporal scales (well established). For example, globalization, climate change, and the rapid spread of invasive alien species exist or occur in many localities and across many scales. As a result, in any given area or community, the interactions and impacts of these and other drivers of change are complex, and often are local and specific in the context of the dominant ecosystem or landscape and the sociocultural and economic environments.

The HKH is among the most discrete yet diverse regions of the world in terms of environmental, sociocultural and economic settings. It represents globally significant biodiversity hotspots and provides numerous ecosystem services to millions of people living within as well as outside the region (well established). The HKH region also faces enormous pressures from both global and regional change, and from a combination of both natural and anthropogenic forces (well established).

In most areas of the HKH, rapid demographic and economic growth have increased the demand for natural resources leading in many instances to their overexploitation, significant land use and land cover change (LULCC), habitat fragmentation, and unsustainable socioeconomic activities (well established). Rapid economic growth has changed levels and patterns of consumption as well as infrastructure investment. For example, dam construction for irrigation may make food production more efficient and create opportunities to export food, while those dams built for hydropower can improve livelihoods locally with the provision of electricity as well as energy for export, and may also transform agricultural communities through diversification of livelihood opportunities such as tourism. However, all large scale investments also have a multitude of intended or unintended effects, some of which are negative, including social and environmental consequences (established but incomplete). Similarly, demographic shifts, with people increasingly concentrated in town and cities, are expected to create future challenges through environmental impacts caused especially by a growing demand for food and energy, yet at the same time may also lead to improved quality of and access to social services such as education, health care and waste management (established but incomplete).

Technological innovations have markedly affected people's ways of life in the HKH, especially local and indigenous sociocultural practices, enabled through the development of a range of opportunities in remote mountain areas (established but incomplete). With a gradual integration into regional and global markets, many rural societies in the region-though not all-are now shifting from subsistence farming to more market-based agricultural production, including cash crops. Such changes have contributed to the conversion of croplands to non-agricultural use, to a decline in traditional ways of life, and also to a more intense use of natural resources - along with rising incomes and enhanced livelihoods, albeit not uniformly amongst all people or groups (established but incomplete). Advances in agricultural technology and 
biotechnology may improve the yield of crops and people's food security, yet arguable with a bundle of uncertainties (established but incomplete), while the increased access to global ICT services including smartphones, open access software and cloud computing can make mountain regions more accessible (established but incomplete).

Several major drivers, in particular demographic changes, governance systems and institutions, and climate change, are likely to have the most harmful or challenging impacts on sustainable development in the HKH (established but incomplete). As HKH countries work to adapt their practices and mitigate these impacts, all their efforts must involve close collaboration among countries. Weak governance and uncertain or unsecure land tenure, in particular, along with political unrest, local conflicts and migration, are also exacerbating environmental degradation through various activities such as poaching, unsustainable timber harvesting, and other forms of over-exploitation of natural resources (established but incomplete).

All the above challenges create an urgent need for improved coordination amongst development stakeholders including governments for formulating evidence-based policies and legislation, for developing more effective institutional arrangements, for more transparent decision making, and for greater transboundary cooperation in regional aspects of conservation and development across the HKH.

\subsection{Pillars and Drivers of Sustainability in HKH Mountains}

Mountain systems have long been admired and protected on the grounds of their serenity, wilderness, and landscape beauty (Antonelli 2015; Foggin 2016; Messerli and Ives 1997; Price 2015). Although direct human influence on the world's mountains is relatively low, when compared to more densely populated lowlands, nonetheless many mountain systems are strongly affected by multiple local and global drivers of change (Price 2015).

Decisions and actions taken by a diverse range of stakeholders operating at many scales in the HKH impact the overall sustainability in mountains. Drivers of change affect sustainability through environmental, sociocultural, or economic dimensions, either individually or in combination. In addition, local processes may have regional and global impacts, and vice versa. The origin and impact of key drivers of change in the HKH-which will be introduced in this chapter - are manifest at three main levels or scales: (1) direct local impacts of drivers on land and natural resources and their management, within a framework of coupled socialecological systems; (2) regional effects of local drivers, mediated largely through provision of ecosystem services in the context of highland-lowland linkages; and (3) regional and global influences on the HKH through tele-coupled systems, whereby decisions or actions made outside the region have significant impacts within the HKH. In the widely interconnected spheres of influence of each driver, multiple pathways of impact are common, including both direct and indirect associations with mountain sustainability.

There are also three primary dimensions or pillars of sustainability. Ensuring that the needs of the present generation are met without compromising the ability of future generations to meet their own needs requires that the environment be safeguarded from degradation or loss, that development occurs in socially and culturally appropriate and equitable ways, and that development plans and interventions be economically viable. In mountain regions, additional complexities are introduced because of upstreamdownstream linkages (e.g., flow of ecosystem services) and the multi-scalar nature of many of the key drivers and/or their impacts (cf. tele-coupled systems) (see Box 2.1).

\section{Box 2.1 What is mountain sustainability?}

Sustainability has environmental, sociocultural, and economic dimensions. Healthy ecosystems and environments are necessary for the survival of humans and other organisms, and thus constitute the basis of sustainable development. Yet without sociocultural equity or viable economic plans and initiatives, few development interventions will succeed. The three dimensions or pillars of sustainability are interdependent and mutually reinforcing, and - in the long run - none can exist without the others (Morelli 2011). Moving towards sustainability is a societal challenge that involves national and international legislation, urban and regional development, transport and other sectors, and that equally involves engagement with local and individual ways of life, and, especially in an increasingly urban world, positive choices to promote more ethical consumerism.

In mountain regions such as the $\mathrm{HKH}$, linkages are critical between upstream and downstream ecosystems, people, and production systems, as well as between centres of decision making and remoter mountain communities. Achieving sustainability in the HKH will require not only that drivers of change and their pathways of impact be clearly identified and addressed, but also that regional and transboundary coordination and collaboration are endorsed, promoted, and strengthened across all relevant sectors.

Because human-related drivers affect mountain sustainability at different spatial and temporal scales, both the assessment and management of these drivers are complex matters. Changes in one driver generally result in interactive 


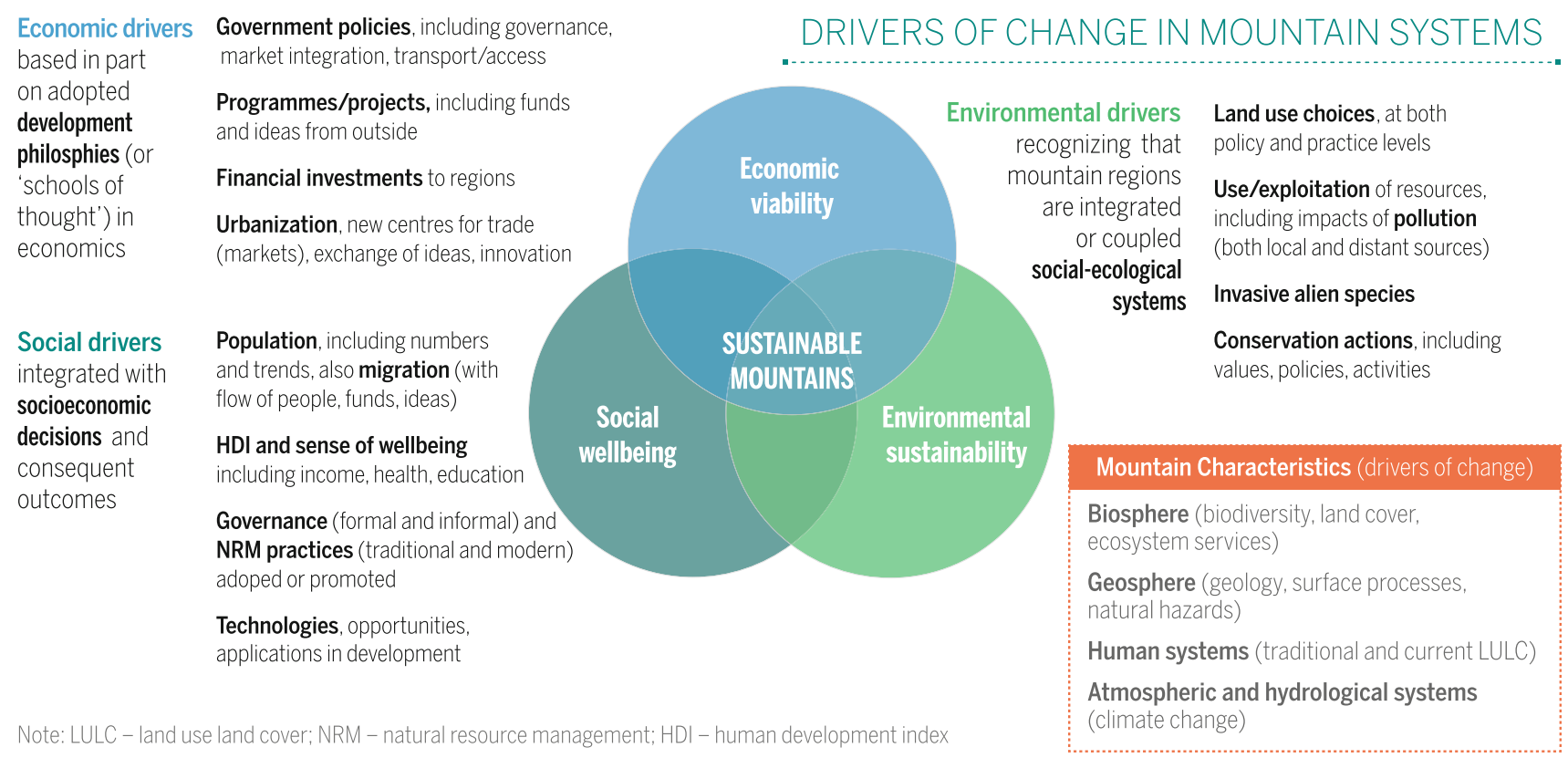

Fig. 2.1 Model of three pillars of mountain sustainability and network of interactive drivers of change (Source developed by Marc Foggin for this chapter). Note LULC: Land use and land cover; NRM: Natural resource management; HDI: Human development index

or feedback effects on other drivers. That is, for any given change, the effects are always multiple and often interactive; there is no simple one-to-one causal link between one driver of change and a single aspect of mountain social-ecological systems.

Further, certain drivers of change are themselves the result of complex combinations of multiple other factors. Causality is almost always mediated by a range of interacting factors, complicating attempts to establish the proportionality of various contributors to change. Therefore, although the following sections address a suite of drivers of change separately, each in turn, their combined effects should be kept in mind along with their respective effects on the three different dimensions of sustainability-environmental, sociocultural, and economic.

Figure 2.1 provides a conceptual illustration (model) of mountain sustainability and the key drivers of change, broadly organized around the concept of the three pillars of sustainability. Throughout this chapter, however, it will become evident that the impacts of each individual driver almost always range across all of these dimensions.

In summary, this chapter presents a high-level review and assessment of available information about the main drivers of change to mountain sustainability in the $\mathrm{HKH}$, with a review of their multidimensional impacts across a range of scales and introducing their major pathways of impact. Notably, not every element in the conceptual model shown in Fig. 2.1 is substantiated with full studies or information directly from the $\mathrm{HKH}$ - a number of gaps still exist—but the drivers detailed in this chapter are largely overlapping and consistent with the model.

\subsection{Environmental Drivers of Change to Mountain Sustainability}

This section focuses on the multiple, interrelated effects of land use and land cover change, levels of resource exploitation, forms of pollution, presence of invasive alien species, mountain hazards, and climate change, as the main (direct) environment-related drivers of change to mountain sustainability.

\subsubsection{Land Use and Land Cover Change}

Land use and land cover change (LULCC) directly impacts the environment and leads to socioeconomic changes for human communities. LULCC is the primary cause of soil degradation, altering ecosystem functions and services, thus affecting the abilities of ecosystems to support human needs -both locally and downstream. In this way LULCC largely determines (or mediates) both the vulnerability and the resilience of ecosystems and human society to external perturbations such as climate change, national and regional policies, and other aspects of globalization.

Integrated research on LULCC across the HKH is generally lacking. Most published case studies have been carried 


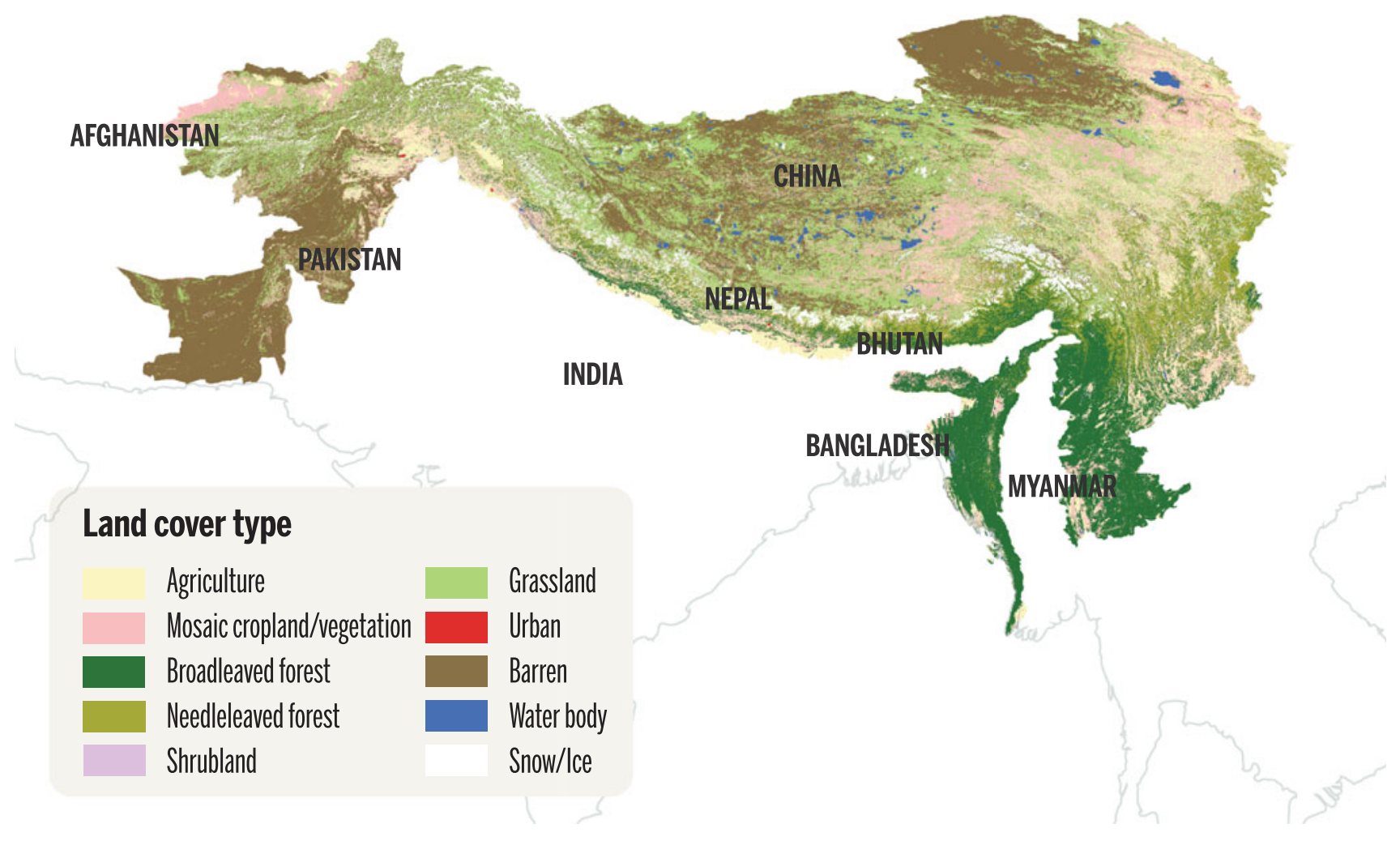

Fig. 2.2 Main land cover types in the Hindu Kush Himalaya

out in the Tibetan Plateau region in China, focusing especially on the vast grasslands. Because most available case studies analyse satellite data that are temporally and spatially variable, regional patterns of LULCC are difficult to distinguish clearly (Harris 2010; Box 2.2).

\section{Box 2.2 General trends of LULCC in the HKH}

The HKH encompasses a total land area of 3.4 million $\mathrm{km}^{2}$, more than half of which is rangeland, specifically grasslands and shrubland (Fig. 2.2). Grasslands are the dominant form and include alpine pastures and meadows. Most of the shrubland used for grazing is distributed above the tree line. In addition, forests occupy approximately $14 \%$ of the region, comprising broad-leaved forests, needle-leaved forests and plantations. Around $25 \%$ of the area is classified as agricultural land. Wetlands cover under $10 \%$ of the HKH.

The most significant LULCC in recent decades has been caused by degradation of grasslands and deforestation at lower altitudes. Other significant transitions have been the transformation of forest and grassland to farmland, shrinkage of wetland, and LULCC related to urban and infrastructure developments (Cui and Graf 2009; Jin et al. 2010). In some cases, however, the recent implementation of large-scale ecological restoration programmes in $\mathrm{HKH}$ countries has slowed and sometimes even reversed the trend of degradation (Cai et al. 2015).

HKH rangelands support high floristic richness and large numbers of wild and domesticated animals. Forests provide important altitudinal connectivity for species between lowland and mountain habitats. The croplands have a diversity of mostly mixed farming systems, containing a rich genetic diversity of cultivated plants and livestock breeds (ICIMOD 2009). Wetlands also provide habitats for several globally significant migratory birds (Gujja et al. 2003; Sharma et al. 2010). However, when LULCC occurs, the quality and quantity of these habitats are impacted, affecting a wide range of organisms.

Extensive research has shown that degradation of grassland has spread over the past few decades across the whole high-altitude areas of the HKH (Wu et al. 2013). In the Tibetan Plateau of China, high-altitude grassland is sensitive to disturbance, especially in its drier part, where the removal of turf is irreversible. In the north-east portion of the Tibetan Plateau, many alpine meadows have been seriously degraded since the 1960s (Wang et al. 2008). By some measures, 'degraded grassland' constituted approximately $92 \%$ of the 
total area of usable grassland in 2004, of which severely and moderately degraded grassland accounted for $38 \%$ and $54 \%$, respectively (Wang et al. 2008). Additionally, the areas of alpine meadow and swamp meadow decreased by around $4 \%$ and $25 \%$, respectively, in the 1970 s and 1980s; they decreased by almost another $25 \%$ and $35 \%$, respectively, in the 1990s (Zhou et al. 2008).

Wetlands and lakes constitute around $5 \%$ of the total area of the Tibetan Plateau, but this area decreased by about $5 \%$ between 1990 and 2000, due primarily (84\%) to wetland shrinkage ( $\mathrm{Li}$ and Xue 2010). In contrast, lake expansion was also found in some high-altitude belts (Liu et al. 2009, 2010) such as the source areas, or headwaters, of the Yangtze River, Yellow River, and Mekong River in the central Tibetan Plateau; this is attributed to glacier melting caused by global warming (unpublished data).

In addition, warm-temperate coniferous forest has nearly disappeared from the south-east Tibetan Plateau, mostly due to commercial logging before the end of the 1990s (Cui and Graf 2009). In the high mountainous areas of Pakistan, the forested area decreased by $30 \%$ from 1968 to 2007 , one-third being caused by agricultural expansion (Qasim et al. 2013). In the same region, agricultural lands in mid-elevation zones expanded by $70 \%$ and forests decreased by $50 \%$. At lower altitudes agricultural lands more than doubled-expanding by $130 \%$ and causing a decrease of over $30 \%$ in the forested area between 1968 and 2007, when annual deforestation rates were $0.80 \%, 1.28 \%$, and $1.86 \%$ at high, mid- and low altitudes, respectively (Qasim et al. 2013). An annual loss of $0.2 \%$ in forested area has been reported for the Indian mountains (Reddy et al. 2013) and of $0.3 \%$ for Myanmar (Leimgruber et al. 2005). However, forest cover in Bhutan is increasing at an annual rate of $0.22 \%$ (Gilani et al. 2015).

Changes in LULCC in HKH, as elsewhere, are caused by a combination of natural drivers such as climate change and human activity such as land conversion. Recent warming trends on the Tibetan Plateau, for example, directly influence the extent of permafrost cover and the degree of snow melting. Human activities also have intensified rapidly on the plateau over the last half century, with significant impact on land use. Desertification on the northern Tibetan Plateau is attributed almost equally to climatic changes and human activities, with climatic factors taking a slight lead (Yang et al. 2004). However, the magnitude and the extent of land cover changes under future global warming scenarios are difficult to assess because of deficits in current global climate models in this topographically complex area (Cui and Graf 2009).

Studies using Landsat images show that climatic change, human activities, animal and insect damage, and government policies all influence LULCC. During one 16-year study period (1994-2010) LULCC was shown mainly to occur slowly, and was linked to both natural and anthropogenic pressures (Song et al. 2009). Although political tools such as key national projects to improve ecological conditions could help with revegetation and slow desertification, the harsh natural conditions and fragility of this high-altitude region make it extremely difficult for degraded land to be rehabilitated (Song et al. 2009).

Policy decisions also influence LULCC in the HKH, as elsewhere. The de facto privatized use of wetlands by individuals or groups of households on the basis of long-term leases or selling, for example, has negatively impacted many aspects of hydrologic function, landscape conditions, and biodiversity in wetlands in the eastern HKH (Narain and Singh 2017; Yan and $\mathrm{Wu}$ 2005). The uneven spatial distribution of water resources on private lands, in particular, has led to the practice of actively extracting groundwater, which has lowered the water table. Fencing rangelands to limit grazing on expanding sand dunes also has affected some landscapes negatively, as consequent year-round use of other pastures that previously were grazed only in summer has in effect shrunk the overall activity space of some wildlife species (Yan and Wu 2005).

Market-driven changes in crop and livestock production strategies equally affect land use in HKH. Over the past 1015 years, five HKH countries (Bhutan, China, India, Nepal, and Pakistan) have seen increasing trends in crop diversification, generally moving towards horticultural and cash crops. Forest transition due to plantations, agricultural intensification, and infrastructure development have led to many large-scale LULCC in mountains (Xu et al. 2009; Sharma et al. 2010). These trends have positive implications for the future development of mountain agriculture in terms of harnessing mountain niche products with their comparative advantages (Tulachan 2001).

In the livestock sector, there is a general decline in the cattle population across the $\mathrm{HKH}$ which could, for example, permit greater development of smallholder dairies with improved buffaloes in the Himalayan subtropics, and consequently contribute to enhanced food security and nutrition in mountain households (Tulachan 2001). In Afghanistan, the nature of the topography and arid climate means that vast areas are subject to soil erosion (Saba 2001). Loss of vegetation and soil humus creates ever drier conditions. Land abandonment, poor reclamation schemes, overgrazing, and the removal or destruction of vegetation as fuel have all contributed to widespread desertification (Saba 2001), which further impacts negatively on the pastoral production and livelihoods of local people in arid and semi-arid areas.

\subsubsection{Over-Exploitation of Natural Resources}

Exploitation of natural resources is one of the major environmental problems and drivers of change in mountains. 
Over-exploitation includes the destruction of forest and shrublands for fuelwood and for commercial timber collection, overharvesting of non-timber forest products (NTFPs) such as medicinal plants, overgrazing, overfishing, and unsustainable and/or illegal mining (Dhanai et al. 2015; Shrestha and Bawa 2015; Shrestha and Dhillion 2003; Uniyal et al. 2002).

Generally, demands for natural resources increase in tandem with local and regional socioeconomic development. Demand pressures are further exacerbated by population growth. Together, these two factors are the main (ultimate) driving forces leading to over-exploitation in HKH (Poudel and Shaw 2015; Tsering et al. 2010). In the medium to long term, resource over-exploitation always results in the degradation of ecosystems, often followed by loss of genetic diversity and the extinction of species (Kaur et al. 2012). A decline in the provision of ecosystem services, including the loss of biodiversity, ultimately has disastrous effects on human wellbeing.

\subsubsection{Extraction of Non-timber Forest Products (NTFPs)}

NTFPs contribute significantly to people's livelihoods in the $\mathrm{HKH}$, especially in forest-dependent communities, by strengthening or increasing local food security, incomes, health, and sustainable human development. There is ample evidence of the importance of NTFPs for rural livelihood improvement from across the region (Johnson et al. 2013; Mukul et al. 2010; Negi et al. 2011; Uprety et al. 2010; Yadav and Dugaya 2013). The collection of NTFPs has increased in $\mathrm{HKH}$ to meet growing demands in national and international markets, where they constitute increasingly important ingredients in herbal cosmetics, herbal tea, food, and medicines (Banjade and Paudel 2008). For example, unsustainable and illegal harvesting of NTFPs has been reported as one of the major issues in the Kanchenjunga landscape, with challenges arising in sustainable conservation and management of NTFPs (Uprety et al. 2016). In the central and eastern Himalaya, unsustainable collection and trade in yarsagumba (or caterpillar fungus, Cordyceps sinensis) — the world's most expensive biological resourceis regarded as a major driver of its population decline (Gruschke 2011; Shrestha and Bawa 2013).

\subsubsection{Unsustainable Grazing}

Overgrazing by domestic livestock is one of the main causes of degradation of plant and soil resources. By most estimates, the majority of rangelands in the HKH are regularly grazed beyond their carrying capacity (Dong et al. 2007; 2009; Harris 2010; Ho 2001). Overgrazing not only alters the vegetation composition, but also has other impacts such as soil erosion and degradation, declines in soil nutrient content and carbon storage, and altered stream flow regimes
(Aryal et al. 2015; Dong et al. 2010; Sharma et al. 2014; Wen et al. 2013). Livestock grazing in HKH rangelands may be unsustainable (sometimes with irreversible damage to land and plant resources) not only because of total numbers of livestock, but also due to seasonality of grazing patterns, short- and long-term grazing intensities, and the composition of livestock herds (Ho 2001; Li et al. 2014).

\subsubsection{Illegal Hunting}

Illegal hunting (poaching) and trade in wildlife or wildlife parts also are major direct threats to biodiversity, and are particularly acute in the region's protected areas (Katuwal et al. 2015; Khan et al. 2016). The threat of illegal hunting is most severe for vertebrates such as rhinoceros, tiger, musk deer, pangolin, and red panda-driven especially by the demand for wildlife parts and products on the international market (Kumar et al. 2016). Traditional medicine plays an important role in health care in countries such as China, Nepal, and India, and while numerous measures have been adopted to reduce the use of wild species in traditional medicine there is still a growing market demand (Liu et al. 2016). Wildlife poaching, combined with retaliatory killing by local community members following livestock depredation, have the potential to drive species towards local extinction (Simms 2011). In the case of snow leopard alone, Li and Lu (2014) identified a total of 43 instances of traded snow leopard parts across China's borders between 2000 and 2013, primarily pelts and some bones, involving 98 snow leopard individuals.

\subsubsection{Tourism}

The HKH has tremendous potential for mountain tourism, which can provide alternative, environmentally friendly employment opportunities for local communities and contribute positively to their socioeconomic wellbeing. In most of the region, however, tourism development is poorly planned, often even unplanned, and the development of infrastructure such as recreational facilities, guest houses, camping sites, and restaurants often have significant negative impacts on the mountain environment (Dorji 2001; Nepal 2005, 2011). Tourism also contributes to ecosystem degradation through unregulated disposal of solid waste, trampling of soil and vegetation, and locally intensified resource extraction. The infrastructure deemed necessary to sustain tourism also can negatively affect local aesthetic and cultural assets, reducing their value and future tourism income potential (Reinfeld 2003; Zomer and Oli 2011). One survey about the impacts of adventure tourism in Hinku Valley in Makalu-Barun National Park, Nepal, showed visitor numbers, lodges, and other tourist-related infrastructure growing rapidly (e.g., from 1 lodge in 1995 to 129 structures in 2007), leading to accelerated harvest of subalpine timber for lodge construction and shrubs for fuel used in alpine tourist lodges (Byers 2014). 


\subsubsection{Mining}

Uncontrolled mining operations also can have detrimental effects on fragile mountain environments, sometimes resulting in large-scale degradation of landscapes and economic crises of sustainability. The impacts of mining on the natural environment and socioeconomic conditions have been studied and documented by several researchers in the region (Huang et al. 2009; IUCN Pakistan 2009; Riaz et al. 2015). Uncontrolled mining practices such as blasting with dynamite have led to vegetation loss, soil erosion, and disturbance to wildlife in Pakistan (Donnelly 2004; Wu et al. 2014a). Coal mining has adversely affected the composition and structure of vegetation in the Nokrek Biosphere Reserve in Meghalaya, India (Sarma and Barik 2011). Large-scale mining, such as in Gyama Valley near Lhasa, China, can impact water quality downstream (Huang et al. 2010). Excessive riverbed mining for gravel and sand in an unplanned, or unregulated manner throughout the Himalaya is also a main reason for, or contributor to, irreparable damage to HKH river ecosystems (Singh et al. 2016).

\subsubsection{Pollution}

In the popular imagination, the HKH is one of the areas in the world least disturbed by human activity, especially by pollution. Nevertheless, studies from recent decades provide a rather different, thought-provoking perspective and the facts are now challenging our traditional thinking (Wu et al. 2016a). As air pollution will be elaborated in Chap. 11, in this section we only summarize the current status and trends, and the potential effects, of water and soil pollution in the $\mathrm{HKH}$.

\subsubsection{Water Pollution: Organic and Inorganic}

Generally, water pollutants - especially inorganic pollutants - have already reached unacceptable levels in some HKH areas (Wu et al. 2016a). Lead (Pb) pollution in several study sites in major river basins including the Salween, Mekong, Yangtze, and Yarlung Tsangpo rivers has been found to be unacceptably high, and magnesium $(\mathrm{Mg})$, aluminium $(\mathrm{Al})$, and iron $(\mathrm{Fe})$ are found in unsafe concentrations (Huang et al. 2008). In Manipur and Diphu, India, concentrations of arsenic (As) in groundwater have already exceeded the permissible limit (Das and Kumar 2015; Devi et al. 2010). Similarly, arsenic contamination is severe in Nawalparasi, Nepal (Gurung et al. 2005) and downstream areas of two major Himalayan rivers in India, the Ganges and Yamuna, are severely contaminated by sewage water containing high concentrations of several heavy metals (Chakarvorty et al. 2015).

Significant variation in water quality is observed in freshwater bodies including ponds, lakes, and rivers, especially on south slopes of the Himalaya. This may be attributed to the multiple sources of pollution including domestic sewage, industrial effluents, and runoff from activities such as agriculture and mining (Najar and Basheer 2012; Rashid et al. 2017). Accelerated eutrophication has been observed in many lakes, including Dal Lake, Khajjiar Lake, Nainital Lake, Anchar Lake, and Khushalsar Lake in India (Amin et al. 2014; Najar and Basheer 2012; Najar and Khan 2012; Rashid et al. 2017; Saini et al. 2008). In Dal Lake, for example, a recent study revealed that it was seriously polluted by chemical fertilizers and pesticides, thus unintentionally nutrient-enriched with concentrations of orthophosphate phosphorous and nitrate-nitrogen reaching 46 and $557 \mu \mathrm{g} / \mathrm{L}$, respectively (Rashid et al. 2017). Pesticide use is generally increasing across the region. For example, pesticide use in India has grown by $750 \%$ since the mid-1900s (Evans et al. 2012). Microbial and organic matter pollution also threaten the health of water systems in the HKH (Merz et al. 2004; Sood et al. 2008; Tong et al. 2016). All of these forms of water pollution threaten aquatic biodiversity, water security, and ultimately human health, on a very large scale through upstream-downstream linkages in regional water systems.

\subsubsection{Solid Waste and Soil Pollution}

Solid waste has increased dramatically in both rural and urban areas of the HKH (Alam et al. 2008). The rapid speed of urbanization also means that treatment of solid waste has become a challenge to the sustainable development of cities. Dangi et al. (2011) reported in Nepal, for example, around $497 \mathrm{~kg}$ per person per day of solid waste is generated from households in Kathmandu Metropolitan City. Although most waste is organic (Dangi et al. 2011; Pokhrel and Viraraghavan 2005), centralized treatment is still very limited because of inadequate capacity or efficiency of facilities. Increasing waste volumes and growing complexity of waste streams, which contain large volumes of hazardous substances, further impact the soils in the $\mathrm{HKH}$ and downstream.

On the Tibetan Plateau, the most common heavy metals in soils are manganese $(\mathrm{Mn})$ and chromium $(\mathrm{Cr})$. The natural concentration of arsenic (As) is also very high at around $20 \mathrm{mg} / \mathrm{kg}$ (Sheng et al. 2012). Along the Qinghai-Tibet railway, Zhang et al. (2012b) found that top-soils in many areas were contaminated by heavy metals in relatively high concentrations, including $\mathrm{Cd}$ and $\mathrm{Zn}$. On the south slope of the Himalaya, very high concentrations of $\mathrm{Zn}, \mathrm{Cd}$, and $\mathrm{Pb}$ were found in the soil of farmlands near Kathmandu (Zhang et al. 2012a). Organochlorine pesticide pollution also has been observed in the soils of Nepal at levels ranging from 20 to $250 \mathrm{ng} / \mathrm{g}$ (Yadav et al. 2016). Above a critical level, all of these substances are toxic to biodiversity including plants and animals, including humans (Osman 2014). 


\subsubsection{Sources of Pollution}

Almost all relevant studies suggest that pollution in the $\mathrm{HKH}$ has become increasingly serious (Box 2.3). The sources of pollutants can be both anthropogenic and natural, but their relative weightings differ across regions (Wu et al. 2016a, b). In remote areas with few or no anthropogenic activities, the pollutants arrive mainly by long-distance atmospheric transport from industrial regions, as well as by the weathering of parent materials (Cong et al. 2010; Sheng et al. 2012; Wu et al. 2016b). Along railways or highways, the fuel from transport vehicles are usually the most significant contributors of pollutants (Zhang et al. 2012a, b, 2013). Overall, in both rural and urban areas of the HKH, most pollution is produced by human activities including the use of pesticides and fertilizers, vehicle traffic, and increased industrial activities (Atreya et al. 2011; Babel et al. 2011; Chakarvorty et al. 2015; Kannel et al. 2011).

\section{Box 2.3 Multiple potential effects of pollution}

Pollution can lead to a series of adverse effects on biodiversity, environment sustainability, and human health. On one hand, some pollutants are shown or predicted to have harmful effects on global biogeochemical cycles, as well as on plant and microbial communities. For example, mercury $(\mathrm{Hg})$ on the Tibetan Plateau may play a critical role in biogeochemical cycles (Loewen et al. 2007). In addition, pollutants will affect different vegetation to varying degrees (Bing et al. 2016), including fragile timberline (Luo et al. 2013; Tang et al. 2015), potentially introducing severe threat to ecological resilience. Furthermore, presence of heavy metals such as copper $(\mathrm{Cu})$, zinc $(\mathrm{Zn})$, lead $(\mathrm{Pb})$ and cadmium $(\mathrm{Cd})$ may lead to the decline of culturable bacteria, actinomyces, ammonifying bacteria, nitrobacteria and cellulolytic bacteria in nature, and thus significantly affect microbial activities (Zhou et al. 2013). On the other hand, pollutants can lead directly to serious human health problems. Heavy metals are usually characterized according to their levels of toxicity, persistence, and bioaccumulation, and are widely recognized as posing severe threats for human health and social sustainability (Cheng 2007; Luo et al. 2015; Nabulo et al. 2010; Wu et al. 2016b). For example, arsenic (As) is a toxic semi-metallic element that can be fatal to humans. The ingestion of inorganic As can result in both cancerous and non-cancerous disorders and can harm the human nervous, dermal, cardiovascular, gastrointestinal, and respiratory systems. Similarly, microbiological contaminations, especially by pathogenic microorganisms, can pose risk to human health (Karkey et al. 2016). Moreover, water pollution may increase the load of waterborne diseases as well as contribute to pollution-induced water shortages, which worsen the water situations in the HKH (Karkey et al. 2016; Schwarzenbach et al. 2010; Zhang et al. 2015a). Restricted access to safe water and improved sanitation, for example, may cause between 15 and $30 \%$ of gastrointestinal diseases, and lead to approximately 1.7 million deaths a year globally [3.1\% of all deaths and $3.7 \%$ of all Disability-Adjusted Life Years (DALYs)] (Ashbolt 2004; World Health Organization 2009). Additionally, a health risk assessment of organochlorine pesticides in the soils of Nepal suggested that exposure through ingestion of soil constitutes one of the most likely pathways leading to increased cancer risk across the country (Amin et al. 2014). Thus, pollution threatens both ecosystem stability and human health.

\subsubsection{Invasive Alien Species (IAS)}

Biological invasion may result not only in the loss of native species but also in an alteration of the extent or quality of ecosystem services and processes (Hulme et al. 2013; Sakai et al. 2001), which in turn may have drastic negative economic consequences (Pimentel et al. 2001). Direct costs of such invasions include losses due to reduced productivity in agroecosystems, whereas indirect costs are accrued in combating invasive species. Many IAS found in the $\mathrm{HKH}$ are included within a list of the world's 100 most harmful or damaging IAS (Lowe et al. 2000), such as Eichhornia crassipes, Lantana camara, Chomolaena odorata, and Mikania micrantha. Many other IAS also pose serious environmental problems and challenges to regional efforts to conserve the environment and to meet sustainable development targets.

\subsubsection{Status of IAS Studies in HKH}

There are few studies of IAS in the HKH. Most studies focus on basic inventories and ecological studies of invasive alien plant species (Akter and Zuberi 2009; Khuroo et al. 2007; Kosaka et al. 2010; Qureshi et al. 2014; Tiwari et al. 2005; Weber et al. 2008). Only several studies have focused on invasive alien fauna species (Budha 2015; Sujoy et al. 2010; Wan and Yang 2016).

In Nepal, inventory and assessment work carried out by IUCN Nepal has identified 166 naturalized plant species, of which 25 are recognized as invasive (Shrestha 2016; Tiwari et al. 2005). Recent inventory work carried out in the 'Kailash Sacred Landscape' in western Nepal has specifically noted 15 plant IAS (Bisht et al. 2016; Shrestha et al. 2018). In terms of fauna IAS, 64 species have been reported 
in Nepal, including 7 mammals, 6 birds, 19 fish, 22 arthropods, 9 molluscs, and one platyhelminth flatworm (Budha 2015).

In Pakistan, Qureshi et al. (2014) have listed 73 species of IAS including many that also are widespread and invasive in other parts of the world, such as Broussonetia papyrifera, Prosopis juliflora, Parthenium hysterophorus, and L. camara. All were reported as high-impact invasive land plants. Bhattarai et al. (2014) also reported that the diversity (species richness) of naturalized plant species increased with elevation up to $1100 \mathrm{~m}$ asl, and then decreased with further gains in altitude.

Elsewhere, Sekar (2012) identified 190 IAS in 47 families and 112 genera distributed across the Indian Himalaya. A recent survey by $\mathrm{Xu}$ et al. (2012) identified 488 IAS in China, with the highest number reported from Yunnan Province, but the exact number of IAS distributed in the Chinese Himalaya could not be confirmed. There is limited information about IAS in Afghanistan, Bhutan, and Myanmar.

\subsubsection{Pathways of Introduction}

A basic understanding of the major dimensions of introduction pathways of alien plants is important for regulating their invasions (Pyšek et al. 2011). Some studies have provided evidence that recent infrastructure developments, particularly the construction of roads, has greatly facilitated invasions and provided both habitat and potential dispersal corridors for exotic plant species in mountainous regions of China, India, and Nepal (Bhattarai et al. 2014; Chen et al. 2012; Kosaka et al. 2010; Xu et al. 2012). Similarly, natural and anthropogenic disturbances (such as recreational hiking) might act together to facilitate both the introduction and spread of exotic species, putting the ecosystems of the region at higher risk of invasion and consequent damage or loss (Dar et al. 2015; Dobhal et al. 2011).

Another major dispersal pathway for many IAS in the $\mathrm{HKH}$ is international trade and human movement (Tiwari et al. 2005; Xu et al. 2012). Agricultural inputs, particularly seed stocks originating outside the community, are another source of invasion (Kunwar 2003). Lack of adequate mechanisms to search for IAS and a poor quarantine system render the region vulnerable to the threat of IAS.

\subsubsection{Major Effects at Ecosystem Level}

Among few studies of IAS in the HKH, most focus primarily on IAS status (Barua et al. 2001; Khuroo et al. 2012; Reshi and Khuroo 2012) and distribution patterns (Bhattarai et al. 2014; Khuroo et al. 2010, 2011; Sang et al. 2010; Shabbir and Bajwa 2006). The overall impact of IAS in the HKH has not been properly studied; however, some adverse environmental impacts have been noted, such as the alteration in habitat and species composition that have been experienced through the aggressively invasive character of some species within some of the region's ecosystems (Dobhal et al. 2011; Dogra et al. 2009; Kunwar and Acharya 2013; Reshi et al. 2008). Moreover, the abundance of some IAS species has led to ecological displacement of native species and caused negative impacts on local livelihoods (Rai and Rai 2013; Rai and Scarborough 2015). P. hysterophorus, sometimes known as carrot grass, is perhaps the most troublesome and noxious weed in forest, pasture, wasteland and cultivated areas resulting in health-related issues in both humans and livestock (Kohli et al. 2006; Rashid et al. 2014).

Invasive shrubs and vines also pose a major threat to forest ecosystems, having a negative impact on their regeneration, structure, ecosystem functions, recreation opportunities, and wildlife habitat. Increased abundance of the unpalatable L. camara, for example, has suppressed regeneration of a number of native species, with detrimental demographic consequences for several important NTFP species in India and Pakistan (Dogra et al. 2009; Dobhal et al. 2010, 2011; Kannan et al. 2013; Kohli et al. 2006; Rashid et al. 2014). In Chitwan National Park, Nepal, M. micrantha has invaded vital habitat for the world's largest population of the great one-horned rhinoceros, destroying preferred wildlife habitat as well as jungle hiking trails.

In farming systems, $M$. micrantha also has suppressed the growth and yield of a variety of food and cash crops (Shen et al. 2013, 2015). The invasive plant Ageratum conyzoides equally invades agricultural fields (where it interferes with and causes yield reductions in major staple crops) and rangelands (where it outcompetes native grasses, causing scarcity of fodder) (Kohli et al. 2006).

In aquatic ecosystems, the rapid increase and spread of invasive plants also is a common phenomenon, creating great ecological and economic problems in the region (Akter and Zuberi 2009; Masoodi and Khan 2012; Wang et al. 2016; $\mathrm{Xu}$ et al. 2006). For example, E. crassipes blocks waterways, threatening biodiversity in Ramsar sites and damaging people's livelihoods in many other lake systems by hindering boat traffic and restricting fishing opportunities, with consequent economic losses (Burlakoti and Karmacharya 2004; Ding et al. 2008; Wang et al. 2016). Economically valuable native freshwater fish in India, Nepal, and Pakistan also are under threat from invasive alien fish species such as tilapia (Husen 2014; Khan et al. 2011).

\subsubsection{Mountain Hazards}

\subsubsection{Types of Mountain Hazards: Earthquakes, Landslides, and Erosion}

Mountain regions are high-risk areas, where hazards can cause damage, destruction, injury, and death at any time. 
Compared with many other mountain areas of the world, in the HKH hazards are likely to be more severe as the region consists of young mountains that are still growing, making it inherently more vulnerable to earthquakes, landslides, and erosion. Every year there are on average 76 hazard events in the HKH, with the highest number noted in China (25) and India (18) (Nibanupudi and Rawat 2012).

As the HKH is located in tectonically active zones, its susceptibility to earthquakes is higher than in lowland areas. The 1934 Nepal-Bihar earthquake in Nepal $\left(M_{w}=8.0\right)$, the 2005 Kashmir earthquake in Pakistan $\left(M_{w}=7.6\right)$, the 2008 Wenchuan earthquake in China $\left(\mathrm{M}_{\mathrm{w}}=7.9\right)$, and the 2015 Gorkha earthquake in Nepal $\left(\mathrm{M}_{\mathrm{w}}=7.8\right)$ all led to huge losses of life and property, and also triggered vegetation degradation, landslides, rockfalls, and soil erosion (Lu et al. 2012; Ministry of Science, Technology and Environment, Government of Nepal 2015). There is growing scientific consensus globally that a disproportionally high number of natural disasters occur in mountain areas, and that these regions have become increasingly prone to disasters in recent decades (Guha-Sapir et al. 2016; Pathak et al. 2010). In addition, following earthquakes, a variety of mountain hazards including landslide, debris flow, and dam burst floods are more likely to occur over the ensuing one or two decades (Cui et al. 2008).

\subsubsection{Effects of Mountain Hazards: Casualties, Financial Loss, Farmland Loss, Damaged Roads}

Mountain hazards can cause many human casualties and incur huge economic losses for a region, often constraining economic development for many years following events (Zhang et al. 2016). In Nepal, it is estimated that landslides, floods, and avalanches destroy important infrastructure at an annual cost of around USD 9 million, and causing about 300 deaths per year (DWIDP 2005). In Afghanistan, 362 people were killed or reported missing, 192 injured, and 100,000 displaced as a consequence of flash floods in 2005 (Xue et al. 2009). The annual economic losses caused by landslide hazards in the Himalayan area is estimated at more than USD 1 billion, which is about $30 \%$ of the total economic losses caused by landslides worldwide ( $\mathrm{Li}$ 1990).

The constraints of mountain topography mean that most residential regions are located in valleys where flatter and more accessible lands are found. These areas are at high risk of landslides, debris flows, and flooding. Similarly, arable land is very limited in mountainous regions because of constraints of terrain; most farmland is reclaimed land on terraced slopes or along rivers and on alluvial fans. Although necessary for most farming, irrigation also increases soil moisture and changes the stability of slopes, thus leading to increased risk of sliding or collapse of terraced slopes, or of being buried at the foot of slopes.
Road construction in general is a large and complicated endeavour, which must always consider and respond to different geomorphologic and geologic conditions. Construction projects are often at risk from different kinds of geohazards. Road construction introduces high fills, high-cutting slopes, and waste, which disturb the geologic environment along the road and compromise the stability of hill slopes. Even when landslides occur only at one or a few points along the road, they can destroy or block entire sections of road and affect much larger transportation networks and connections. For instance, the Sun Koshi landslide, which occurred in Nepal on 2 August 2014, destroyed the Araniko Highway for only a short distance $(2 \mathrm{~km})$. As a result, however, the entire highway - a major trade link between China and Nepal with trade exchange of nearly NPR 38 million (nearly USD 370,000) per day-was blocked for almost 2 months (Zhang et al. 2017).

Various other forms of damage from natural hazards occur as well. For example, tourism is affected by mountain hazards in several ways. Both the natural and cultural landscapes may be damaged or destroyed, including ancient architectural monuments, which may be difficult to recover or rebuild. Mountain hazards can also damage the infrastructure in scenic areas (including transport routes, communication lines, and accommodation); thus the numbers of tourists that can visit an area may be reduced dramatically as a result. The 2015 Gorkha Earthquake in Nepal caused damages and losses to tourism in the amount of NPR 81,242 million (nearly USD 790 million). It is estimated that the number of tourists decreased by $40 \%$ in the first year following the earthquake, though is likely to have recovered back to $80 \%$ of pre-earthquake numbers in the second year after the earthquake. The overall loss of direct tourism revenue was estimated to be over NPR 47 billion (nearly USD 456 million) from the time of the earthquake to March 2016. A broader accounting of losses in tourism income, including air transport, trekking, tour operations, restaurants, and the costs of debris removal, has estimated tourism-related losses to have amounted to NPR 62.4 billion (nearly USD 606 million) (SafeNEPAL 2016). Similarly, it is estimated that the Jiuzhaigou earthquake in August 2017 in Sichuan, China, which resulted in the temporary closure of Jiuzhaigou National Park, led to the loss of direct tourism revenue in the millions of USD and damage of natural scenic landscapes including forests, lakes and waterfalls (China News Service 2017).

\subsubsection{Impact of Mountain Hazards Amplified by Climate Change}

The frequency and magnitude of mountain hazards will increase under the impact of climate change; and in combination with growth in the population and economy, the risk of mountain hazards will increase dramatically (Cui et al. 2014). For the HKH, climate change is very likely to 
strongly impact the hydrological cycle, which is predicted to alter rainfall patterns and intensity, as well as the frequency of extreme precipitation events. Extreme rainfall is generally believed to trigger mountain hazards. For example, changing monsoon patterns in South Asia, including increased severity and frequency of storms as projected by climate models, may not only directly threaten agricultural production and the livelihoods of millions of people, but could also destroy critical infrastructure by way of mountain hazards induced by storms (Moors and Stoffel 2013). Increased water flows accelerate river erosion by destabilizing valley slopes, with dramatic effects where slopes are saturated with water after prolonged intense rains, and sediment is then deposited elsewhere. In addition to causing sediment transfer and deposition elsewhere, riverbank erosion changes stream channel morphology and can easily lead to cascading hazards in mountain areas and beyond (Cui et al. 2014).

For its part, global warming reduces snow cover, melts glaciers, and degrades permafrost. Related biophysical systems are thus being affected through enlargement and increased number of glacial lakes, increasing ground instability in permafrost regions, and rock avalanches (Pathak et al. 2010). Glacial lake outburst floods (GLOFs) result in numerous casualties and property damage in the HKH. An investigation in 1999 and 2005 by ICIMOD and its partners showed that there were 8790 glacial lakes covering a total of $801.83 \mathrm{~km}^{2}$ in the $\mathrm{HKH}$, of which 203 lakes were potentially dangerous and could pose a GLOF threat in the future (Ives et al. 2010). As vegetation development is a slow process at such high altitudes, these sites may remain unprotected against erosion for decades or even centuries (Fusun et al. 2013). Landslides and debris flows thus pose long-term threats to settlement and infrastructure in many places.

\subsubsection{Climate Change and Variability}

As a key driver of changes in mountain sustainability today, climate change is interacting in complicated ways with many other important drivers-globalization, population growth, urban expansion, and local land use change - all of which can have significant ramifications (see Chap. 3 for full details). Climate change has environmental and social impacts that are likely to increase uncertainty in water supplies and agricultural production for human populations across the HKH. Changes in temperature and precipitation could have serious implications for biodiversity and the goods and services derived from ecosystems (Chettri and Sharma 2016). Climate warming is leading to visible effects in the $\mathrm{HKH}$, with indications of changes in phenology, and with reduced agriculture production in some of the major crops in some parts of the HKH (Hart et al. 2014; Webb and Stokes 2012).

\subsubsection{Environmental Effects}

Our discussion of primary impacts and hazards associated with climate change in the HKH-changes in hydrology, permafrost, and mountain environments-will summarize studies embodying a wider range of climate scenarios and projection. Observed climate changes in the HKH (especially higher regional temperatures) have already affected biological and ecological systems directly and indirectly, coupling with other anthropogenic drivers. Hydrological processes are also altered by climate change, which as a result lead to change in carbon sequestration and nitrogen deposition, as well as in human livelihoods and consumption (Singh et al. 2011).

\section{Hydrology}

Changes in hydrology can impose great challenges to human society and natural ecosystems (see Chaps. 3, 7 and 8 for full details). Glaciers in the HKH have been retreating continuously since the 1970s, with an accelerating rate of retreat in the past decades (Bajracharya et al. 2011; Ding et al. 2006; Fujita et al. 2008; Pu et al. 2004; Takeuchi et al. 2009; Yao et al. 2007). Upstream snow and ice reserves in the HKH have been affected substantially by climate change (ICIMOD 2011; Shrestha and Aryal 2011). River discharge is likely to increase for some time because of accelerated melting, which indirectly affects the water availability and food security of large human populations (Immerzeel et al. 2010; Nepal and Shrestha 2015). On the Tibetan Plateau, for example, glacial retreat has caused hydrological changes, including river runoff increasing over $5.5 \%$ (Yao et al. 2007), and the water level of most lakes rising by up to $0.2 \mathrm{~m} \mathrm{yr}^{-1}$ (Zhang et al. 2011), accompanied by surface expansion of many lakes (Liu et al. 2009, 2010). Thorough analysis of the impacts of climate change on future water availability in these basins is thus needed, and could immediately affect climate change policies where transition towards coping with intra-annual shifts in water availability is desirable (Lutz et al. 2014).

\section{Permafrost}

The potential impacts of thawing permafrost (see Chap. 7 for full details) remain largely unknown for most of the HKH (Valério et al. 2008). The extensive permafrost is highly sensitive to temperature changes, resulting in significant warming, thawing, thinning, and retreat throughout the $\mathrm{HKH}$ in recent decades, especially on the Tibetan Plateau (Yang et al. 2010). Long-term temperature measurements have indicated that the lower altitudinal limit of the permafrost has moved upwards by $25 \mathrm{~m}$ at Xidatan in the interior of the plateau during the last 30 years and upwards by $50-80 \mathrm{~m}$ 
along the Qinghai-Kang Highway, located on the eastern edge of the plateau, over the last 20 years (Cheng and $\mathrm{Wu}$ 2007). In the Khumbu (Everest) Himalaya, apparently the permafrost lower limit has risen 100-300 m between 1973 and 1991, then stabilized at least until 2004 (Fukui et al. 2007).

\section{Mountain-specific environments}

Mountain environments, in particular the $\mathrm{HKH}$, are potentially vulnerable to the impacts of global warming because the combination of high sensitivity to climate change and limited possibilities for species migration to favourable locations renders mountains as "islands" in a "sea" of surrounding lower-lying ecosystems (Busby 1988; Frey et al. 2011; Shrestha et al. 2012). In the high-altitude regions of the HKH, glacial melt is affecting hundreds of millions of rural dwellers who depend on the seasonal flow of water, with more water available in the short term but less in the long run as glaciers and snow cover shrink and disappear. In Nepal, data from 1980 to 2015 show that floods, landslides, and epidemics were the main causes of disaster-related human loss (Carpenter and Grünewald 2016). Many recorded GLOFs in this region have caused severe socioeconomic damage (Hasnain 2007; Richardson and Reynolds 2000). Many risk assessment studies recently carried out in the Himalaya have identified ice avalanches from advanced glacier tongues and ablation of dead ice beneath moraine ridges as potential GLOF triggers (Bolch et al. 2008; Fujita et al. 2008; ICIMOD 2011; Watanabe et al. 2009).

Climate change has synergistic effects with many of the other primary threats or constraints to biodiversity. With enhanced temperature and reduced precipitation, for example, alpine meadows and shrubs may migrate to places higher up the mountains. However, this process will be constrained by environments that do not have soils of sufficient depth for anchorage and nutrient storage. Grabherr et al. (1994) estimated that a $0.5{ }^{\circ} \mathrm{C}$ rise in temperature per $100 \mathrm{~m}$ elevation could lead to a theoretical shift in altitudinal vegetation belts of $8-10 \mathrm{~m}$ per decade (Grabherr et al. 1994). In the eastern Himalaya, this altitudinal shift is expected to be around $20-80 \mathrm{~m}$ per decade (based on current estimates of temperature increases of around $0.01-0.04{ }^{\circ} \mathrm{C}$ per year) with greater shifts at higher altitudes, as the rate of warming is expected to increase with altitude (ICIMOD 2009). Wetlands will shrink in response to high evaporation, which will be further exacerbated by the expansion of settlements and other human activities. The rising temperature of water bodies renders them more suitable as habitats for invasive species that outcompete native species and synergistically interact with climate change to threaten native organisms (see Sect. 2.2.4).

\subsubsection{Socioeconomic Effects}

Coupled with social, economic, and political stresses, climate change could have serious cascading effects with potentially catastrophic consequences, including adverse impacts on ecosystem services supply, as well as on the agricultural productivity, human health, and livelihoods of the millions of people living in the region (Ariza et al. 2013) - particularly where they are dependent upon natural resources (Rautela and Karki 2015). Declining natural resource availability and uncertainty introduced by climatic variability pose a threat to mountain sustainability in the face of an already declining natural resource base.

\section{Agriculture}

Agriculture is the direct or indirect source of livelihood for over $70 \%$ of the population of the HKH, and a substantial contributor to national incomes (Tiwari 2000). Changing precipitation patterns, reduced runoff in the major river basins, and increasing temperatures will simultaneously put additional pressure on available water resources and increase agricultural water demand for rainfed and irrigated crops, thus increasing competition for water for agriculture, industry, and human consumption (Hanjra and Qureshi 2010). Agriculture in this region is mostly rainfed (about 60\%; World Bank 2016) and therefore vulnerable to changes in timing and frequency of precipitation. Besides water availability, crop yield depends on a number of biophysical processes and variables (such as thermal stress, humidity, solar radiation, nitrogen stress, ozone, and the fertilization effect of $\mathrm{CO}_{2}$ ) and their complex, nonlinear interactions (Challinor et al. 2009). Extremes in floods and droughts through much of the upcoming century may destroy the food production base of the region (Bruinsma 2003). Fischer et al. (2002) expected a temperature increase of $1.5-2.5^{\circ} \mathrm{C}$ to lead to a decline in the agricultural productivity of crops such as rice, maize, and wheat. Climate changes are predicted to reduce the livelihood assets of rural people, alter the path and rate of national economic growth, and undermine regional food security due to changes in natural systems and impacts on infrastructure.

\section{Human wellbeing}

Climate change affects the environment as well as social and economic developments in the region. It exacerbates the difficulties already faced by vulnerable indigenous communities, including political and economic marginalization, loss of land and resources, human rights violations, discrimination, and unemployment (Chavez et al. 2014). The consequences of biodiversity loss from climate change are likely to be worst for the poor and marginalized people who 
depend almost exclusively on natural resources. Poverty, poor infrastructure (roads, electricity, water supply, education and health care services, communication, and irrigation), reliance on subsistence farming and forest products for livelihoods, substandard health (high infant mortality rate and low life expectancy), and other aspects of development, render the HKH even more vulnerable to climate change as the capacity to adapt is inadequate among the inhabitants (Manandhar et al. 2018, Negi et al. 2012).

Furthermore, climate change, land use transition, and environmental migration in the HKH have impacts on social relations between nations, social classes, ethnic groups, and individual families as they increasingly struggle for access to essential resources. This combination is a significant source of potential as well as actual violent conflicts (Agnew 2011; Aryad et al. 2013; Bhusal and Subedi 2014; Hsiang et al. 2011). The impacts on human health are similar (Sharma 2012), as most emerging human diseases are driven by human activities that modify ecosystems or otherwise spread pathogens into new ecological niches (Taylor et al. 2001). Such modifications or alterations in ecosystems generally lead to large-scale land degradation, changing the ecology of the diseases that influence human health and making people more vulnerable to infections (Collins 2001). Decisions about change of land use, whether in response to climate change or other factors, are thus also human health decisions (Xu et al. 2008).

\section{Migration}

Yet another threat to human wellbeing is "forced environmental migration" of populations that can occur as a result of environmental phenomena caused by changes in the Earth's climate (Ramos et al. 2016). In some instances, rural farmers migrate to the city and there are consequent labour shortages in rural areas, leading to socioeconomic difficulties in the rural agroeconomy (Sann Oo 2016). However, livelihoods in the Himalaya have traditionally depended on a multitude of strategies, including available ecosystem goods and services, but typically also encompassing external activities such as trade and labour migration. Yet changes in ecosystem services following environmental or socioeconomic change will clearly affect mountain livelihoods, and therefore are likely to impact migration numbers and patterns (Banerjee et al. 2014). If the incidence and magnitude of extreme events such as droughts and floods increase, there could be large-scale demographic movements and ultimately transformation. The annual rate of increase in migration in the countries of the HKH has been disturbingly high, and the number of internally displaced people also is expected to rise significantly.

\subsection{Sociocultural Drivers of Change to Mountain Sustainability}

\subsubsection{Changing Demographic Situation}

Demographic processes such as population growth and decline, changes in age distribution and education, social and spatial mobility (migration), and concentration of activities at market-based cities and local centres (urbanization) are the result of environmental and economic drivers and exert impacts on both. In environmental terms, demographic oscillations increase the demand and consumption of natural resources, and change land use, with the risk of degradation by overuse or underuse. In socioeconomic terms, demographic changes contribute to the transformation of social relations and structural changes in mountain economies. In either case, the changing demographic situation has both quantitative and qualitative impacts.

Sociodemographic changes are in turn affected by a range of factors such as technological innovation, institutional and financial conditions, and climate change. The availability and quality of natural resources, as well as trends in their exploitation, can equally influence demographic processes. The biophysical environment has two functions for human beings: it guarantees their physical existence and livelihoods and is at the same time a resource for economic activities and exchange in a given (and transforming) society. The combination of these two functions generates a continuous tension between use and preservation and defines the human impact on the environment. This is important for the question whether mountains should mainly serve for its inhabiting population or for the downstream consumers and global visitors. Thus, the number of humans, population growth rates, and especially the population distribution are good proxies both of the pressures that human communities face and that they are placing on the Earth. The sociodemographic and environmental interdependencies are complex and remain poorly understood (DeSherbinin et al. 2007). For example, rapid population growth and poverty are often blamed as being the main twin causes of deforestation, yet recent large-scale deforestation in South Asia is largely driven by agricultural enterprises and accompanying road construction along with local and regional migration (DeFries et al. 2010; Rudel et al. 2009).

The total population in the mountains and hills of the HKH region was approximately 225 million in 2015 (United Nations 2015b). Of the eight member countries, India has the highest population distributed within the HKH (50.31 million), followed by Bangladesh (45.55 million), Afghanistan (33.33 million), Pakistan (32.16 million), Nepal (28.83 million), China (20.48 million), Myanmar (13.32 


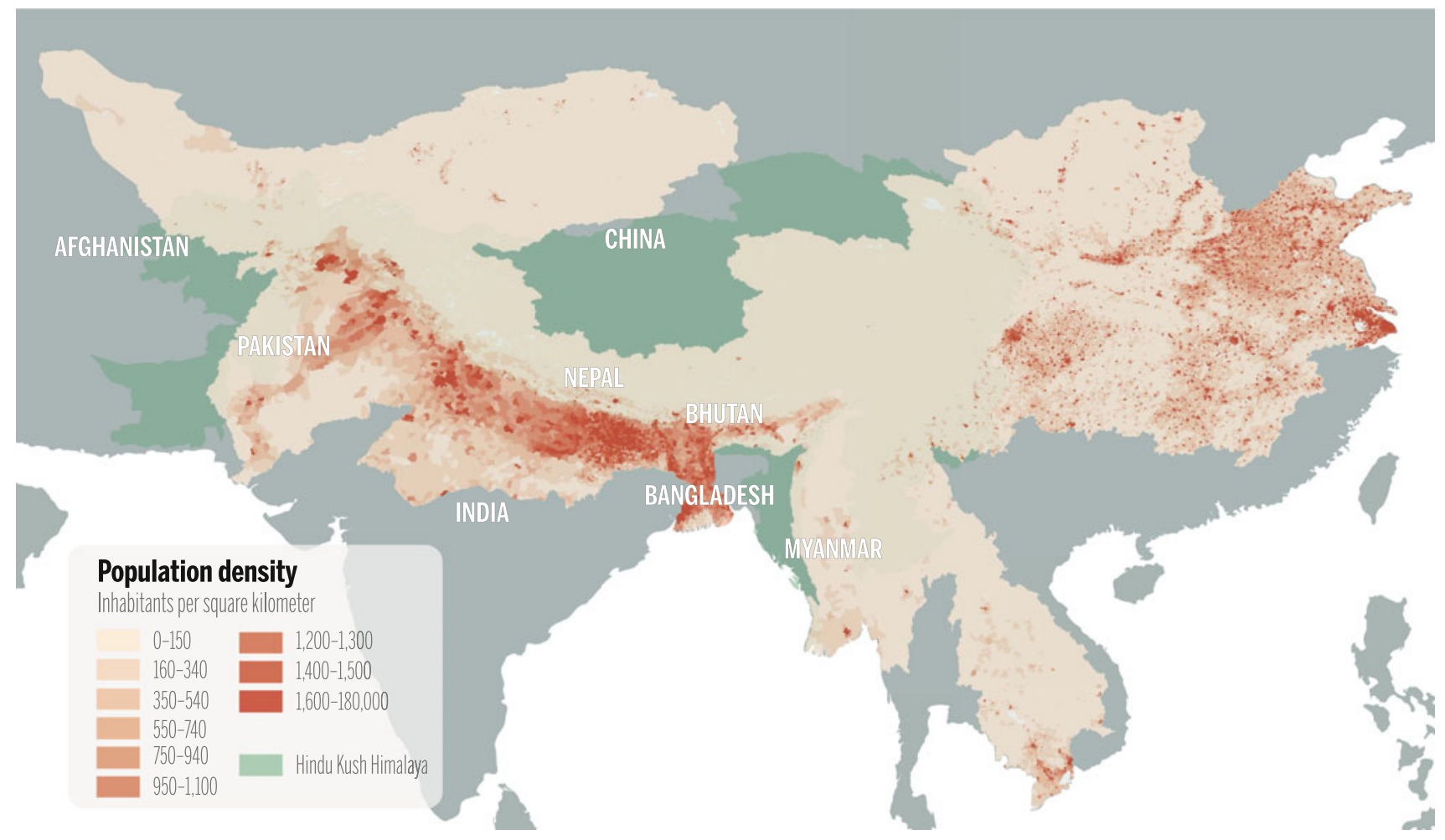

Fig. 2.3 Population density in the $\mathrm{HKH}$

million), and Bhutan (0.78 million). Although China is the most populated country in the world, its HKH population (mainly on the Tibetan Plateau) is much less because of the high altitude and harsh environment with limited agricultural opportunities. Population is most dense along the southern fringe of the HKH including Nepal and India, the Chittagong hill tracts in Bangladesh, and the upper Indus Basin in Pakistan (see Fig. 2.3).

Almost all countries/territories in the region have experienced a steep decline in fertility in recent decades, which has resulted in a lower rate of population growth (World Bank 2015). The mean annual growth rate of most regional countries in 2015 ranged between $1 \%$ and $2 \%$, but was higher in Afghanistan (2.8\%) and Pakistan (2.1\%) and lower in China $(0.5 \%)$ and Myanmar (0.9\%) (United Nations 2015a). During the period from 1960 to 2014, the total fertility rate (births per woman) declined, with the lowest in China (1.6) and the highest in Afghanistan (4.8) and Pakistan (3.6), and the other countries with a total fertility rate of between two and three children (World Bank 2015). Conscious efforts to limit fertility through increased knowledge about contraception, together with decreasing infant mortality, are important factors in controlling high fertility rates (United Nations 2003). Conversely, life expectancy at birth within the eight regional countries rose remarkably in recent decades, exceeding 70 years in China (76), Bangladesh (72), and Nepal (70) and reaching nearly 70 years in Bhutan (69), India (68), and
Pakistan (66) ${ }^{1}$; Afghanistan has the lowest life expectancy (60 years). However, it should be noted that, in 1960, life expectancy in none of the eight countries exceeded 50 years. Compared to the global average, people in developing countries normally have shorter lives (United Nations 2012). To a certain extent the observed changes in life expectancy at birth are partial indicators of improving socioeconomic development in this region.

Although the population of the HKH is mostly rural, the urban population increased rapidly in the last three decades due to processes of urbanization, industrialization, and ruralurban migration. The urban population in China rose from 16 to $56 \%$ during the period from 1960 to 2014 (United Nations 2014). In 2014 all other countries in the region had a similar percentage - between $30 \%$ and $40 \%$ - except Nepal (19\%) and Afghanistan (27\%) (United Nations 2014). While the regional urban population grew rapidly during the 20th century, the next few decades will see an unprecedented scale of urban growth, putting more pressure on land cover, natural resources, ecosystem services, and social services. In most established or formal urban areas, access to water supply and sanitation services is believed to be better than in rural areas. In some peri-urban areas, however, residents have little access to safe drinking water or adequate

\footnotetext{
${ }^{1}$ See: https://data.worldbank.org/indicator/SP.DYN.LE00.IN.
} 
sanitation services, increasing the danger of water- and sanitation-related diseases (United Nations 2014; World Water Assessment Programme 2009).

In terms of age dependency ratios (i.e., percentage of working-age population), Afghanistan (87\%), Pakistan $(65 \%)$, and Nepal (62\%) are ranked at the top, with China at the bottom (37\%). This indicates that larger workforces could be provided in these countries if better educational opportunities were available. Rapid population growth, combined with economic difficulties, pushes people to cities. A declining and ageing population induces countries or regions to accept migrants, who are typically willing to work at much lower wages than native workers (Hoermann and Kollmair 2009). The net implication of these demographic processes is clear: the HKH will have substantially more people in vulnerable urban areas in the next 20 years. The migration from rural to urban areas also results in consumption and dietary changes, which may further contribute to increased pressures on many ecosystems (de Sherbinin et al. 2007; Dietz et al. 2007; Romanelli et al. 2015; Tilman et al. 2005; see Sect. 2.4.3 'Urban and peri-urban expansion' in this chapter).

In the HKH, migratory populations include traditional groups of subsistence-level pastoralists and agriculturalists, as well as family groups and individuals seeking greater opportunities and refugees fleeing the consequences of armed conflict or natural disasters (Hoermann and Kollmair 2009; Tiwari and Joshi 2015). People who have become new refugees because of wars, in particular, often pass through camps or informal settlements, leading to the proliferation of informal communities on the fringes of cities (UNHCR 2015). In these situations the arrival of additional people may exacerbate resource scarcity (e.g., water and agricultural land), strain the capacity of the urban infrastructure, and even result in conflicts with local communities. It is believed that climate change, which is predicted to lead to greater frequency and intensity of extreme weather events, is likely to result in increased migration and possibly to an overall increase in the displacement of people in the future (Tiwari and Joshi 2015).

\subsubsection{Changing Sociocultural Situation}

Cultural drivers of change have existed in the HKH for as long as cultural communities have inhabited the region. Some scholars (Cordaux et al. 2004; Gayden et al. 2007) have understood the HKH to be a great, fixed geographical barrier impeding or restricting the flow of human gene pools (Box 2.4). However, viewing the HKH from a historical/cultural lens, it could be found that the strategic location of this formidable mountain chain is at the intersection of South Asia, East Asia, and Central Asia as a facilitator for the historic emergence of distinct cultural and politico-economic groups.

\section{Box 2.4 Culture as a driver}

Culture can be broadly defined as the way a community lives at a certain point in time (Kalman 2009). Culture shapes people's perceptions, judgments, ideas of self and other, and human relationships (LeBaron 2003). To apprehend culture, one has to look at the way living is "performed"-by articulations of shared as well as contested ideas, beliefs, and values through the ways in which relationships between people as well as between people and "things" manifest themselves via practices and representations - at levels both "mundane" and "out of the ordinary" (Kien 2009). In discussing the cultural drivers of change in the HKH, a critical element to highlight is that while culture itself is always in the making, in the process "culture" also affects or changes its own members or participants. New forms of articulations and practices indicate emerging aspirations, desires, capabilities, and forms of resistance among the culture's participants. At the same time, such changes can engender or encourage physical movements of its participants to and away from a particular location. This can be seen, for example, in the phenomenon of rural-to-urban and hills-to-plains migration, wherein changing value systems and agents of modernity effect dislocation. The effects of this process of cultural change can happen in multiple places simultaneously, or more gradually and unevenly. These changes also can affect the ways in which people relate to the surrounding natural landscapes.

Such people and groupings, traditionally reliant largely on locally adapted forms of agropastoralism and trade, generally have deep interdependence with distant populations and societies located on either side of the mountain chain (Bauer 2004; Fürer-Haimendorf 1975; Olschak et al. 1987). For example, among the many Tibeto-Burman cultural and ethnolinguistic communities spread across the $\mathrm{HKH}$, the local material cultures and political economies grew for several centuries in the midst of a complex web of interdependence, with much larger cultural and political spheres extending both to the north and the south of the Himalaya (Gerwin and Bergmann 2012; Shakya 1999). This growth of cultural communities in the HKH was essentially premised upon interactions and movements of people; items of trade, religion, art and folk cultures; and emerging political formations (Cacopardo and Cacopardo 2001; Handa 2001). Such interactions, with cultures, technologies, and polities outside the HKH, have always been the critical cultural drivers of change within the HKH.

However, the pace of changes in the materiality, values and aspirations, and social relations (i.e., the key effects of 
cultural drivers) among the communities of the HKH has accelerated exponentially since the 20th century. Throughout the region, the 20th century was a period of great political, economic, social, and cultural transformation. It saw the emergence of nation states all over Asia and, with that, the bid to integrate peripheral regions such as those of the HKH into national mainstreams (Bose and Jalal 2004; McCauley 2016). In the last three decades, globalization has also been making deep inroads into the HKH, facilitated by liberalizing economies, better connectivity, and transnational flows of media and tourism (Bauer 2004; Hodge 1991; Hodges et al. 2014; Jodha 2005). At the same time, fluid movements and long-standing relations between borderland communities for trade, pilgrimage, pastoralism, and often also kinship became more and more constricted because of the tightening of borders, and in many places they eventually became completely cut off from one another (Bauer 2004; Harris 2013; Hoon 1996).

Overall, increased connectivity, increasing penetration by the state and markets, geopolitical developments, globalization, and the spread of new technologies have engendered many new kinds of interactions, imaginations, aspirations, and practices in the communities of the HKH. Just as in the past, these processes of interaction between the local community and the world beyond form the cultural drivers of change. Numerous studies from the HKH show that these processes occur in deeply intertwined ways and are heavily interdependent, and thus need to be studied together. Hodge (1991), Kreutzmann (1993, 2004), Banskota et al. (2000), Aggarwal (2004), Bauer (2004, 2005), Bergmann et al. (2008), Ueda and Samdup (2010), Demenge (2012), Harris (2013), Howard (2013), Toffin and Pfaff-Czarnecka (2014), and Grocke (2016) are some good, in-depth studies laying in sharp relief the complex, material ways in which members of various HKH communities experience, contest, and negotiate interactions with the aforementioned agents of change.

The establishment and growth of state-supported institutions of local governance and the implementation of state policies - on sectors ranging from education to health care, natural resource management to primary infrastructure development-are fundamentally contingent upon the improvement of connectivity of these rugged regions, both in terms of physical access and communication technology. Additionally, connectivity has also been to shown to link these mountain communities to national, regional, and global flows of commerce, media, consumptive choices, labour, and tourism (IUCN 2017). As connectivity, the reach of state apparatus, and globalization increase, they cause significant changes in the realms of (1) social relations between different strata of communities, (2) traditional livelihoods and their relation to the local and broader socioecological systems, and (3) power dynamics in terms of gender, social background, and age among community members.
It may be futile, though, to attempt to label the effects of cultural drivers of change in the HKH as completely positive or negative. The interactions enabled by enhanced connectivity occur in the "sticky materiality" of pre-existing socioecological landscapes and thereby have "awkward, unequal, unstable, and creative" effects, often in unintended ways (Tsing 2005). There have been some unquestionably positive developments in many cases, such as improving access to education and general health care, new livelihood opportunities, breaking down of oppressive traditional hierarchies, and improved awareness and practices around maternal health and sanitation. However, the sociocultural drivers of change have also brought in their wake developments such as the loss of traditional knowledge and folk art forms, haphazard road and building construction, breakdown of traditional sociopsychological support systems in the face of difficult times, and a growing sense of alienation (Foggin 2016). With the increasing spread of connectivity, governmentality, and globalization, many parts of the HKH have also faced increasingly volatile and sometimes violent geopolitical conditions over recent decades (Agrawal et al. 2016; ICIMOD 2012). There is therefore a need to create locally sensitive modes of development that help to empower local communities to make decisions regarding their lifeworld, while respecting the opportunities and limitations imposed by the geoclimatically diverse landscapes of the HKH (Hodges et al. 2014).

\subsubsection{Governance Systems and Institutions}

Mountain areas of the HKH have not remained isolated from development interventions brought in by government and non-government agencies. At the same time, the region has experienced environmental degradation with resulting socioeconomic problems such as water scarcity, crop depredation, and scarcity of fuelwood and fodder. Moreover, this has happened in the last few years despite growing awareness of the importance of maintaining environmental health, especially in mountains. The question that needs to be asked is: what led to this situation? Is it wrong policy adopted by central and provincial governments? Is it changing developmental aspirations of people? Is it the failure of traditional institutions that regulated the use of environmental goods and services until recently, or the failure of modern institutions that replaced them to maintain sustainability? Some scholars feel that it is likely due to a failure of development agencies to consider interventions from a "mountain perspective" (Ives 2013; Price 2015) especially in regard to inaccessibility, marginality, fragility, diversity or heterogeneity, niche or comparative advantage, and human adaptation mechanisms (Jodha 2000, 2005). The autonomy and flexibility of decentralized traditional institutions at the 
community/local level in the $\mathrm{HKH}$, as well as natural resource endowments, have helped communities adapt to changes in the past, and these attributes should therefore be preserved and strengthened into the future (Foggin 2018).

In the rural areas of $\mathrm{HKH}$ natural resources are an important component of sustenance for local communities, and the various institutional arrangements that have evolved over the years represent communities' ways of adapting to the vagaries of nature. However, over time the infrastructural and physical changes have been accompanied by socioeconomic changes, followed by political as well as administrative changes, with a clear impact not only on how natural resources are managed, but also on how local communities look at and treat them. The shift from decentralized ownership, as well as access to centralization, has made this region vulnerable to large demands on goods and services made available by mountain ecosystems (Jodha 2005).

A majority of the inhabited areas in the HKH are facing challenges of sustainable development. This situation has been caused partly by the precarious state of environmental governance, wherein for many reasons regional governance systems are largely unable to address environmental issues. These include fragmented governance, where informal and formal governing institutions are not synchronized; lack of involvement from financial institutions in considering a "bigger picture" before they support external investments; and the proliferation of environmental agreements, often in conflict with trade agreements or practices. All these issues hinder proper functioning of regional governance. For example, high demand for mountain niche products can result in over-exploitation and thereby lead to degradation. With no policy in place and no institutional mechanism to implement, monetary incentives result in the breakdown of local institutions. Similarly, although most areas in the $\mathrm{HKH}$ are experiencing the phenomenon of depopulation due to migration, the population of the plains is growing continuously (along with aspirations), which itself has also had growing direct implications for the exploitation of natural resources in the mountains.

Lack of integration of sector policies, which is common to all HKH member countries, has been exacerbated by inadequate institutional capacities in mountain regions, including local governments and local communities (Agrawal et al. 2016; Foggin 2008; ICIMOD 2012). The absence of a gender perspective, and of values of equity and participation in governance, has led to an inability to persuade and influence the public and win the support of public opinion (UNEP 2002, 2008). Generally, environmental problems are embedded in very complex systems, of which our understanding remains quite weak (Underdal 2010). Because of the time lag between human action and environmental effect (hysteresis), the shift from awareness to action sometimes can take as long as a generation. Thus, governance- especially regional governance-has been overlooked by most member countries, although verbal assent can often be heard (Agrawal et al. 2016).

\subsubsection{External Knowledge and Technological Innovations}

In addition to local tacit knowledge about the environment and its management, which has developed over millennia, the accessibility to and penetration of modern science and technology are amongst the key driving forces behind the three pillars of mountain sustainability. Both the generation and dissemination of traditional and scientific knowledge and associated technologies have significant implications for both conservation and development. Technological implementation can have both positive and negative effects on the environment and human wellbeing (Nelson et al. 2006). This can be seen, for example, in increasing food production, improved accessibility of mountain communities to the external world, and also changes in human consumption patterns. Generally, in the remote mountains of the $\mathrm{HKH}$, inadequate access to appropriate technologies and scientific knowledge is one of the causes (through their absence) of poverty and natural resource degradation (Maikhuri et al. 2011), along with weak systems for communication and dissemination of knowledge. In the following sections, a few innovative areas of technology with major influence on mountain societies are highlighted.

\subsubsection{Information and Communications Technology (ICT)}

ICT is instrumental in reshaping and transforming numerous aspects of the world's economies, governments, and societies, and is becoming one of the fastest-growing industries in the global economy in the 21st century (Baller et al. 2016). Increased availability of information and knowledge-sharing platforms is key to fostering socioeconomic development and also increases awareness about environmental issues, related government legislations, and subsidies (Thapa and Sein 2010; QBE Asia Pacific 2017).

The mountain communities in the HKH suffer from lack of access to basic resources, services, and relevant information (Akhtar and Gregson 2001). However, various agencies working in the region, including governments, non-governmental organizations (NGOs), and public and private entities have shown a growing interest in promoting and using information and technologies to improve people's quality of life and their livelihoods, to link the HKH with markets outside the region, and to reduce the marginalization of mountain communities (Thapa and Sein 2010).

Within the $\mathrm{HKH}$, there are significant differences in terms of the number of mobile subscribers who have used mobile 
internet services. Highly advanced markets such as China already show above $40 \%$ of the population using mobile internet services, followed by India (22\%). However, less than $20 \%$ of the populations of Myanmar, Bangladesh, Pakistan, Nepal, and Bhutan have used mobile internet services. This naturally leads to a great potential for the emerging markets within the region, in terms of mobile internet subscribers, when identifying growth opportunities (GSMA Intelligence 2015).

Increased availability of information and knowledge-sharing platforms are key to fostering socioeconomic development (Thapa and Sein 2010) as well as enhancing environmental governance, associated with governmental legislation and the development of cleaner technology (IUCN 2017). There is increasing evidence that ICT tools such as radios, internet, TV, and e-magazines are being used for communicating and information sharing (Adhikari et al. 2006). ICT tools also are being used to simplify technical information and to share more accurate and up-to-date information with different communities (Baral et al. 2006). Use of ICT for agro-advisory services and early warnings in disaster situations has also emerged as an effective adaptation measure to deal with the impacts of climate change, weather irregularity, and geo- or biodisaster planning (Baller et al. 2016; QBE Asia Pacific 2017). Another important use for these technologies concerns mitigation of remoteness, whether social or geographic, particularly in relation to increasing people's accessibility to education, healthcare, and natural risk warnings and rescue.

\subsubsection{Geospatial Technology and Improved Regional Perspectives}

Geospatial technology also is recognized as an effective tool for planning, management, and decision making locally, regionally, and globally. The rapid development of geospatial applications has allowed it to be used widely for mapping LULCC; to predict agricultural productivity and natural disasters such as landslides, avalanches, and glacier change (Manfré et al. 2012); and to plan transportation networks and environmental protection (Ingole et al. 2015).

A large temporal and spatial variability in ecological and socioeconomic aspects exists across the HKH with respect to geographical, physical, socioeconomic, and cultural parameters. To understand such large variability in the region and to successfully use that information to predict changes and apply effective natural resource management practices, it becomes essential to use technology that allows access to data over large scales and which provides a platform for integrating geographic data with sociocultural and economic factors.

In the last two decades, ICIMOD and its regional and international partners have successfully applied geospatial and allied technologies for understanding glacier dynamics in the context of climate change, forest fire monitoring with
SMS alerts, land cover change assessment for natural resources, deforestation and forest degradation monitoring, vegetation shift and corridor identification in transboundary landscapes, disaster information management and flood early warning systems, and agriculture monitoring for food security analysis (Bajracharya et al. 2007; Li et al. 2017; Qamer et al. 2016; Uddin et al. 2016). GIS platforms and analytic tools also are being used to monitor changes in natural ecosystems (Chaudhary et al. 2014; Gilani et al. 2017).

\subsubsection{Biotechnological Applications in Agricultural Production Systems}

Biotechnology has evolved rapidly to address the existing problems of food, health, and environmental security (Padmanaban 2003) and conserving biodiversity (Joshi et al. 2009). It is being used in medicinal and aromatic plants (Adhikari 2011; Joshi et al. 2009; Juyal et al. 2014), forestry, and agriculture with the development of pest-resistant or drought-resistant seeds, high-yield varieties, biofertilizers, biopesticides, and biofuels. There is no common opinion on this topic, neither between countries nor at the regional level; and not even amongst all the authors of this chapter. The topic is highly contested (see, e.g. for Burkina Faso, Le Monde 2015). In Switzerland, for example, environmental organisations and small scale farmers (who are located especially in mountains) have enforced a moratorium of genetically modified (GM) organisms until 2021. Conversely, several HKH countries see plant and animal GM organisms as powerful tools that hold the promise of improving the productivity, profitability, and sustainability of farm systems, including those in poor districts (Adhikari et al. 2006; Cohen 2005; Delmer 2005).

Biotechnology has potential benefits as well as risks when applied to agricultural crops. Its proponents say that the introduction of genetically modified crops has reduced the spread of diseases, yet there remain concerns regarding the reduction of native crop genetic diversity due to GM plant breeding programmes (Li et al. 2016; Rauf et al. 2010). GM approaches also have generated questions about their possible negative consequences on health, society, and the environment (Akumo et al. 2013; Fisher et al. 2015; Shahzadi et al. 2015). Negative health implications for farmers due to increased exposure to toxins, and to allergic reactions, have also been reported in some studies (Debyani and Neeta 2012; Prakash et al. 2011). Critics also argue that the interactions of GM organisms (GMOs) with existing biodiversity are not yet clarified and therefore unsafe, or at least ill-advised according the precautionary principle. Additionally, GMOs are sterile and farmers therefore must continuously buy seeds from the copyright holding companies, rendering them both financially and technologically dependant. External knowledge also begins to replace regional mountain knowledge (Forster et al. 2013; Public Eye 2017). Furthermore, dependency on 
external private enterprises endangers the sovereignty of national states in issues of food (De Schutter 2010; UNCTAD 2009). It will be important to look at the biosafety aspects of using new varieties, which may interact with the environment to produce sterile seeds and affect local terrestrial and aquatic populations. A balanced view also demands that even with the new CRISPR (Clustered Regularly Interspaced Short Palindromic Repeats) technologies, coexistence with organic farming must not be inhibited - that is, the option to return to earlier non-GM ways in the future must always be kept open (Niggli 2016).

Extension of agricultural land use coupled with replacement of traditional staple food crops by cash crops, modern and high-yielding varieties, and improved cultivars within existing cropping systems (Agnihotri and Palni 2007; Bardsley and Thomas 2005; Rana et al. 2009; Saxena et al. 2005) is driving the loss of genetic diversity (Xu and Grumbine 2014) and associated traditional farming knowledge. The replacement rate of local seed (landraces) has increased with distribution of modern seed varieties (Rana et al. 2009). In the Humla district of Nepal, rice subsidies over the past 30 years have increased dependence on this staple crop, resulting in the decline in cultivation of indigenous cereal crops such as barley foxtail, panicum and finger millets, buckwheat, amaranth, and beans (Roy et al. 2009).

In the western Himalaya a shift in land use (from subsistence farming to commercial farming), particularly the cultivation of vegetables and fruits as cash crops and the continued use of high-yield crop varieties, has become the principal reason for erosion of genetic diversity (Agnihotri and Palni 2007; Rana et al. 2007; Sharma and Chauhan 2013) and degradation of natural resources (Saxena et al. 2005). Although cash crops have brought substantial economic benefits to local farmers (Saxena et al. 2005), the shift from highly diverse systems to monoculture agriculture also has promoted the excessive and often indiscriminate use of chemicals and pesticides (Kala 2014). Furthermore, the loss of biodiversity could compromise the potential to obtain improved varieties which could help people adapt to changing conditions in the future.

\subsection{Economic Drivers of Change to Mountain Sustainability}

\subsubsection{Economic Growth and Differentiation}

Rapid economic developments have occurred in most HKH countries, creating national and local economic opportunities. Increased trade, tourism, resource extraction, and labour migration have opened avenues for income generation and local development; yet large challenges come with these changes (Box 2.5).

\section{Box 2.5 Challenges of economic development in the HKH}

Poverty in the HKH is still widespread (Gerlitz et al. 2012) and inequalities between highland and lowland -due to unequal access to markets, inadequate infrastructure, and failed or insufficient policies that do not sufficiently incorporate mountain specificities - are increasing.

Indigenous people and ethnic or religious minorities - a significant part of the population of the HKH - generally benefit less from economic development than the larger population group in urban centres. Instead, indigenous people are often the most underprivileged and vulnerable groups in the mountains (Gerlitz et al. 2012; Lama et al. 2010).

Despite efforts to promote regional economic integration and transboundary exchange, the $\mathrm{HKH}$ remains one of the least integrated regions in the world. The borderlands, while creating opportunities for some, continue to constitute significant barriers for exchange. Subsistence and non-monetized economies still play an important role, especially for pastoralists in the high altitudes around these national borders.

Mountainous areas are also often zones of instability and conflict (such as in Kashmir or north Myanmar) (Starr 2006) with significant shadow or conflict economies (for example, human trafficking and illicit trade in timber, precious stones, and drugs).

Informal economic activities, especially in rural parts of the HKH, play a considerable role in local livelihoods but their relative contributions are hard to estimate.

The countries of the HKH have made remarkable economic achievements in the last decades. Since the initiation of market reforms in 1978 and the shift to a market economy, China has experienced rapid economic development with an average annual gross domestic product (GDP) growth of nearly $10 \%$, a rise in GDP from USD 148.4 billion in 1978 to USD 10.9 trillion in 2015 , and a rise in GDP per capita from USD 980 in 1990 to USD 14,200 in 2015 (World Bank 2016). Between 1990 and 2005 alone, China lifted 470 million people out of extreme poverty (Wang et al. 2015). South Asia, mainly driven by the economic development of its largest economy, India, has also experienced robust economic growth; and, with a regional average GDP growth of $7.1 \%$ in 2016, is now the fastest-growing developing region worldwide. ${ }^{2}$

\footnotetext{
${ }^{2}$ See: http://www.worldbank.org/en/news/press-release/2016/04/09/ south-asia-fastest-growing-region-world-vigilant-fading-tailwinds.
} 
Despite these impressive national growth figures, economic development in the region varies both among and within countries. China's mountainous HKH provinces (Xizang/Tibet Autonomous Region (TAR) and Yunnan, Gansu, Qinghai and Sichuan provinces) lag far behind the coastal provinces both in terms of per capita GDP and rate of poverty reduction (Fang and Ying 2016). In India there is no consistent trend, with per capita income in some mountain states above the national average (e.g., Himachal Pradesh) and others severely below (e.g., Manipur, Assam, Jammu, and Kashmir).

Social instability and prolonged conflicts have notably hampered the performance of some countries (Afghanistan, Pakistan, and Myanmar), and states that are largely mountainous (Nepal and Bhutan) are also lagging behind. Mountain people in the HKH remain economically vulnerable; sustainable development efforts have not produced the desired outcomes; and mountain poverty in the HKH is still widespread (Gerlitz et al. 2015).

The vast majority of mountain people in the HKH are dependent on agriculture and animal husbandry; but growing population numbers have put additional stress on already limited mountain resources and have increased the workforce to the extent that it cannot be absorbed by traditional farming systems. In Nepal, for example, nearly three-quarters of the labour force is dependent on agriculture, which contributes to only $37.4 \%$ of GDP (Nepal and Henning 2013), while employment opportunities outside the farm sector are stagnating and the economy is characterized by a low salary structure (Shrestha 2008). In this respect, one livelihood strategy for mountain people is migration to national urban centres, more industrialized Asian countries, and the Gulf States. The remittances migrants send home are significant sources of income for households in mountain areas throughout South Asia. In Nepal, they amount to more than one-third of national GDP and are a major factor contributing to a balance of payment crisis (Shrestha 2008). Additionally, much of the potential labour force is then missing to sustain the traditional agricultural systems, which are degraded by underuse.

In addition to remittances, other external financial contributions are essential for the HKH. For example, in India, several hill states receive special subsidies through the Hill Area Development Programme and other schemes, while the economies of China's mountainous provinces such as Xizang/TAR rely heavily on subsidies and assistance from Beijing (Jin 2015). Official international development cooperation is also an important source of revenue for some HKH countries such as Afghanistan, Bhutan, Bangladesh, and Nepal, with foreign development grants accounting for significant shares of the annual national budget. While large contributions come from outside the region, regional cooperation also is growing. India and China are the largest contributors; in 2015-16 India allocated more than $80 \%$ of its USD 1.6 billion foreign aid budget to South Asia, with $63 \%$ going to Bhutan alone (Piccio 2015).

Hydropower development (e.g. in Bhutan) and resource extraction generate significant national or local revenues, but they can also lead to environmental degradation (e.g., timber extraction in Pakistan; Ali and Benjaminsen 2004), the withdrawal of the economic basis of pastoralists (see, e.g., Rousselot 2015 for Lesotho in Africa), and local conflicts (Agnew 2011; Global Witness 2015).

Leisure and religious tourism also contribute to the economic development of the HKH and have become significant drivers of socioeconomic and environmental change. Since Bhutan introduced tourism in 1974-with the primary objective of generating foreign exchange revenues (Dorji 2001) - the number of tourists has climbed sharply from 287 to over 7000 in 1999 and more than 155,000 in 2015; tourism now generates annual revenues of over USD 70 million (Tourism Council of Bhutan 2015). In Nepal, with its spectacular mountain scenery and its rich Hindu and Buddhist heritage, tourism has become one of the country's strongest industries. It generates employment opportunities as well as foreign exchange earnings and GDP growth, while also having positive effects on the demand for goods and services, transportation, and communication infrastructure (Gautam 2011; Paudyal 2012). Tourism is an important contributor to the state economy of Himachal Pradesh, India, and to Xizang/TAR, China, where tourist numbers-facilitated by improved rail and air transport to Lhasa in recent years-reached 9.25 million in 2014 and generated revenues of CNY 11.2 billion yuan (USD 1.79 billion) (Xinhua 2015). Herein, we can also clearly see huge risk for potential over-exploitation. Tourism related to summit expeditions (e.g., Mount Everest), alpine trekking, and visiting notable landscape features has become a global export product, but also can create localized conflicts with local populations because of use conflicts (Naitthani and Kanthola 2015; Rao et al. 2000) or problems of over-exploitation (with violent attacks between expedition members at Mount Everest in April 2013). Second homes owned by rich multilocal people from Mumbai, Delhi, and the Gulf States also are sprawling into the unstable hills around Nainital/Uttarakhand, India (Tiwari and Joshi 2016).

Regional and transboundary trade are important for both mountain countries and mountain people along the borders. For example, driven by Chinese demand, Yarsagumba or caterpillar fungus (Cordyceps sinensis) has become one of the most important sources of cash incomes for mountain people in large parts of the Tibetan Plateau and the India, Nepal, and Bhutan Himalaya (Winkler 2009). Complicated border procedures, insufficient border infrastructure, and a complex socio-political environment, however, mean that regional trade performs well below its potential, and South 
Asia remains one of the most un-integrated regions in the world (Ahmed and Ghani 2015).

The South Asian Association for Regional Cooperation (SAARC) and the South Asia Subregional Economic Cooperation (SASEC) Program, aimed at improving regional economic opportunities and fostering connectivity with China and Southeast Asia through Myanmar, still have a long way to go before the mountain people of the HKH can genuinely benefit. Other large regional and international initiatives also attempt to increase regional connectivity and economic integration:

- India's 'Look East' policy has gained new momentum with the opening of Myanmar since 2012;

- Pakistan and China are creating an economic corridor with considerable investments in infrastructure and energy generation in Pakistan's mountainous provinces;

- China announced a modern version of the ancient Silk Road with its 'One Belt, One Road' initiative that aims to connect large parts of Asia with Europe and East Africa through maritime (belt) and overland (road) connections; and

- Bangladesh, China, India, and Myanmar are establishing an economic corridor that will eventually connect Kunming in China's Yunnan Province with Kolkata (India) via Mandalay (Myanmar) and Dhaka (Bangladesh).

It is too early to estimate the full impact of these large initiatives, but they are likely to shape socioeconomic dynamics in the HKH for decades to come. In light of this increasingly rapid globalization and because of the constraining mountain specificities of fragility, marginality, and inaccessibility, further economic integration requires strong and mountain-specific policies to avoid increased dependencies and inequities in highland-lowland exchanges (Jodha 2000, 2005).

As in similar cases in history and in other parts of the world, these economic development processes go hand in hand with a differentiation and polarization in society whereby more active and dynamic families can profit from open and enlarged markets and new demands, while lower-performing individuals or households become increasingly dependent on low-wage jobs or are forced to out-migrate, at least temporarily (e.g., Sherpa society in the Khumbu area) (Jacquemet 2017). We see similar processes in other mountain resort towns, such as several waves of resort development in the European Alps in the late 19th century and from the 1960s to the present, and in the Rocky Mountains in Canada and USA since the 1980s (Glorioso and Moss 2006).

\subsubsection{Rapid Infrastructure Development}

In 1994, the World Development Report argued that good infrastructure can raise the overall economic performance of a country, contribute to poverty reduction, and help to improve environmental conditions when the provision of service infrastructure responds efficiently to demand (World Bank 1994). Further studies have demonstrated the positive correlation between infrastructure, income levels, and (rural) development (Calderón and Servén 2004; Cook 2005).

In recent decades, increased access to and within mountainous areas in the HKH because of the creation of hard infrastructure has indeed been a powerful driver of change. The expansion of roads and road networks has played the most important role and helped to reshape socioeconomic and political relations within mountain areas, and also between mountains and the downstream centres of population. While it is generally assumed that access (especially through roads) represents opportunities for development, it also can contribute to increases in resource extraction from mountainous areas, growing dependencies on markets in the lowlands, pollution and environmental degradation, out-migration, and (potentially) sociocultural conflict. Also, as the level of infrastructure development varies, the impacts derived and pace of development are distributed unequally between and within regions (Kohler et al. 2001; Kreutzmann 2004).

Comprehensive data on infrastructure in the $\mathrm{HKH}$ are still not available. While the South Asian region faces an infrastructure gap of USD 1.7-2.5 trillion until 2020 (Biller et al. 2014), no consistent estimates are available that demonstrate how much of this amount needs to be invested in mountain infrastructure. Also, access to infrastructure within and among South Asian countries is extremely variable, but in general accessibility is lower in countries with large areas of mountainous geography, low rates of development, and long internal conflicts, such as Afghanistan and Nepal (Biller et al. 2014).

Difficult geography, high construction costs, the proximity to sensitive national borders, and a lack of economic incentives for central planners mean that physical infrastructure in the mountains has long been underdeveloped. Early road expansion in the eastern and western Himalaya was guided more by strategic and military interests than by an aim of providing better transport facilities for mountain people. Since the 1990s, however, many of these roads have become accessible to civilians, and the network of roads accessible to motor vehicles has expanded, providing access to hitherto remote and inaccessible mountain valleys, such as Pakistan's Gilgit-Baltistan or north-eastern India (Das 2008; Kreutzmann 2004). 
While Nepal had only $2700 \mathrm{~km}$ of road in the early 1970s, the official road inventory in 2011 listed approximately $11,000 \mathrm{~km}$ of strategic roads and $60,000 \mathrm{~km}$ of rural roads. However, only half of the strategic road network and $5 \%$ of the rural network are paved (World Bank 2014). Bhutan, which began road development in the early 1960s, now has a road network of $10,578 \mathrm{~km}$ built mainly with outside support and comprising $2436 \mathrm{~km}$ of national highways and expressways; $1190 \mathrm{~km}$ of district roads; $5257 \mathrm{~km}$ of rural farm roads; $350 \mathrm{~km}$ of urban roads; $667 \mathrm{~km}$ of forest roads; and $678 \mathrm{~km}$ of other access roads (Asian Development Bank and Royal Government of Bhutan 2014).

The high investment costs in engineering and materials and the geographical conditions in the HKH, with its high mountain passes and frequent river crossings, have hindered road development. In addition, heavy monsoon rainfalls in parts of the $\mathrm{HKH}$, human impact through deforestation or building construction (Haigh and Rawat 2011), and weakened slope stability due to increased road development itself (as in China's western Yunnan Province; Sidle et al. 2014), cause numerous landslides along mountain roads (see Sect. 2.2.5, Mountain hazards). The resulting high cost for road maintenance means that many mountain roads are in poor condition. The summer rainy season and heavy winter snowfalls also make many roads impassable for much of the year. Access and connectivity in the HKH therefore cannot depend only on paved and unpaved mountain roads; it also depends on a network of trails, suspension bridges, and ropeways. Porters and animal transport by donkeys, yaks, and yak crossbreeds also still play an important role in higher elevations and remote areas (Starkey 2001; Wu et al. 2016b). Additionally, air transport is indispensable-especially in remote and otherwise inaccessible areas-often with small airports and untarmacked runways.

The only country in the HKH with established major railways to and in the mountains is China. A spectacular railway with large parts of the tracks on permafrost on the Tibetan Plateau connects Golmud (Qinghai) with Lhasa (Xizang/Tibet) was opened in 2005 and was recently expanded to Xigazê (Shigatse) in 2014.

The potential for hydropower in the HKH exceeds 500 GW (Vaidya 2012). Harnessed properly, this energy could trigger a socioeconomic transformation and have a tremendous impact on the lives of mountain people. However, despite the high potential for hydropower, the energy economy in the region is still weak and characterized by limited access to clean and modern energy services, low per capita consumption, a relatively high consumption of non-commercial biomass, and a high and growing dependency on imported fossil fuels (Asian Development Bank 2013; Shrestha 2013). Energy poverty is high (Rasul and Sharma 2015) and electricity (apart from in China) is available to only half of the population in the HKH (Vaidya
2012). A strategy for strong tourist development increases the needs for energy and may serve as a driver the extension of hydropower installations in Nepal and India (Fort 2017; Naitthani and Kanthola 2015).

In the future, energy poverty could be minimized and a strong driver for change in the mountains could be promoted by:

- Modern technologies that increase the efficiency of fuelwood (still the most important source of energy for many mountain people, both for cooking and heating) and decrease related carbon emissions;

- Decentralized small-scale hydropower development; and

- Better local, national, and regional grid connectivity that could also facilitate hydropower export (but this should be used carefully, and mainly as a means of supra-national cooperation under the aspect of supply security $^{3}$; if it is developed under a merely commercial logic, it risks severe environmental damage and social challenges). The further extension of new sources of energy such as active and passive solar energy also is very important.

\subsubsection{Urban and Peri-urban Expansion}

Urbanization in the $\mathrm{HKH}$ is an independent driver with cross-cutting impacts on the three pillars of mountain sustainability. Urbanization is understood here in a sociological sense, which includes demography, migration, and the differentiation to market economies; it considers especially the socioeconomic processes at play in a given territory (Brenner and Schmid 2014). More succinctly, urbanization encompasses the overall processes of association of people, and concomitantly the movement from generalist towards specialisation - with societies in urban or peri-urban settings largely dependent on broad division of labour and exchange of services.

Urbanization should not be confounded with urban expansion, urban sprawl, or the creation of cities and agglomerations - phenomena which are only part of the comprehensive social process of urbanization. This umbrella term is more comprehensive and includes aspects which are not directly visible, such as temporary outmigration (multilocality), second homes for leisure, or internet-based

\footnotetext{
${ }^{3}$ In Bhutan, hydropower export to India is already a major source of revenue. Nepal, on the other hand, is currently a net importer of electricity from India despite an abundance of hydropower resources (Asian Development Bank 2013). For longer discussion on the problem of the impacts of the use of hydropower on local populations, see Rousselot (2015) and Agnew (2011).
} 
activities in areas which at first sight look purely "rural". In this section it is not possible to consider all aspects of urbanization, and we focus mainly on processes related to an ongoing concentration of jobs and people in local centres, cities, or urban agglomerations which often show a spatial sprawl, concomitantly with a relative depopulation in regional peripheries. Over the last three to four decades, human settlements in the HKH have grown both in numbers and in size, with small villages transforming into larger towns and former towns into major metropolitan areas (Ghosh 2007; Pandit 2009).

Urbanization is, on one hand, the consequence of both global and regional socioeconomic driving forces. A global division of labour, production, and trade increases the shift of labour from manual work to more complex organization, logistics, and commercial services, as can be observed in societies of developed countries in North America and Europe (Fourastie 1989 [1949]). There is a widespread, global tendency towards the concentration of populations in dense agglomerations (UNFPA 2007). However, the trajectory of urbanization in the $\mathrm{HKH}$ is unique: unlike in the European Alps, for example, the $\mathrm{HKH}$ is not comprised of a single or uniform economic space, as multiple national borders and the regional geopolitical constellation of States in HKH play an important role.

Temporary and permanent outmigration from the region with dependencies on foreign remittances is said to be the highest in the world, due largely to enormous disparities in wealth (Karki et al. 2012). In contrast, global outdoor tourism induces the growth of urban agglomerations, resorts towns, and urban infrastructure such as airports. Small and medium-sized local centres in the hills play a specific and particularly important role for the peripheries, as they are privileged places for the introduction of public infrastructure, health services, and technologies, and also for consumer goods. Tourism can thus introduce a market society and simultaneously weakens local agrarian society that has long been based at least partly on subsistence. Both the internal and external frameworks of HKH societies constitute the drivers for an urbanization that follows a combination of both global tendencies and HKH specificities.

On the other hand, urbanization is itself also a driver of change. Existing towns attract people by promising better livelihoods and income, more individual freedom, and larger social networks. The functional division of labour allows cities to create economies of scale (agglomeration economies) which enables cities to concentrate more economic wealth. Agglomeration economies allow them to create jobs, attract reinvestments and remittances, and encourage people to migrate from the rural hinterlands in search for a better life. In cities, space is scarce, and this results in higher buildings made of concrete instead of the locally manufactured brick. Cities change the nutrition regime of the local population who use refrigerated, imported food instead of supplies from local markets. However, the converse also is possible, and agglomeration diseconomies may occur such as increasing pollution, congestion, or insecurity. In such instances, the growth poles may then shift to other agglomerations (cf. Krugman 1991; Marshall 1890; Moriconi-Ebrard 1993; Pumain 1999; Richardson 1995; Storper 1995, among many others).

In order to evaluate and interpret urban development and urbanization it is important that analysis is not restricted to just the high altitudes. Quantitative and qualitative analysis and mapping of the HKH requires the large agglomerations in the foothills to be included, as these lowland areas are primary drivers for regional and international exchange, guarantee accessibility to the mountains, and also attract people from the mountains. These mountain-lowland linkages have become crucial in the mountain ranges of the developed countries with mountain ranges such as the Alps (Perlik 2018); they are even more important in mountain regions where national borders play such critical roles as in HKH. One very significant observation from the European Alps is that the lowland-mountain relationship has continuously to be renegotiated. In particular this relationship defines the demands of the urban population in the lowlands for specific mountain resources, and the need of the mountain population to be protected against natural hazards as well as territorial insecurity. These mutual dependencies and benefits need to be balanced fairly.

In the HKH we see similar spatial processes as in the mountains of the developed countries of the Global North. Similar phenomena affect the environment and society, such as the decline of agricultural subsistence economies as a consequence of the rapid increase in tourism (Jacquemet 2017) or second home residences (Tiwari and Joshi 2016). The latter generally are premised on, or require, integration of mountains in the national and international economy, increased division of labour, and investments in construction and infrastructure. Dynamic urban development also is often observed along international transport routes (for instance along the Karakoram Highway) (Karrar 2013).

There are, however, two important specificities in the HKH. The first is the different development trajectory that has occurred due to the historic path of colonization, post-colonial constellations, and Cold War geo-strategies in the Himalaya. The emergence of the states of China, India, and Pakistan gave rise to the territorialized border regions and the development of a decentralized infrastructure, as well as new trade relations. Today, the Himalaya has a new position as a large hinterland in relation to the hotspots of globalization with their fast-growing economies. The second difference is the time lag with which urbanization is introduced or occurs (hysteresis) in the region. As urbanization takes place in a period of global exchange, where the main 
manufacturing sites of the world have become centralized outside the mountains, the modern development of mountain areas is narrowed on leisure, tourism, raw materials, and water (Perlik 2018). In some places this delay may to a certain degree prevent some forms or the extent of toxic pollution in mountains, but it also can enlarge the impacts from global tourism, hydropower dams, and abandoned agriculture. Such hysteresis also means that decision centres even for mountain urban agglomerations are almost entirely located in the lowlands, where mountains are often seen as inferior or backward and thus mountain challenges are aggravated.

While urbanization and urban development in the $\mathrm{HKH}$ can be explained largely on the basis of similar mechanisms and drivers as seen globally, in the framework of global change and also considering the consequences of the regional $\mathrm{HKH}$ trajectory along with certain standard urban patterns (e.g. nation building with a national capital, the effects of global tourism, abandonment and concentration of local markets), certain other processes are specific to the HKH. These include, for example, early forms of territorialization with garrisoned armed forces, creation of centres of international logistics, and the presence and actions of global development and environmental NGOs. Five functional urban patterns can be observed in the HKH.

\subsubsection{National and Regional Capitals}

National and some regional capitals follow their own interests and often compete for status as global cities. They also are perceived as high-end "Central Places" which hold the highest functions and services, in the interest and for the prestige of the whole country. They define national standards of economic activities and the range of consumer goods available. They also are the only diversified places in the frame of urbanization, and they attract all kind of workforces (from unskilled workers to highly qualified specialists) from other parts of the country as well as expat populations. As such, national resources are disproportionally concentrated in these places. As mountain regions rarely hold such capital functions, at least on a global scale, they are often at a relative disadvantage. In the $\mathrm{HKH}$, however, the majority of national capitals lie within the mountain perimeter. Only China, India, and Bangladesh have their national capital outside the mountain ranges, yet China still invests disproportionally in Lhasa and TAR, and India has given Uttarakhand the status of a federal state. In Nepal the mountain part of the country, including Kathmandu, is clearly also considered more important than the lower-lying plains.

\subsubsection{New Hotspots of Territorialization}

Even small and medium-sized towns may be involved in a dynamic growth process whereby - whether by chance or due to the development of new infrastructure - they become connected to national and international decision making. This can be the case when they suddenly find themselves in the centre of a regional conflict, or as they become centres for logistics, administration, or a new border crossing. With the opening of the Karakoram Highway in Pakistan in 1978, for example, a number of adjacent settlements rapidly gained significance. The population of the city of Gilgit grew from 18,000 in 1972 to 57,000 in 1998 , and together with its rural hinterlands it has seen a population growth from 145,000 in 1998 to an estimated 222,000 in 2013 (Kreutzmann 1991; UN-HABITAT 2010). Such numbers are a clear indicator of a large in-migration that has taken place because of new infrastructure, and in some instances also due to insecurity and/or resource degradation elsewhere in the country. A similar development takes place in cities and settlements which have become focal points of military deployment or hubs for logistics and foreign aid. Kunduz, in the foothills of the Hindu Kush, had about 74,000 inhabitants in the 1960s, but this grew to 268,893 in 2012 (GoIRA 2015). The city now hosts troops and services related to troops, ranging from independent translators to large companies, and it also is a place for shelter-seeking refugees and NGOs caring for them. Development strategies to reinforce global tourism also result in the enlargement or new construction of international airports (e.g., at Pokhara) (Fort and Adhikari 2018; Rimal et al. 2015).

\subsubsection{Old Urbanization with Own Production Systems}

Shimla in Himachal Pradesh was chosen as the capital of British India during the colonial era because of its milder climate. Following independence Shimla lost this privileged status in favour of New Delhi but remained a centre of wool production. Today it is an important tourist destination. At present Shimla remains an important city with large hinterlands, although with a significantly lower dynamic $(143,000$ inhabitants in 2001 and 172,000 in 2011) than many other mountain centres in the region. In the last years Shimla has become renowned for its touristic qualities for both domestic and international tourists. The city has remained the critical mass and a sufficient hinterland to be able for restructuration during the process of development in India. Such cities are an example for the long standing impact of defined centres of power, may be due to economic decision making or due to political will. They reflect the successful cases while other towns - today unknown - declined or became integrated in larger agglomerations.

\subsubsection{Resort Towns for Tourism and Second Homes}

With the increase in global tourism and the emergence of urban middle classes in HKH states, resort towns that valorise landscape vistas and amenities and the reputation of 
prestigious holidays have developed in mountains. They offer tourist services including accommodation, guides for trekking tours, and ropeway infrastructure, and they deliver ambiance and prestige. Some places serve as locations for second homes, as in Nainital, Uttarakhand, frequented by clients from Mumbai and New Delhi as well as from Arab countries (Tiwari and Joshi 2016). The other type of resort towns are small cities near the peaks of renowned mountains, used by trekking tourists and national park visitors. In Joshimath, for instance, the snow resort in nearby Auli hosted the South Asian Winter Games in 2011.

\subsubsection{Local Centres}

The principal towns of a district or subdistrict mainly serve a supply function. They are the places of territorialization at lowest level (for local administration and services) and provide opportunities for local market exchange. Most local centres lie in the Himalayan hills but their distribution is rather uneven (in India they are represented by more than 500 towns, mostly small and medium-sized). Because of their hilly topography, scope for their expansion is limited and the accessibility by roads is difficult (Khawas 2007). With improved accessibility to the plain in the future, the socio-economic structure of these small towns may change. Its inhabitants may search for better jobs in the plain and become out-commuters (and may move definitely) while peasant farmers might abandon their villages in higher altitudes and move to these small towns for the new jobs and better services offered. We must also recognize that temporary outmigration from the hilly zones to the lowlands is already common practice (Benz 2014; Dame 2015).

The recent urbanization processes not only introduce a new pattern of spatial use to the mountains; they also introduce the predominance of a market economy and powerful economic and social actors from outside. These socioeconomic and cultural transformations are the most important factors related to urbanization. The new spatial pattern of land use in the $\mathrm{HKH}$ also has led to adopting the current urbanization model based on a large-scale functional division of labour, with a polarization of metropolitan hubs as centres of decision making and surrounding mountains as spaces of leisure. This functional cleavage can be seen well in Uttarakhand, India, where the majority of the territory is state property. The state is following a business model to introduce a professionalized tourism sector, with the aim to attract wealthy foreign tourists to the scenic landscapes of the Nanda Devi region. The concept is based largely on a traditional protectionist National Parks model that generally sees farmers or pastoralists as adversaries to environmental goals, with the administration attempting to prevent traditional activities of local communities (Naitthani and Kainthola 2015). At the same time, India's growing needs as an emerging country have spurred a construction boom including river dams to increase the production of hydro energy, which also is needed for the tourism sector. A concentration of activities on developing and operating tourism resorts and 'keeping out' peasant farmers and pastoralists are both constituent parts of the urbanization process in many places in the $\mathrm{HKH}$, yet from the perspective of sustainable development they are both highly problematic. In this regard, the HKH follows global tendencies, as in Europe and the USA, only considerably delayed (Moss and Glorioso 2014; Perlik 2011). Rural mountain economies are squeezed out in favour of leisure and residences.

\subsection{Conclusions}

Changes driven by various forces in the $\mathrm{HKH}$ are creating constraints as well as new opportunities for sustainable development. We found that environmental and socioeconomic changes in the $\mathrm{HKH}$ are driven by a network of interactions among a range of factors or forces. Although some of the elements of these networks are global (e.g., climate change, IAS, globalization, advancement of science and technology) or regional (e.g., pollution, migration), the actual set of interactions that brings about change is more or less specific to each place and related to particular mountain ecosystems or trans-boundary landscapes. There is thus a great spatial diversity amongst drivers of change and their impacts. Considering the entire $\mathrm{HKH}$, rapid demographic change and weak governance systems associated with economic growth and climate change, followed by increasing LULCC, and over-exploitation of natural resources, have had the greatest overall impact on the sustainability of mountain areas (see Table 2.1). At the same time, most of the drivers discussed above are currently increasing in intensity and this trend will continue in the near future.

In the HKH many challenges for sustainability are related to increasing demands on natural resources, which lead to further environmental degradation, unregulated urbanization and infrastructural development, and loss of traditional culture. Both endogenous economic growth and global demands on tangible and intangible mountain products are leading to increased and selective consumption of mountain resources. The transformation from subsistence economies to market-driven economies leads to temporary or permanent emigration to emerging economies abroad which absorb the mainly male workforce while women are overburdened in mountain villages. Spatially this results in a degradation of the cultivated landscape. Extraction of natural resources and establishment of intensive agriculture and plantations are altering the extent and species composition of natural vegetation and reshaping the rural landscape. Growing remittance flows to family members at home, raising their purchasing power, and the general search for a better livelihood are 
Table 2.1 Level of influence of key drivers of change in the Hindu Kush Himalaya on three pillars of sustainability

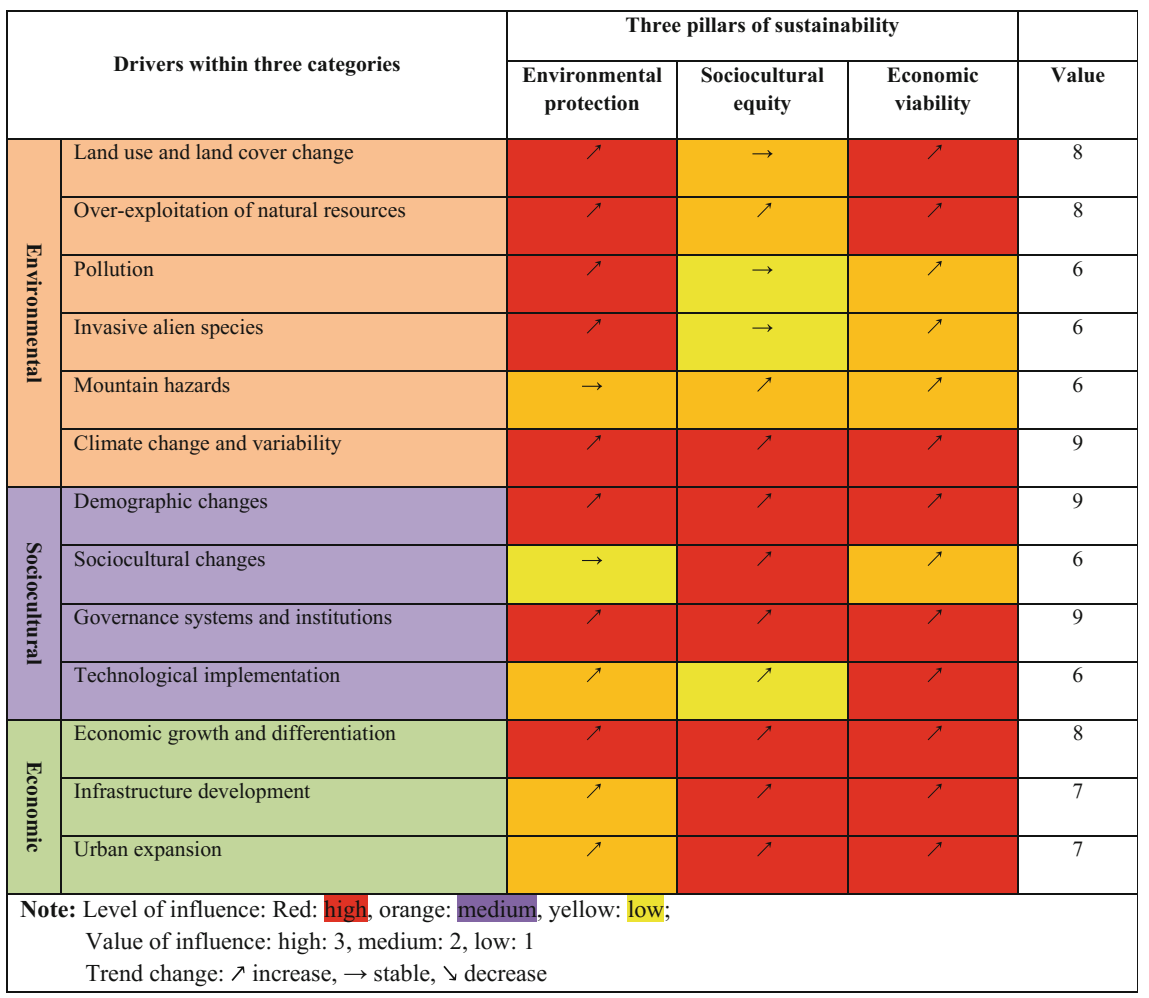

placing greater demands on local resources as well as imported goods. Increasing levels of international or interregional trade increase transport flows and introduce global products which generate huge external diseconomies (for instance, refrigeration, waste treatment, and sewage). At the same time they destroy traditional value chains of local agricultural products and crafts. Addressing these problems will require policy and action at local, national, and international levels, including common action among HKH states.

However, a range of opportunities also lies in the improving connectivity, including transportation and communication (which increase access to information), partnerships, and markets. Road network development is currently expanding accessibility, and international investment in agriculture and forestry in remote areas is driving new trends in rural economic activity. Enhanced access to health and education may be enabled and strengthened by economic growth and the advancement of science and technology. Additionally, a growing network of local urban centres may support the transmission of new prosperity to rural populations, as the development of mountain towns and cities may help-besides their mere economic power-to enhance the political influence of these regions within the national states.

While the drivers of change continue to demand individual identification and analysis, the complexity of their interactions also calls for a more comprehensive and integrated strategy to be adopted, such as promoting transboundary cooperation, and encouraging the development of mountain-specific responses by government policy makers. Horizontal analysis of policies and their anticipated impacts, whereby each sector is assessed in light not only of its own priority goals but also those of other sectors, is highly recommended (Foggin and Phillips 2013). Furthermore, advances in knowledge and rapid access to new technology are growing with the influence of globalization. As access to global services improves, the mountain specification of 'inaccessibility' will change to a certain extent. This will, in turn change the demand for specific ecosystem services, and enhance the capacities of local communities to adapt to global change. New financing mechanisms for climate change mitigation and infrastructure development equally offer valuable opportunities for increased investment in mountain regions. Thus, both proximate and ultimate drivers of change must be recognized and incorporated into more comprehensive concepts of development and approaches to development planning.

It has been recognized that an overall transition of mountain systems is taking place in the HKH. Growing global awareness about environment and society has signalled further modification in the stimulus for improved 
resource governance and institutional reform in the region. Sociocultural changes, infrastructure improvement, and technological implementation are also helping to pave the way for changes in mountain development, especially in remote high-altitude areas. People in the HKH are trying to mitigate the negative impacts of drivers or manage some drivers through more targeted, integrated, and collaborative actions. What is needed at present is a better understanding of changes and interactions, and of resulting trade-offs among different drivers, and enhanced regional interaction and coordination between upstream and downstream regions, populations, and decision-makers. Greater participation of local actors as well as high level transnational cooperation are both necessary to cope with current and potential conflicts and to collaboratively seek and develop viable opportunities for sociocultural, economic, and environmental improvements in the $\mathrm{HKH}$ in the future.

\section{References}

Adhikari, R. (2011). Biotechnology growth partnership: A potential flagship program in S\&T. Nepal Journal of Biotechnology, 1(1), $55-58$.

Adhikari, A., Upadhyay, M. P., Joshi, B. K., Rijal, D., Chaudhary, P., Paudel, et al. (2006). Multiple approach to community sensitization. In B. R. Sthapit, P. Shrestha, \& M. P. Upadhyay (Eds.), On-farm management of agricultural biodiversity in Nepal: Good practices. NARC/LI-BIRD/Bioversity International, Nepal.

Aggarwal, R. (2004). Beyond lines of control: Performance and politics on the disputed borders of Ladakh. India: Duke University Press.

Agnew, J. (2011). Waterpower: Politics and the geography of water provision. Annals of the Association of American Geographers, https://doi.org/10.1080/00045608.2011.560053. http://dx.doi.org/ 10.1080/00045608.2011.560053.

Agnihotri, R. K., \& Palni, L. M. S. (2007). On-farm conservation of Landraces of Rice (Oryza sativa L.) through cultivation in the Kumaun region of Indian Central Himalaya. Journal of Mountain Science, 4(4), 354-360.

Agrawal, N. K., Krishnan, A., Leikanger, I. C. P., Sherpa, J. D., Choudhury, D., \& Pantha, R. H. (2016). Action for mountain adaptation: Solutions beyond the boundaries of science, policy, and practice. Kathmandu: ICIMOD.

Ahmed, S., \& Ghani, E. (2015). South Asia's growth and regional integration-An overview. In S. Ahmed, \& E. Ghani (Eds.), SOUTH ASIA growth and regional integration (pp. 3-42). Washington, DC: The World Bank.

Akhtar, S., \& Gregson, J. (2001). Internet technologies in the Himalayas: Lessons learned during the 1990s. Journal of Information Science, 21(1), 9-17.

Akter, A., \& Zuberi, M. I. (2009). Invasive alien species in Northern Bangladesh: Identification, inventory and impacts. International Journal of Biodiversity and Conservation, 1, 129-134.

Akumo, N, Riedel, H., \& Semtanska, I. (2013). Social and economic issues-Genetically modified food. Agricultural and Biological Sciences, Food Industry. ISBN 978-953-51-0911-2.

Alam, R., Chowdhury, M. A. I., Hasan, G. M. J., Karanjit, B., \& Shrestha, L. R. (2008). Generation, storage, collection and transportation of municipal solid waste-A case study in the city of
Kathmandu, capital of Nepal. Waste Management, 28, 1088-1097. https://doi.org/10.1016/j.wasman.2006.12.024.

Ali, J., \& Benjaminsen, T. A. (2004). Fuelwood, timber and deforestation in the Himalayas. Mountain Research and Development, 24(4), 312-318.

Amin, A., Fazal, S., Mujtaba, A., \& Singh, S. K. (2014). Effects of land transformation on water quality of Dal Lake, Srinagar, India. Journal of the Indian Society of Remote Sensing, 42, 119-128.

Antonelli, A. (2015). Biodiversity: Multiple origins of mountain life. Nature, 524(7565), 300-301.

Ariza, C., Maselli, D., \& Kohler, T. (2013). Mountains: Our life, our future. In Progress and perspectives on sustainable mountain development from Rio 1992 to Rio 2012 and beyond. A global synthesis based on 10 regional reports. Geographica Bernensia.

Arya, D., Bhatt, D., Kumar, R., Tewari, L. M., Kishor, K., \& Joshi, G. C. (2013). Studies on natural resources, trade and conservation of kutki (picrorhiza kurroa royle ex benth. scrophulariaceae) from kumaun himalaya. Scientific Research \& Essays, 8(14), 575-580.

Aryal, S., Cockfield, G., \& Maraseni, T.N. (2015). Effect of summer livestock grazing on plant species richness and composition in the Himalayan rangelands. The Rangeland Journal, 37, 309-321. https://doi.org/10.1071/RJ14088.

Ashbolt, N. J. (2004). Microbial contamination of drinking water and disease outcomes in developing regions. Toxicology, 198, 229-238.

Asian Development Bank. (2013). Energy outlook for Asia and the Pacific 2013. Mandaluyong City, Metro Manila, Philippines: Asian Development Bank.

Asian Development Bank \& Royal Government of Bhutan. (2014). Three decades of development partnership: Royal Government of Bhutan and Asian Development Bank. Mandaluyong, Philippines: Asian Development Bank.

Atreya, K., Sitaula, B. K., Johnsen, F. H., \& Bajracharya, R. M. (2011). Continuing issues in the limitations of pesticide use in developing countries. Journal of Agricultural and Environmental Ethics, 24, 49-62.

Babel, M. S., Pandey, V. P., Rivas, A. A., \& Wahid, S. M. (2011). Indicator-based approach for assessing the vulnerability of freshwater resources in the Bagmati River Basin, Nepal. Environmental Management, 48, 1044-1059.

Bajracharya, B., Shrestha, A. B., \& Rajbhandari, L. (2007). Glacial lake outburst floods in the Sagarmatha region. Mountain Research and Development, 27(4), 336-344.

Bajracharya, S. R., Maharjan, S. B., \& Shrestha, F. (2011). Glaciers Shrinking in Nepal Himalaya.

Baller, S., Dutta, S., \& Lanvin, B. (Eds.). (2016). The global information technology report 2016-Innovating in the digital economy. Geneva: World Economic Forum.

Banerjee, S., Black, R., Kniveton, D., \& Kollmair, M. (2014). The changing Hindu Kush Himalayas: Environmental change and migration. The Netherlands: Springer.

Banjade, M. R., \& Paudel, N. S. (2008). Economic potential of non-timber forest products in Nepal: Myth or reality? Journal of Forest and Livelihood, 7, 36-48.

Banskota, M., Papola, T. S., \& Richter, J. (2000). Development in mountain areas of South Asia-Issues and options. Growth, poverty alleviation and sustainable resource management in the mountain areas of South Asia. In Proceedings of the International Conference Held from 31 January-4 February 2000 in Kathmandu, Nepal (pp. 1-31). Kathmandu, ICIMOD and ZEL.

Baral, K., Sapkota, T., Bhandari, B., Adhikari, A., Dewan, S., Pageni, P., et al. (2006). Rural radio programme: An effective tool for reaching the unreachable on biodiversity conservation issues. In B. R. Sthapit, P. Shrestha, \& M. P. Upadhyay (Eds.), On-farm management of agricultural Biodiversity in Nepal: Good practices. NARC/LI-BIRD/Bioversity International, Nepal. 
Bardsley, D., \& Thomas, I. (2005). In situ agrobiodiversity conservation: Examples from Nepal, Turkey and Switzerland in the first decade of the convention on biological diversity. Journal of Environmental Planning and Management, 49(5), 653-674.

Barua, S. P., Khan M. M. H., Reza, A. H. M. A. (2001). The status of alien invasive species in Bangladesh and their impact on the ecosystems. IUCN.

Bauer, K. M. (2004). High frontiers: Dolpo and the changing world of Himalayan pastoralists. Columbia University Press.

Bauer, K. (2005). Development and the enclosure movement in pastoral Tibet since the 1980s. Nomadic Peoples, 9(1-2), 53-81.

Baur, I. (2014). Analyzing and modeling the use of common property pastures in Grindelwald, Switzerland. Ph.D. Thesis. Munich: LMU. https://edoc.ub.uni-muenchen.de/18295/1/Baur_Ivo.pdf.

Benz, A. (2014). Multilocality as an asset. Translocal development and change among the Wakhi of Gojal. In H. Alff \& A. Benz (Eds.), Tracing connections: Explorations of spaces and places in Asian contexts (pp. 111-138). Berlin, Germany: Wissenschaftlicher Verlag Berlin.

Bergmann, C., Gerwin, M., Nüsser, M., \& Sax, W. S. (2008). Living in a high mountain border region: The case of the 'Bhotiyas' of the Indo-Chinese border region. Journal of Mountain Science, 5(3), 209-217.

Bhattarai, K. R., Måren, I. E., \& Subedi, S. C. (2014). Biodiversity and invasibility: Distribution patterns of invasive plant species in the Himalayas, Nepal. Journal of Mountain Science, 11, 688-696.

Bhusal, J., \& Subedi, B. (2014). Climate change induced water conflict in the Himalayas: A case study from Mustang, Nepal. Ecopersia, 2 (2), 585-595.

Biller, D., Andrés, L., \& Dappe, M. H. (2014). Infrastructure gap in South Asia: Inequality of access to infrastructure services. The World Bank.

Bing, H. J., Wu, Y. H., Zhou, J., \& Sun, H. Y. (2016). Biomonitoring trace metal contamination by seven sympatric alpine species in Eastern Tibetan Plateau. Chemosphere, 165, 388-398.

Bisht, N., Joshi, S., Shrestha, B. B., Yi, S., Chaudhary, R. P., Kotru, R., et al. (2016). Manual on invasive alien plant species in Kailash Sacred Landscape-Nepal. Kathmandu: ICIMOD.

Bolch, T., Buchroithner, M. F., Peters, J., Baessler, M., \& Bajracharya, S. (2008). Identification of glacier motion and potentially dangerous glacial lakes in the Mt. Everest region/Nepal using spaceborne imagery. Natural Hazards \& Earth System Sciences, 8, 1329-1340.

Bose, S., \& Jalal, A. (2004). Modern South Asia: History, culture, political economy (pp. 1-282). Taylor \& Francis e-Library.

Brenner, N., \& Schmid, C. (2014). The "urban age" in question. International Journal for Urban and Regional Research, 38(3), 731-755.

Bruinsma, J. (2003). World agriculture: Towards 2015/2030. An FAO perspective.

Budha, P. M. (2015). Current state of knowledge on invasive and Alien Fauna of Nepal. Journal of Institute of Science and Technology, 20, $68-81$.

Bull, A. T. (1996). Biotechnology for environmental quality: Closing the circles. Biodiversity and Conservation, 5, 1-25.

Burlakoti, C., \& Karmacharya, S. B. (2004). Quantitative analysis of macrophytes of Beeshazar Tal, Chitwan, Nepal. Himalayan Journal of Sciences, 2, 37-41.

Busby, J. R. (1988). Potential implications of climate change on Australia's flora and fauna. Greenhouse planning for climate change (pp. 387-398). Melbourne, Australia: CSIRO.

Byers, A. (2014). Contemporary human impacts on subalpine and alpine ecosystems of the Hinku Valley, Makalu Barun National Park and Buffer Zone, Nepal. Himalaya, 33, 25-42.

Cacopardo, A. M., \& Cacopardo, A. S. (2001). Gates of Peristan. History, religion and society in the Hindu Kush. Rome: IsIAO.
Cai, H., Yang, X., \& Xu, X. (2015). Human-induced grassland degradation/restoration in the central Tibetan Plateau: The effects of ecological protection and restoration projects. Ecological Engineering, 83, 112-119.

Calderón, C., \& Servén, L. (2004). The effects of infrastructure development on growth and income distribution. The World Bank.

Carpenter, S., \& Grünewald, F. (2016). Disaster preparedness in a complex urban system: The case of Kathmandu Valley, Nepal. Disasters, 40(3), 411-431. https://doi.org/10.1111/disa.12164.

Chakarvorty, M., Dwivedi, A. K., Shukla, A. D., Kumar, S., Niyogi, A., Usmani, M., et al. (2015). Geochemistry and magnetic measurements of suspended sediment in urban sewage water vis-a-vis quantification of heavy metal pollution in Ganga and Yamuna Rivers, India. Environmental Monitoring and Assessment, 187, 17.

Challinor, A. J., et al. (2009). Crops and climate change: Progress, trends, and challenges in simulating impacts and informing adaptation. Journal of Experimental Botany, 60(10), 2775-2789.

Chaudhary, S., Chettri, N., Uddin, K., Khatri, T. B., Dhakal, M., Bajracharya, B., et al. (2014). Implications of land cover change on ecosystem, ecosystem services and livelihoods of people: A case study from the Koshi Tappu Wildlife Reserve, Nepal. Journal of Institute of Forestry, Nepal, 14, 91-97.

Chavez, R. D., Taulicorpuz, V., Baldosoriano, E., \& Al., E. (2014). Climate change and indigenous peoples. Nordic Journal of Human Rights, 4, 235-237.

Chen, H., Liu, J., Xue, T., \& Wang, R. Q. (2012). Roads accelerate the invasion process of alien species. Advanced Materials Research, 347-353, 1483-1487.

Cheng, G., \& Tonghua W. (2007). Responses of permafrost to climate change and their environmental significance, Qinghai-Tibet Plateau. Journal of Geophysical Research, 112(F2), F02S03. http://doi. wiley.com/10.1029/2006JF000631. 17 Aug. 2016.

Cheng, S. (2007). Heavy metal pollution in China: Origin, pattern and control-A state-of-the-art report with special reference to literature published in Chinese journals. Environmental Science and Pollution Research, 14, 489-489.

Chettri, N., \& Sharma, E. (2016). Reconciling the mountain biodiversity conservation and human wellbeing: Drivers of biodiversity loss and new approaches in the Hindu-Kush Himalayas. Proceedings of the Indian National Science Academy, 82(1), 150-158.

China News Service. (2017). How to recover the Jiuzhai Velley National Park after earthquake remains controversial. http://news. china.com/news100/11038989/20170817/31114873_all.html.

Cohen, J. I. (2005). Poorer nations turn to publicly developed GM crops. Nature Biotechnology, 33, 27-33.

Collins, A. E. (2001). Health ecology, land degradation and development. Land Degradation and Development, 12(3), 237-250.

Cong, Z. Y., Kang, S. C., Zhang, Y. L., \& Li, X. D. (2010). Atmospheric wet deposition of trace elements to central Tibetan Plateau. Applied Geochemistry, 25, 1415-1421.

Cook, C. (2005). Joining the Mainstream: Impact of Transport Investment on Poverty Reduction-RETA 5947.' Presented at the ADBI Workshop on Transport Infrastructure and Poverty Reduction, ADB Manila, 18-22 July 2005.

Cordaux, R., Weiss, G., Saha, N., \& Stoneking, M. (2004). The northeast Indian passageway: A barrier or corridor for human migrations? Molecular Biology and Evolution, 21(8), 1525-1533.

Cui, X., \& Graf, H. F. (2009). Recent land cover changes on the Tibetan Plateau: A review. Climate Change, 94, 47-61.

Cui, P., Wei, F., Chen, X., et al. (2008). Geo-hazards in Wenchuan earthquake area and countermeasures for disaster reduction. Bulletin of the Chinese Academy of Sciences, 23(4), 317-323. 
Cui, P., Chen, R., Xiang, L., \& Su, F. (2014). Risk Analysis of mountain hazards in Tibetan Plateau under global warming. Advances in Climate Change Research, 10(2), 103-109.

Dame, J. (2015). Multilokalität im Himalaya: Diversifizierung der Lebenssicherung und neue Mobilität in Ladakh, Nordindien. In J. Poerting, \& M. Keck (Eds.), Aktuelle Forschungsbeiträge zu Südasien. Geographien Südasiens, Vol. 3, 37-40.

Dangi, M. B., Pretz, C. R., Urynowicz, M. A., Gerow, K. G., \& Reddy, J. M. (2011). Municipal solid waste generation in Kathmandu, Nepal. Journal of Environmental Management, 92, 240-249. https://doi.org/10.1016/j.jenvman.2010.09.005.

Dar, P. A., Reshi, Z. A., \& Shah, M. A. (2015). Roads act as corridors for the spread of alien plant species in the mountainous regions: A case study of Kashmir Valley, India. Tropical Ecology, 56(2), 49-56.

Das, P. (2008). Evolution of the road network in Northeast India: Drivers and brakes. Strategic Analysis, 33(1), 101-116.

Das, A., \& Kumar, M. (2015a). Arsenic enrichment in the groundwater of Diphu, Northeast India: Coupled application of major ion chemistry, speciation modeling, and multivariate statistical techniques. Clean-Soil Air Water, 43, 1501-1513.

Das, A., \& Kumar, M. (2015b). Arsenic enrichment in the groundwater of Diphu, Northeast India: Coupled application of major ion chemistry, speciation modeling, and multivariate statistical techniques. Clean-Soil Air Water, 43, 1501-1513.

De Schutter, O. (2010): Addressing concentration in food supply chains. In The role of competition law in tackling the abuse of buyer power. Special Rapport on the Right to Food. Briefing Note 03, December 2010. http://www.ohchr.org/Documents/Issues/Food/ BN3_SRRTF_Competition_ENGLISH.pdf.

Debyani, M. R., \& Neeta, S. (2012). GM crops in India with reference to Bt cotton: Opportunities and challenges. Journal of Environmental Research and Development, 7, 188-193.

DeFries, R. S., et al. (2010). Deforestation driven by urban population growth and agricultural trade in the twenty-first century. Nature Geoscience, 3(3), 178-181. http://www.nature.com/doifinder/10. 1038/ngeo756.

Delmer, D. P. (2005). Agriculture in the developing world: Connecting innovation in plant research to downstream application. Proceedings of the National Academy of Sciences, 102, 15739-15746.

Demenge, J. (2012). The political ecology of road construction in Ladakh. University of Sussex.

DeSherbinin, A., et al. (2007). Population and Environment. Annual Review of Environment and Resources, 32(1), 345-373. http:// www.ncbi.nlm.nih.gov/pmc/articles/PMC2792934/.

Devi, H. T., Ghosh, C. K., Datta, B. K., Dasgupta, R., Mukhopadhayay, S. K., Mandal, T. K., et al. (2010). Arsenic exposure on bovine health and environmental pollution with special emphasis on groundwater system in Manipur. Indian Journal of Animal Sciences, 80, 642-646.

Dhanai, R., Negi, R. S., Singh, S., \& Parmar, M. K. (2015). Fuelwood consumption by villagers in different altitudinal gradient: A case of Takoligad watershed of Garhwal Himalaya, India. International Journal of Current Engineering and Technology, 5, 72-80.

Dietz, T., Rosa, E. A., \& York, R. (2007). Driving the human ecological footprint. Frontiers in Ecology and the Environment, 5 (1), 13-18. http://www.esajournals.org/doi/abs/10.1890/1540-9295 (2007)5[13:DTHEF]2.0.CO;2.

Ding, Y., Liu, S., Li, J., \& Shangguan, D. (2006). The retreat of glaciers in response to recent climate warming in Western China. Annals of Glaciology, 43, 97-105.

Ding, J., Mack, R. N., Lu, P., Ren, M., \& Huang, H. (2008). China's booming economy is sparking and accelerating biological invasions. BioScience, 58, 317-324.
Dobhal, P. K., Kohli, R. K., \& Batish, D. R. (2010). Evaluation of the impact of Lantana camara L. invasion, on four major woody shrubs, along Nayar river of Pauri Garhwal, in Uttarakhand Himalaya. International Journal of Biodiversity and Conservation, 2, 155-161.

Dobhal, P. K., Kohli, R. K., \& Batish, D. R. (2011). Impact of Lantana camara $\mathrm{L}$. invasion on riparian vegetation of Nayar region in Garhwal Himalayas (Uttarakhand, India). Journal of Ecology and The Natural Environment, 3, 11-22.

Dogra, K. S., Kohli, R. K., \& Sood, S. K. (2009). An assessment and impact of three invasive species in the Shivalik hills of Himachal Pradesh, India. International Journal of Biodiversity and Conservation, 1, 4-10.

Dong, S. K., Lassoie, J. P., Yan, Z. L., Sharma, E., Shrestha, K. K., \& Pariya, D. (2007). Indigenous rangeland resource management in the mountainous areas of northern Nepal: A case study from the Rasuwa District. The Rangeland Journal, 29, 149-160.

Dong, S. K., Lassoie, J., Shrestha, K. K., Zhaoli, Y., Sharma, E., \& Pariyar, D. (2009). Institutional development for sustainable rangeland resource and ecosystem management in mountainous areas of northern Nepal. Journal of Environmental Management, 90, 994-1003.

Dong, S. K., Wen, L., Zhu, L., \& Li, X. Y. (2010). Implication of coupled natural and human systems in sustainable rangeland ecosystem management in HKH. Frontier in Earth Science of China, 4(1), 42-50.

Donnelly, L. J. (2004). Geological investigations at a high altitude, remote coal mine on the Northwest Pakistan and Afghanistan frontier, Karakoram Himalaya. International Journal of Coal Geology, 60, 117-150.

Dorji, T. (2001). Sustainability of tourism in Bhutan. Journal of Bhutan Studies, 3, 84-104.

Duan, A. M., Wu, G. X., Zhang, Q., \& Liu, Y. M. (2006). New proofs of the recent climate warming over the Tibetan Plateau as a result of the increasing greenhouse gases emissions. Chinese Science Bulletin, 51(11), 1396-1400.

DWIDP. (2005). Disaster review 2004, Series XII. Kathmandu: Department of Water Induced Disaster Prevention, Nepal.

Evans A., Hanjra M. A., Jiang Y., Qadir M., \& Drechsel P. (2012). Water pollution in Asia: The urgent need for prevention and monitoring. Water Quality. Global Water Forum. UNESCO.

Fang, Y., \& Ying, B. (2016). Spatial distribution of mountainous regions and classifications of economic development in China. Journal of Mountain Science, 13(6), 1120-1138.

Fischer, G., Shah, M., \& van Velthuizen, H. (2002). Climate change and agricultural vulnerability. Vienna, IIASA. http://adapts.nl/ perch/resources/climateagri.pdf.

Fischer, K., Ekener-Petersen, E., Rydhmer, L., \& Björnberg, K. E. (2015). Social impacts of GM crops in agriculture: A systematic literature review. Sustainability, 7(7), 8598-8620.

Foggin, J. M. (2008). Depopulating the Tibetan grasslands: National policies and perspectives for the future of Tibetan herders in Qinghai Province, China. Mountain Research and Development, 28 (1), 26-31.

Foggin, J. M. (2016). Conservation issues: Mountain ecosystems. Earth Systems \& Environmental Sciences (Reference Module online). Science Direct, Elsevier Publishing Company. https://doi.org/10. 1016/b978-0-12-409548-9.09199-5.

Foggin, J. M. (2018). Environmental conservation in the Tibetan Plateau region: Lessons for China's Belt \& Road Initiative in the mountains of Central Asia. Land, 7, 52. http://www.mdpi.com/ 2073-445X/7/2/52.

Foggin, J. M., \& Phillips, J. (2013). Horizontal policy analysis: A tool to promote sustainable livelihoods development with implications for ecological resettlement and other major development programs 
in the Tibetan Plateau region. In Å. Kolås, \& Zhaluo (Eds.), Pastoralism in contemporary China: Policy and practice (pp. 3-30). Beijing, China: Social Science Academic Press. [In Chinese].

Forster, D., Andres, C., Verma, R., Zundel, C., Messmer, M. M., et al. (2013). Yield and economic performance of organic and conventional cotton-based farming systems-Results from a field trial in India. PLoS One, 8(12), e81039. https://doi.org/10.1371/journal. pone.0081039.

Fort, M. (2017): The mountain environments facing climate change: Disorders or/and opportunities? In Lecture at the International Conference of LabEx ITEM: The Mountain Environments Facing Climate Change: Disorders or/ and Opportunities?, 11-13 Jan. 2017, Grenoble.

Fort, M., \& Adhikari, B. R. (2018). Pokhara (central Nepal): A dramatic, yet geomorphologically active environment vs. a dynamic, rapidly developing city. In M. J. Thornbush, \& C. D. Allen (Eds.), Urban geomorphology: landforms and processes in cities. Chap. 9. Elsevier. (forthcoming).

Fourastie, J. (1989 [1949]). Le Grand Espoir du XXe siècle. Progrès technique, progrès économique, progrès social. Paris: PUF.

Frey, K. E., Ghimire, B., \& Panday, P. K. (2011). Detection of the timing and duration of snowmelt in the Hindu Kush-Himalaya using QuikSCAT, 2000-2008. Environmental Research Letters, 6(2), 24007-24013.

Fujita, K., Suzuki, R., Nuimura, T., \& Sakai, A. (2008). Performance of ASTER and SRTM DEMs, and their potential for assessing glacial lakes in the Lunana region, Bhutan Himalaya. Journal of Glaciology, 54, 220-228.

Fukui, K., Fujii, Y., Ageta, Y., \& Asahi, K. (2007). Changes in the lower limit of mountain permafrost between 1973 and 2004 in the Khumbu Himal, the Nepal Himalayas. Global and Planetary Change, 55(4), 251-256.

Fürer-Haimendorf, C. V. (1975). Himalayan traders: Life in highland Nepal. London: Cox \& Wyman Ltd.

Fusun, S., Jinniu, W., Tao, L., Yan, W., Haixia, G., \& Ning, W. (2013). Effects of different types of vegetation recovery on runoff and soil erosion on a Wenchuan earthquake-triggered landslide, China. Journal of Soil and Water Conservation, 68(2), 138-145.

Gautam, B. P. (2011). Tourism and economic growth in Nepal. NRB Economic Review, 23(2), 18-29.

Gayden, T., Cadenas, A. M., Regueiro, M., Singh, N. B., Zhivotovsky, L. A., Underhill, P. A., et al. (2007). The Himalayas as a directional barrier to gene flow. The American Journal of Human Genetics, 80 (5), 884-894.

Gerlitz, J. Y., Hunzai, K., Hoermann, B. (2012). Mountain Poverty in the Hindu-Kush Himalayas. Canadian Journal of Development Studies, 33, 250-265.

Gerlitz, J.-Y., et al. (2015). A multidimensional poverty measure for the Hindu Kush-Himalayas, applied to selected districts in Nepal. Mountain Research and Development, 35(3), 278-288.

Gerwin, M., \& Bergmann, C. (2012). Geopolitical relations and regional restructuring: The case of the Kumaon Himalaya, India. Erdkunde, 91-107.

Ghosh, P. (2007). Urbanization-A potential threat to the fragile Himalayan environment. Current Science, 93(2), 126.

Gilani, H., Shrestha, H. L., Murthy, M. S. R., Phuntso, P., Pradhan, S., Bajracharya, B., et al. (2015). Decadal land cover change dynamics in Bhutan. Journal of Environmental Management, 148, 91-100.

Gilani H., Qamer F. M., Sohail M., Uddin K., Jain A., \& Wu, N. (2017). Review of ecosystem monitoring in Nepal and evolving earth observation technologies. In A. N. Li, W. Deng, \& W. Zhao (Eds.), Land cover change and its eco-environmental responses in Nepal (pp. 165-184). Singapore: Springer Nature.

Glorioso, R. S., \& Moss, L. A. G. (2006). Santa Fe, a fading dream: 1986 profile and 2005 postscript. In L. A. G. Moss (Ed.), The amenity migrants: Seeking and sustaining mountains and their cultures. Chap. 5: 73-93. Wallingford/UK: CABI.

GoIRA (Government of the Islamic Republic of Afghanistan). (2015). The state of Afghan cities 2015, Vol. 1. Kabul: GoIRA. http:// unhabitat.org/books/soac2015/ (accessed 4.9.2016).

Goodall, S. K. (2004). Rural-to-urban migration and urbanization in Leh, Ladakh. Mountain Research and Development, 24(3), 220227.

Grabherr, G., Gottfried, M., \& Pauli, H. (1994). Climate effects on mountain plants. Nature, 369(6480), 448.

Grocke, M. U. (2016). On the road to better health? Impacts of new market access on food security, nutrition, and well-being in Nepal, Himalaya. Doctoral dissertation, University of Montana.

Gruschke, A. (2011). From Yak Herders to Yartsa Traders. Tibetan Nomads and new market options in Qinghai's Yushu region. China Tibetology, 3, 95-118.

Global Witness. (2015). Jade: Myanmar's big state secret. London: Global Witness.

GSMA Intelligence. (2015). Mobile internet usage challenges in AsiaAwareness, literacy and local content.

Guha-Sapir, D., Hoyois, P., \& Below, R. (2016). Annual disaster statistical review 2015: The numbers and trends. Brussels, Belgium: CRED.

Gujja, B., Chatterjee, A., Gautam, P., \& Chandan, P. (2003). Wetlands and lakes at the top of the world. Mountain Research and Development, 23(3), 219-221.

Gurung, J., Ishiga, H., \& Khadka, M. S. (2005). Geological and geochemical examination of arsenic contamination in groundwater in the Holocene Terai Basin, Nepal. Environmental Geology, 49, 98-113.

Gyawali, S., Sthapit, B., Joshi, B. K., Mudwari, A., \& Bajracharya, J. (2006). Participatory plant breeding: A strategy of on-farm conservation and improvement of landraces. In B. R. Sthapit, P. Shrestha, \& M. P. Upadhyay (Eds.), On-farm management of agricultural biodiversity in Nepal: Good practices. NARC/LI-BIRD/ Bioversity International, Nepal.

Haigh, M., \& Rawat, J. S. (2011). Landslide causes: Human impacts on a Himalayan landslide swarm. Belgian Journal of Geography, 3-4, 201-220.

Handa, O. C. (2001). Buddhist Western Himalaya: A politico-religious history (pp. 1-400). Indus Publishing Company.

Hanjra, M. A., \& Qureshi, M. E. (2010). Global water crisis and future food security in an era of climate change. Food Policy, 35(5), 365377.

Harris, R. B. (2010). Rangeland degradation on the Qinghai-Tibetan Plateau: A review of the evidence of its magnitude and causes. Journal of Arid Environments, 74, 1-12.

Harris, T. (2013). Trading places: New economic geographies across Himalayan borderlands. Political Geography, 35, 60-68.

Hart, R., Salick, J., Ranjitkar, S., \& Xu, J. (2014). Herbarium specimens show contrasting phenological responses to Himalayan climate. Proceedings of the National Academy of Sciences of the United States of America, 111(29), 10615.

Harvey, D. (1982, 2006). The limits to capital. London, New York: Verso.

Hasan, A. B., Kabir, S., Reza, A., Zaman, M. N., Ahsan, M. A., Akbor, M. A., et al. (2013). Trace metals pollution in seawater and groundwater in the ship breaking area of Sitakund Upazilla, Chittagong, Bangladesh. Marine Pollution Bulletin, 71, 317-324.

Hasnain, S. I. (2007). Impact of climate change on Himalayan glaciers and Glacier lakes. In Proceedings of Taal, World Lake Conference.

Ho, P. (2001). Rangeland degradation in North China revisited? A Preliminary statistical analysis to validate non-equilibrium range ecology. Journal of Development Studies, 37, 99-133. https:// papers.ssrn.com/sol3/papers.cfm?abstract_id=2168755. 
Hodge, H. N. (1991). Ancient futures: Learning from Ladakh. Oxford: Oxford University Press.

Hodges, J., Foggin, J. M., Long, R. J., \& Zhaxi, G. (2014). Globalisation and the sustainability of farmers, livestock-keepers, pastoralists and fragile habitats. Biodiversity 15(2-3), 109-118. https://doi.org/10.1080/14888386.2014.931247.

Hoermann, B., \& Kollmair, M. (2009). Labour migration and remittances in the Hindu Kush-Himalayan region. Kathmandu: ICIMOD.

Hoon, V. (1996). Living on the move. Bhotiya tribe of Himalaya (pp. 191-205). New Delhi: Sage Publishers.

Howard, C. A. (2013). Himalayan journeys: A mobile ethnography and philosophical anthropology: a thesis submitted in partial fulfilment of the requirements for the degree of doctor of philosophy in social anthropology. Doctoral dissertation. Massey University, Auckland.

Hsiang, S. M., Meng, K. C., \& Cane, M. A. (2011). Civil conflicts are associated with the global climate. Nature, 476(7361), 438.

Huang, X., Sillanpaa, M., Duo, B., \& Gjessing, E. T. (2008). Water quality in the Tibetan Plateau: Metal contents of four selected rivers. Environmental Pollution, 156, 270-277.

Huang, X., Sillanpaa, M., Giessing, E. T., \& Vogt, R. D. (2009). Water quality in the Tibetan Plateau: Major ions and trace elements in the headwaters of four major Asian rivers. Science of the Total Environment, 407, 6242-6254.

Huang, X., Sillanpaa, M., Giessing, E. T., Peranniemi, S., \& Vogt, R. D. (2010). Environmental impact of mining activities on the surface water quality in Tibet: Gyama valley. Science of the Total Environment, 408, 4177-4184.

Hulme, P. E., Pysek, P., Jaros, V., Pergl, J., \& Schaffner, V. M. (2013). Bias and error in understanding plant invasion impacts. Trends in Ecology \& Evolution, 28, 212-218.

Husen M. A (2014). Impact of invasive alien fish, Nile Tilapia (Oreochromis niloticus) on native fish catches of sub-tropical lakes (Phewa, Begnas and Rupa) of Pokhara Valley, Nepal. In G. J. Thapa, N. Subedi, M. R. Pandey, S. K. Thapa, N. R. Chapagain, A. Rana (Eds.), Proceedings of the international conference on invasive alien species management. National Trust for Nature Conservation, Nepal.

ICIMOD. (2009). Mountain biodiversity and climate change. Kathmandu: ICIMOD.

ICIMOD. (2011). Glacial lakes and glacial lake outburst floods in Nepal. Kathmandu: ICIMOD.

ICIMOD. (2012). A strategy and results framework for ICIMOD. Kathmandu: ICIMOD.

Immerzeel, W. W., van Beek, L. P., \& Bierkens, M. F. (2010). Climate change will affect the Asian water towers. Science, 328(5984), $1382-1385$.

Ingole, N. A., Ram, R. N., Ranjan, R., \& Shankhwar, A. K. (2015). Advance application of geospatial technology for fisheries perspective in Tarai region of Himalayan state of Uttarakhand. Sustainable Water Resources Management, 1(2), 181-187. International Disaster Database: www.cred.be.

IUCN (2017). Programmatic strategy for strengthening the presence of IUCN in Asia. Version: May 2017.

IUCN Pakistan. (2009). Environmental fiscal reform in Abbottabad: Mining and quarrying (VI +26 pp.). IUCN Pakistan, Islamabad, Pakistan.

Ives, J. (2013). Sustainable mountain development - Getting the facts right Jack D. Ives $(x v+293$ pp.). Lalitpur, Nepal: Himalayan Association for the Advancement of Science, 2013.

Ives, J. D., Shrestha, R. B., \& Mool, Pradeep K. (2010). Formation of Glacial lakes in the Hindu Kush-Himalayas and GLOF risk assessment. Kathmandu: ICIMOD.

Jacquemet, E. (2017). Réinventer le Khumbu: la société sherpa à l'ère du « Yak Donald's ». Conférence internationale: La montagne, territoire d'innovation, Jan. 2017, Grenoble, France. https://halshs. archives-ouvertes.fr/halshs-01446577/document 14 Feb. 2017.

Jacquemet, E. (2018). Réinventer le Khumbu: la société sherpa à l'ère du « Yak Donald's ». In M.-C. Fourny (Ed.), La montagne, territoire d'innovation. LabEx ITEM, Collection 'Montagne et Innovation'. Grenoble: Presses Universitaires de Grenoble (forthcoming).

Jeelani, G., \& Shah, A. Q. (2006). Geochemical characteristics of water and sediment from the Dal Lake, Kashmir Himalaya: Constraints on weathering and anthropogenic activity. Environmental Geology, 50, $12-23$.

Jin, W. (2015). Tibet as recipient of assistance and its sustainable development. Nottingham.

Jin, J., Lu, S., Li, S., \& Miller, L. N. (2010). Impact of land use change on the local climate over the Tibetan Plateau. Adv: Meteorol. https://doi.org/10.1155/2010/837480.

Jodha, N. S. (2000). Poverty alleviation and sustainable development in mountain areas: Role of highland-lowland links in the context of rapid globalisation. In M. Banskota, T. S. Papola, \& J. Richter (Eds.), Growth, poverty alleviation, and sustainable resource management in the mountain areas of South Asia (pp. 541-570). Deutsche Stiftung fur internationale Entwicklung: Feldafing.

Jodha, N. S. (2005). Economic globalisation and its repercussions for Fragile mountains and communities in the Himalayas. In U. M. Huber, H. K. M. Bugmann, \& M. A. Reasoner (Eds.), Global change and mountain regions: An overview of current knowledge (pp. 583-591). Dordrecht: Springer Netherlands.

Johnson, S. T., Agarwal, R. K., \& Agarwal, A. (2013). Non-timber forest products as a source of livelihood option for forest dwellers: Role of society, herbal industries and government agencies. Current Science, 104, 440-443.

Joshi, R., Nailwal, T. K., Tewari, L. M., \& Shukla, A. (2009). Exploring biotechnology for conserving Himalayan biodiversity. Life Science Journal, 7(3), 20-28.

Juyal, D., Thawani, V., Thaledi, S., \& Joshi, M. (2014). Ethnomedical properties of Taxus wallichiana Zucc. (Himalayan Yew). Journal of Traditional and Complementary Medicine, 4(3), 159-161.

Kala, C. P. (2014). Changes in traditional agriculture ecosystem in Rawain Valley of Uttarakhand state in India. Applied Ecology and Environmental Sciences, 2(4), 90-93.

Kalman, B. (2009). What is culture? Crabtree Publishing Company.

Kannan, R., Shackleton, M. C., \& Shaanker, U. R. (2013). Reconstructing the history of introduction and spread of the invasive species, Lantana, at three spatial scales in India. Biological Invasions, 15, 1287-1302.

Kannel, P. R., Kanel, S. R., Lee, S., \& Lee, Y. S. (2011). Chemometrics in assessment of seasonal variation of water quality in fresh water systems. Environmental Monitoring and Assessment, 174, 529-545.

Karkey, A., Jombart, T., Walker, A. W., Thompson, C. N., Torres, A., Dongol, S., et al. (2016). The ecological dynamics of fecal contamination and Salmonella Typhi and Salmonella Paratyphi A in municipal Kathmandu drinking water. PLoS Neglected Tropical Diseases, 10, 18.

Karki, M., et al. (2012) Sustainable mountain development 1992, 2012, and beyond Rio +20 . Assessment report for the Hindu Kush Himalayan region. Kathmandu: ICIMOD.

Karrar, H. H. (2013). Merchants, Markets, and the State. Critical Asian Studies, 45(3), 459-480. https://doi.org/10.1080/14672715.2013. 829315.

Katuwal, H. B., Neupane, K. R., Adhikari, D., Sharma, M., \& Thapa, S. (2015). Pangolins in eastern Nepal: Trade and ethno-medicinal importance. Journal of Threatened Taxa, 7, 7563-7567.

Kaur, R., Joshi, S. P., \& Srivastava, M. M. (2012). Natural resource degradation in three sub-watersheds of river Tons, Uttarakhand, India. Tropical Ecology, 53(3), 333-343. 
Khan, H. A., \& Weiss, J. (2006). Infrastructure for regional Co-operation. In Paper Presented in the Joint Workshop of ADBI and IDB in Seoul, Nov. 15-17.

Khan, A. M., Ali, Z., Shelly, S. Y., Ahmad, Z., \& Mirza, M. R. (2011). Aliens; A catastrophe for native fresh water fish diversity in Pakistan. The Journal of Animal and Plant Sciences, 21, 435-440.

Khan, B., Ablimit, A., Khan, G., Jasra, A. W., Ali, H., Ali, R., et al. (2016). Abundance, distribution and conservation status of Siberian ibex, Marco Polo and Blue sheep in Karakoram-Pamir Mountain area. Journal of King Saud University-Science, 28, 216-225.

Khawas, V. (2007). Environmental challenges and human security in the Himalaya. In Paper at the National Seminar "Himalayas in the New Millennium: Environment, Society, Economy and Polity", January 2007. Centre for Himalayan Studies, North Bengal University, Darjeeling. http://www.mtnforum.org/sites/default/files/ publication/files/526.pdf (accessed 4.9.2016).

Khuroo, A. A., Rashid, I., Reshi, Z., Dar, G. H., \& Wafai, B. A. (2007). The alien flora of Kashmir Himalaya. Biological Invasions, 9, 269292.

Khuroo, A. A., Weber, E., Malik, A. H., Dar, G. H., \& Reshi, Z. A. (2010). Taxonomic and biogeographic patterns in the native and alien flora of Kashmir Himalaya, India. Nordic Journal of Botany, 28, 685-696.

Khuroo, A. A., Weber, E., Malik, A. H., Reshi, Z. A., \& Dar, G. H. (2011). Altitudinal distribution patterns of the native and alien woody flora in Kashmir Himalaya, India. Environmental Research, 111, 967-977.

Khuroo, A. A., Reshi, Z. A., Malik, A. H., Weber, E., Rashid, I., \& Dar, G. H. (2012). Alien flora of India: Taxonomic composition, invasion status and biogeographic affiliations. Biological Invasions, 14, 99-113.

Kien, G. (2009). Actor-network theory: Translation as material culture. In P. Vannini (Ed.), Material culture and technology in everyday life: Ethnographic approaches (pp. 27-44). New York: Peter Lang Publishing.

Kohler, T., et al. (Eds.). (2001). Mountains of the world: Mountains, energy, and transport. Bern, Switzerland: Mountain Agenda.

Kohli, R. K., Batish, D. R., Singh, H. P., \& Dogra, K. S. (2006). Status, invasiveness and environmental threats of three tropical American invasive weeds (Parthenium hysterophorus L., Ageratum conyzoides L., Lantana camara L.) in India. Biological Invasions, 8, 1501-1510.

Kosaka, Y., Saikia, B., Mingki, T., Tag, H., Riba, T., \& Ando, K. (2010). Roadside distribution patterns of invasive alien plants along an altitudinal gradient in Arunachal Himalaya, India. Mountain Research and Development, 30, 252-258.

Kreutzmann, H. (1991). The Karakoram highway: Impact of road construction on mountain societies. Modern Asian Studies, 25(4), 711-736.

Kreutzmann, H. (1993). Challenge and response in the Karakoram: Socioeconomic transformation in Hunza, Northern Areas, Pakistan. Mountain Research and Development, 13(1), 19-39.

Kreutzmann, H. (2004). Accessibility for High Asia: Comparative perspectives on northern Pakistan's traffic infrastructure and linkages with its neighbours in the Hindu-Kush-Karakoram-Himalaya. Journal of Mountain Science, 1(3), 193-210.

Krugman, P. R. (1991). Increasing returns and economic geography. Journal of Political Economy, 99(3), 483-499.

Kumar, K. R., Sahai, A. K., Kumar, K. K., Patwardhan, S. K., Mishra, P. K., Revadekar, J. V., et al. (2006). High-resolution climate change scenarios for India for the 21st century. Current Science, 9 (3), 334-345.

Kumar, V. P., Rajpoot, A., Mukesh, S. M., Kumar, D., \& Goyal, S. P. (2016). Illegal trade of Indian Pangolin (Manis crassicaudata):
Genetic study from scales based on mitochondrial genes. Egyptian Journal of Forensic Sciences. http://dx.doi.org/10.1016/j.

Kunwar, R. M. (2003). Invasive alien plants and Eupatorium: Biodiversity and livelihood. Himalayan Journal of Sciences, 1, 129-133.

Kunwar, R. M., \& Acharya, R. P. (2013). Impact assessment of invasive plant species in selected ecosystems of Bhadaure Tamagi $V D C$. IUCN Nepal: Kaski.

Lama, G., Ozawa, M., \& Lama, P. (2010). Geographic isolation and poverty among Indigenous peoples in Nepal. The Himalayan Research Papers Archive. https://ejournals.unm.edu/index.php/nsc/ article/view/624. Accessed 11 Sept. 11, 2016.

LeBaron, Michelle. (2003). Bridging Cultural Conflicts: A New Approach for a Changing World. Jossey-Bass, San Francisco, CA.

Le Monde (23 May 2015) Manifestation au Burkina Faso contre les OGM de Monsanto. La société civile burkinabè organise une marche à Ouagadougou pour défendre sa souveraineté alimentaire, dans le cadre de la journée mondiale de résistance aux OGM. http:// www.lemonde.fr/afrique/article/2015/05/23/manifestation-auburkina-faso-contre-les-ogm-de-monsanto_4639357_3212.html. Accessed 12 Dec. 2017.

Leimgruber, P., Kelly, D. S., Steininger, M., Brunner, J., Müller, T., \& Songer, M. (2005). Forest cover change patterns in Myanmar (Burma) 1990-2000. Environmental Conservation, 32(4), 356-364.

$\mathrm{Li}, \mathrm{T}$. (1990). Landslide management in the mountain area of China (p. 50), ICIMOD Kathmandu, Occasion Paper no. 15.

Li, J. J., \& Fang, X. M. (1999). Uplift of the Tibetan Plateau and environmental changes. Chinese Science Bulletin, 44(23), 21172124.

Li, J., \& Lu, Z. (2014). Snow leopard poaching and trade in China 2000-2013. Biological Conservation, 176, 207-211.

Li Q and Xue Y. (2010). Simulated impacts of land cover change on summer climate in the Tibetan Plateau. Environ Res Lett, 5, 15102. http://doi.org/10.1088/1748-9326/5/1/015102.

Li, J., Wang, W., Hu, G., \& Wei, Z. (2010). Changes in ecosystem service values in Zoige Plateau, China. Agric. Ecosyst. Environ., 139, 766-770.

Li, Y., Gongbuzeren, B., \& Li, W. J. (2014). A review of China's rangeland management policies. IIED Country Report. IIED, London.

Li, C. D., Zhang, Q. G., Kang, S. C., Liu, Y. Q., Huang, J., Liu, X. B., et al. (2015). Distribution and enrichment of mercury in Tibetan lake waters and their relations with the natural environment. Environmental Science and Pollution Research, 22, 12490-12500.

Li, D. G., Li, Z. X., Hu, J. S., Lin, Z. X., \& Li, X. F. (2016). Polymorphism analysis of multi-parent advanced generation inter-cross (MAGIC) populations of upland cotton developed in China. Genetics and Molecular Research, 15(4), gmr15048759.

Li, A. N., Deng, W., \& Zhao, W. (Eds.). (2017). Land cover change and its eco-environmental responses in Nepal. Singapore: Springer Nature.

Liu, J., et al. (2009). Climate warming and growth of high-elevation inland lakes on the Tibetan Plateau. Global and Planetary Change, 67(3-4), 209-217.

Liu, J., Kang, S., Gong, T., \& Lu, A. (2010). Growth of a high-elevation large inland lake, associated with climate change and permafrost degradation in Tibet. Hydrology and Earth System Sciences, 14(3), 481-489.

Liu, L., Zhang, X. Y., \& Zhong, T. Y. (2016a). Pollution and health risk assessment of heavy metals in urban soil in China. Human and Ecological Risk Assessment, 22, 424-434.

Liu, Z., Jiang, Z., Fang, H., Li, C., Mi, A., Chen, J., et al. (2016b). Perception, price and preference: Consumption and protection of wild animals used in traditional medicine. PLoS One, 11(3), e0145901. https://doi.org/10.1371/journal.pone.0145901. 
Loewen, M., Kang, S., Armstrong, D., Zhang, Q., Tomy, G., \& Wang, F. (2007). Atmospheric transport of mercury to the Tibetan Plateau. Environmental Science and Technology, 41, 7632-7638.

Lowe, S., Browne, M., Boudjelas, S., De Poorter, M. (2000). 100 of the World's worst invasive alien species: A selection from the global invasive species database (12 pp). Published by The Invasive Species Specialist Group (ISSG) a specialist group of the Species Survival Commission (SSC) of the World Conservation Union (IUCN).

Lu, T., Zeng, H. C., Luo, Y., Wang, Q., Shi, F. S., Sun, G., et al. (2012). Monitoring vegetation recovery after China's May 2008 Wenchuan earthquake using Landsat TM time-series data: A case study in Mao County. Ecological Research, 27, 955-966.

Luo, J., Tang, R. G., She, J., Chen, Y. C., Gong, Y. W., Zhou, J., et al. (2013). The chromium in timberline forests in the eastern Tibetan Plateau. Environmental Science: Processes and Impacts, 15, 19301937.

Luo, J., Tang, R. G., Sun, S. Q., Yang, D. D., She, J., \& Yang, P. J. (2015). Lead distribution and possible sources along vertical zone spectrum of typical ecosystems in the Gongga Mountain, eastern Tibetan Plateau. Atmospheric Environment, 115, 132-140.

Lutz, A. F., Immerzeel, W. W., Shrestha, A. B., \& Bierkens, M. F. P. (2014). Consistent increase in High Asia's runoff due to increasing glacier melt and precipitation. Nature Climate Change, 4 (7), 587-592.

Maikhuri, R. K., Rawat, L. S., Negi, V. S., Purohit, V. K., Rao, K. S., \& Saxena, K. G. (2011). Managing natural resources through simple and appropriate technological interventions for sustainable mountain development. Current Science, 100(7), 992-997.

Manandhar, S., Xenarios, S., Schmidt-Vogt, D., Hergarten C., \& Foggin, M. (2018). Climate vulnerability and adaptive capacity of mountain societies in Central Asia. Research Report 1, Mountain Societies Research Institute, University of Central Asia, Bishkek, Kyrgyzstan. http://ucentralasia.org/Research/Item/1578.

Manfré, L. A., Hirata, E., Silva, J. B., Shinohara, E. J., Giannotti, M. A., Larocca, A. P. C., et al. (2012). An analysis of geospatial technologies for risk and natural disaster management. ISPRS International Journal of Geo-Information, 1, 166-185. https://doi. org/10.3390/ijgi1020166.

Marshall, A. (1890). Principles of economics. London: Macmillan.

Masoodi, A., \& Khan, F. A. (2012). Invasion of alligator weed (Alternanthera philoxeroides) in Wular Lake, Kashmir, India. Aquatic Invasions, 7, 143-146.

McCauley, M. (2016). Afghanistan and central Asia: A modern history (pp. 1-51). London: Routledge.

Merz, J., Nakarmi, G., Shrestha, S., Dahal, B. M., Dongol, B. S., Schaffner, M., et al. (2004). Public water sources in rural watersheds of Nepal's Middle Mountains: Issues and constraints. Environmental Management, 34, 26-37.

Messerli, B., \& Ives, J. D. (1997). Mountains of the world: A global priority. New York: Parthenon.

Ministry of Science, Technology and Environment, Government of Nepal. (2015). Nepal earthquake 2015: Rapid environmental assessment. Kathmandu.

Moors, E. J., \& Stoffel, M. (2013). Changing monsoon patterns, snow and glacial melt, its impacts and adaptation options in northern India: Synthesis. Science of the Total Environment, 468-469, 162167.

Morelli, J. (2011). Environmental sustainability: A definition for environmental professionals. Journal of Environmental Sustainability, 1. Rochester Institute of Technology.

Moriconi-Ebrard, F. (1993). L'urbanisation du monde depuis 1950 Paris: Anthropos.
Moss, L. A. G., \& Glorioso, R. (Eds.). (2014). Global amenity migration: Transforming rural culture economy and landscape. Kaslo, British Columbia: The New Ecology Press.

Mukul, S. A., Uddin, M. B., Rashid, A. Z. M. M., \& Fox, J. (2010). Integrating livelihoods and conservation in protected areas: Understanding the role and stakeholder views on prospects for non-timber forest products, a Bangladesh case study. International Journal of Sustainable Development and World Ecology, 17, 180-188.

Nabulo, G., Young, S. D., \& Black, C. R. (2010). Assessing risk to human health from tropical leafy vegetables grown on contaminated urban soils. Science of the Total Environment, 408, 5338-5351.

Naitthani, P., \& Kainthola, S. (2015). Impact of conservation and development on the Vicinity of Nanda Devi National Park in the North India. JAR/RGA (Journal of Alpine Research/Revue de Géographie Alpine), 103(3). http://rga.revues.org/3100.

Najar, I. A., \& Basheer, A. (2012). Assessment of seasonal variation in water quality of Dal Lake (Kashmir, India) using multivariate statistical techniques. In C. A. Brebbia (Ed.), Water pollution Xi. WIT transactions on ecology and the environment (pp. 123-134). Southampton: Wit Press.

Najar, I. A., \& Khan, A. B. (2012). Assessment of water quality and identification of pollution sources of three lakes in Kashmir, India, using multivariate analysis. Environmental Earth Sciences, 66, 2367-2378.

Narain, V., \& Singh, A. K. (2017): Lost in transition: Perspectives, processes and transformations in (Peri) urbanizing India. In Paper Presented at Asian Regional Conference on Peri-Urbanization: Emerging Issues and Practices, Tongji University, Shanghai, China. 8-10 May 2017.

Negi, V. S., Maikhuri, R. K., \& Rawat, L. S. (2011). Non-timber forest products (NTFPs): A viable option for biodiversity conservation and livelihood enhancement in central Himalaya. Biodiversity and Conservation, 20, 545-559.

Negi, G. C. S., Samal, P. K., Kuniyal, J. C., Kothyar, B. P., Sharma, R. K., \& Dhyani, P. P. (2012). Impacts of climate change on western Himalayan mountain ecosystems: An overview. Tropical Ecology, 53, 345-356.

Nelson, G. C., Bennett, E., Berhe, A. A., Cassman, K., DeFries, R., Dietz, T., et al. (2006). Anthropogenic drivers of ecosystem change: An overview. Ecology and Society, 11(2), 29.

Nepal, S. (2005). Tourism and remote mountain settlements: Spatial and temporal development of tourist infrastructure in the Mt Everest region, Nepal. Tourism Geographies: An International Journal of Tourism Space, Place and Environment, 7, 205-227.

Nepal, S. (2011). Mountain tourism and climate change: Implications for the Nepal Himalaya. Nepal Tourism \& Development Review, 1, 1-14.

Nepal, R., \& Henning, T. (2013). Remittances and livelihood strategies: A case study in Eastern Nepal. Kassel: Kassel University Press.

Nepal, S., \& Shrestha, A. B. (2015). Impact of climate change on the hydrological regime of the Indus, Ganges and Brahmaputra river basins: A review of the literature. International Journal of Water Resources Development, 31(2), 201-218.

Nibanupudi, H. K., \& Rawat, P. K. (2012). Environmental concerns for DRR in the HKH region. In A. K. Gupta \& S. S. Nair (Eds.), Ecosystem approach to disaster risk reduction. New Delhi: National Institute of Disaster Management.

Niggli, U. (2016). Interview with the research director of FibL, Urs Niggli, in the German daily journal TAZ and comments on it. http:// www.taz.de/!5290509/; https://www.organicconsumers.org/news/ crispr-gmo-technology-needs-no-regulation-says-usda; https:// translate.google.com/translate?hl=en\&sl=de\&u=; http://bio-markt. info/berichte/ein-interview-mit-folgen-fibl-direktor-urs-niggli-bringtmit-seiner-sicht-auf.html\&prev=search. Accessed 12 Dec. 2017. 
Nüsser, M. (Ed.). (2014). Large dams in Asia. Contested environments between technological hydroscapes and social resistance. Springer.

Olschak, B. C., Bührer, E. M., Gansser, A., \& Gruschke, A. (1987). Himalayas: Growing mountains, living myths, migrating peoples (pp. 1-20). New York: Facts on File Publishers.

Osman, K. T. (2014). Soil degradation, conservation and remediation. Dordrecht: Springer Netherlands. http://link.springer.com/10.1007/ 978-94-007-7590-9.

Padmanaban, G. (2003). Growth of biotechnology in India. Current Science, 85(6), 712-719.

Pandit, M. K. (2009). Other factors at work in the melting Himalaya: follow-up to $\mathrm{Xu}$ et al. Conservation Biology: The Journal of the Society for Conservation Biology, 23(6), 1346-1347.

Pathak, D., Gajurel, A. P., \& Mool, P. K. (2010). Climate change impacts on hazards in the eastern Himalayas. Kathmandu: ICIMOD.

Paudyal, S. (2012). Does tourism really matter for economic growth? Evidence from Nepal. Nepal Rastra Bank Economic Review, 24(1), 48-66.

Perlik, M. (2011). Alpine gentrification: The mountain village as a metropolitan neighborhood. JAR/RGA, 99(1). http://rga.revues.org/ 1370.

Perlik, M. (2018). The spatial and economic transformation of mountain regions. Mountains as indicators for a new quality of territorial disparities. Abington: Routledge (in preparation).

Piccio, L. (2015). India's 2015-16 foreign aid budget: Where the Money is going? DEVEX (blog). https://www.devex.com/news/ india-s-2015-16-foreign-aid-budget-where-the-money-is-going85666. Accessed 11 Sept. 2016.

Pimentel, D., McNair, S., Janecka, J., Wightman, J., Simmonds, C., O'Connell, C., et al. (2001). Economic and environmental threats of alien plant, animal, and microbe invasions. Agriculture, Ecosystems and Environment, 84, 1-20.

Pokhrel, D., \& Viraraghavan, T. (2005). Municipal solid waste management in Nepal: practices and challenges. Waste Management, 25, 555-562. https://doi.org/10.1016/j.wasman.2005.01.020.

Poudel, S., \& Shaw, R. (2015). Demographic changes, economic changes and livelihood changes in the HKH. In Mountain Hazards and Disaster Risk Reduction Part of the series Disaster Risk Reduction (pp 105-123).

Prakash, D., Verma, S., Bhatia, R. \& Tiwary, B. N. (2011). Risks and precautions of genetically modified organisms. ISRN Ecology. https://doi.org/10.5402/2011/369573.

Price, M. F. (2015). Mountains: A very short introduction (p. 152). Oxford, UK: Oxford University Press.

$\mathrm{Pu}$, J. C., et al. (2004). Fluctuations of the Glaciers on the Qinghai-Tibetan Plateau during the past century. Journal of Glaciology and Geocryology, 26(5), 517-522.

Public Eye. (2017). Europe missed the Boat. https://www.publiceye.ch/ en/media/press-release/patents_on_seeds_europe_misses_the_boat/. Accessed 12 Dec. 2017.

Pumain, D. (1999). Quel role pour les viles petites et moyennes des regions peripheriques? Revue de Géographie Alpine, 2, 167-184.

Pyšek, P., Jarosik, V., \& Pergl, J. (2011). Alien plants introduced by different pathways differ in invasion success: Unintentional introductions as a threat to natural areas. PLoS One, 6(9), e24890.

Qamer, F. M., Shehzad, K., Abbas, S., Murthy, M. S. R., Xi, C., Gilani, H., \& Bajracharya, B. (2016). Mapping deforestation and forest degradation patterns in Western Himalaya, Pakistan. Remote Sensing, 8(5).

Qasim, M., Hubacek, K., Termansen, M., \& Fleskens, L. (2013). Modelling land use change across elevation gradients in district Swat, Pakistan. Regional Environmental Change, 13, 567-581.
QBE Asia Pacific. (2017). Asia-Pacific ICT trends 2017-The future of the information communication and technology market in Asia-Pacific. Insurance Post \& QBE Insurance Group.

Qureshi, H., Arshad, M., \& Bibi, Y. (2014). Invasive flora of Pakistan: A critical analysis. International Journal of Biosciences, 4, 407424.

Rai, R. K., \& Rai, R. (2013). Assessing the temporal variation in the perceived effects of invasive plant species on rural livelihoods: A case of Mikania micrantha invasion in Nepal. Conservation Science, 1, 13-18.

Rai, R. K., Scarborough, H. (2015). Understanding the effects of the invasive plants on rural forest-dependent communities. Small-Scale Forestry, 14, 59-72.

Ramos, M. D. C. P., Ramos, N., \& Moreira, A. I. D. R. (2016). Climate change and forced environmental migration vulnerability of the Portuguese Coastline. Springer.

Rana, R. B., Garforth, C. J., Sthapit, B. R., Subedi, A., Chaudhary, P., \& Jarvis, D. I. (2007). On-farm management of rice genetic diversity: Understanding farmers' knowledge on rice ecosystems and varietal deployment. Plant Genetic Resources Newsletter, 152, 58-64.

Rana, J. C., Negi, K. S., Wani, S. A., Saxena, S., Pradheep, K., Kak, A., et al. (2009). Genetic resources of rice in the Western Himalayan region of India: Current status. Genetic Resources and Crop Evolution, 56(7), 963-973.

Rao K. S., Nautiyal N., Maikhuri R. K., \& Saxena K. G. (2000). Management conflicts in the Nanda Devi Biosphere Reserve, India. Mountain Research and Development, 20(4), 320-323. https://doi. org/10.1659/0276-4741(2000)020\%5b0320:mcitnd\%5d2.0.co;2.

Rashid, M., Abbas, S. H., \& Rehman, A. (2014). The status of highly alien invasive plants in Pakistan and their impact on the ecosystem: A review. Innovare Journal of Agriculture Science, 2, 1-4.

Rashid, I., Romshoo, S. A., Amin, M., Khanday, S. A., \& Chauhan, P. (2017). Linking human-biophysical interactions with the trophic status of Dal Lake, Kashmir Himalaya, India. Limnologica, 62, 8496.

Rasul, G., \& Sharma, B. (2015). The nexus approach to water-energyfood security: An option for adaptation to climate change. Climate Policy, 16(6), 682-702.

Rauf, S., da Silva, J. T., Khan, A. A., \& Naveed, A. (2010). Consequences of plant breeding on genetic diversity. International Journal of Plant Breeding, 41, 1-21.

Rautela, P., \& Karki, B. (2015). Impact of climate change on life and livelihood of Indigenous people of Higher Himalaya in Uttarakhand, India. American Journal of Environmental Protection, 3(4), 112-124.

Reddy, C. S., Sreelekshmi, S., Jha, C. S., \& Dadhwal, V. K. (2013). National assessment of forest fragmentation in India: Landscape indices as measures of the effects of fragmentation and forest cover change. Ecological Engineering, 60, 453-464.

Reinfeld, M. A. (2003). Tourism and the politics of cultural preservation: A case study of Bhutan. Journal of Public and International Affairs, 14, 1-26.

Reshi, Z. A., \& Khuroo, A. A. (2012). Alien plant invasions in India: Current status and management challenges. Proceedings of the National Academy of Sciences, India Section B: Biological Sciences, 82, 305-312.

Reshi, Z., Rashid, I., Ahmad, K., \& Wafai, B. A. (2008). Effect of invasion by Centaurea iberica on community assembly of a mountain grassland of Kashmir Himalaya, India. Tropical Ecology, 49, 147-156.

Riaz, A., Khan, S., Shah, M. T., Li, G., Gul, N., \& Shamshad, I. (2015). Mercury contamination in the blood, urine, hair and nails of the gold washers and its human health risk during extraction of placer 
gold along Gilgit. Pakistan: Hunza and Indus rivers in Gilgit-Baltistan.

Richardson, H. W. (1995). Economies and diseconomies of agglomeration. In H. Giersch (Ed.). Urban Agglomeration and Economic Growth (pp. 123-155). Springer.

Richardson, S. D., \& Reynolds, J. M. (2000). An overview of glacial hazards in the Himalayas. Quaternary International, 65-66, 31-47.

Rimal, B., Baral, H., Stork, N., Paudyal, K., \& Rijal, S. (2015). Growing city and rapid land use transition: Assessing multiple hazards and risks in the Pokhara Valley, Nepal. Land, 4(4), 957978.

Romanelli, C., et al. (2015). Connecting global priorities: Biodiversity and human health-A state of knowledge review. UNEP, CBD \& WHO.

Rousselot, Y. (2015). Upstream flows of water: From the Lesotho highlands to Metropolitan South Africa. Journal of Alpine Research | Revue de géographie alpine, 103-3. http://journals.openedition. org/rga/3023. Accessed 12 Dec. 2017.

Roy, R., Schmidt-Vogt, D., \& Myrholt, O. (2009). Humla development initiatives for better livelihoods in the face of isolation and conflict. Mountain Research and Development, 29(3), 211-219.

Rudel, T. K., et al. (2009). Changing drivers of deforestation and new opportunities for conservation. Conservation Biology, 23(6), 13961405. http://doi.wiley.com/10.1111/j.1523-1739.2009.01332.x.

Saba, D. S. (2001). Afghanistan: Environmental degradation in a fragile ecological setting. International Journal of Sustainable Development and World Ecology, 8, 279-289.

SafeNEPAL. (2016). The Gorkha Earthquake 2015: Economic impact on Nepal tourism. https://ohsnepal.wordpress.com/2016/03/09/parti-the-gorkha-earthquake-2015-economic-impact-on-nepal-tourism/.

Saini, R. K., Swain, S., Patra, A., Khanday, G. J., Gupta, H., Purushothaman, P., et al. (2008). Water chemistry of three Himalayan Lakes: Dal (Jammu \& Kashmir), Khajjiar (Himachal Pradesh) and Nainital (Uttarakhand). Himalayan Geology, 29, 6372.

Sakai, A. K., Allendorf, F., \& Holt, J. S. (2001). The population biology of invasive species. Annual Review of Ecology and Systematics, 32, 305-332.

Sang, W., Zhu, L., \& Axmacher, J. C. (2010). Invasion pattern of Eupatorium adenophorum Spreng in southern China. Biological Invasions, 12, 1721-1730.

Sann Oo, K. (2016). Relationship between climate change impact, migration and socioeconomic development. International Archives of the Photogrammetry Remote Sensing \& Spatial Information Sciences, XLI-B4, 743-746.

Sarma, K., \& Barik, S. K. (2011). Coal mining impact on vegetation of the Nokrek Biosphere Reserve, Meghalaya, India. Biodiversity, 12 (3), 154-164.

Saxena, K. G., Maikhuri, R. K., \& Rao, K. S. (2005). Changes in agricultural biodiversity: Implications for sustainable livelihood in the Himalaya. Journal of Mountain Science, 2(1), 23-31.

Schwarzenbach, R. P., Egli, T., Hofstetter, T. B., von Gunten, U., \& Wehrli, B. (2010). Global water pollution and human health. Annual Review of Environment and Resources, 35, 109-136.

Sekar, K. C. (2012). Invasive alien plants of Indian Himalayan region -Diversity and implication. American Journal of Plant Sciences, 3, 177-184.

Shabbir, A., \& Bajwa, R. (2006). Distribution of parthenium weed (Parthenium hysterophorus L.), an alien invasive weed species threatening the biodiversity of Islamabad. Weed Biology and Management, 6, 89-95.

Shahzadi, F., Malik, M. F., \& Raza, A. (2015). Genetically modified food controversies: A review. International Journal of Scientific \& Engineering Research, 6, 2072-2089.
Shakya, T. (1999). The dragon in the land of snows: A history of modern Tibet since 1947. Columbia University Press.

Sharma, R. (2012). Impacts on human health of climate and land use change in the Hindu Kush-Himalayan region. Mountain Research and Development, 32(4), 480-486.

Sharma, H. R., \& Chauhan, S. K. (2013). Agricultural transformation in trans Himalayan region of Himachal Pradesh: Cropping pattern, technology adoption and emerging challenges. Agricultural Economics Research Review, 26, 173-179.

Sharma, E., Chettri, N., \& Oli, K. P. (2010). Mountain biodiversity conservation and management: A paradigm shift in policies and practices in the Hindu Kush-Himalayas. Ecological Research, 25, 905-923.

Sharma, L. N., Vetaas, O. R., Chaudhary, R. P., \& Maren, I. E. (2014). Ecological consequences of land use change: Forest structure and regeneration across the forest-grassland Ecotone in Mountain Pastures in Nepal. Journal of Mountain Science, 11, 838-849.

Shen, S. C., Xu, G. F., Zhang, F. D., Jin, G. M., Liu, S. F., Liu, M. Y., et al. (2013). Harmful effects and chemical control study of Mikania micrantha H.B.K in Yunnan, Southwest China. African Journal of Agricultural Research, 8, 5554-5561.

Shen, S., Xu, G., Clements, D. R., Jin, G., Liu, S., Zhang, F., et al. (2015). Effects of invasive plant Mikania micrantha on plant community and diversity in farming systems. Asian Journal of Plant Sciences, 14(1), 27-33.

Sheng, J. J., Wang, X. P., Gong, P., Tian, L. D., \& Yao, T. D. (2012). Heavy metals of the Tibetan top soils: Level, source, spatial distribution, temporal variation and risk assessment. Environmental Science and Pollution Research, 19, 3362-3370.

Shrestha, B. (2008). contribution of foreign employment and remittance to Nepalese economy. Nepal Rastra Bank Economic Review, 20, 1 15.

Shrestha, R. M. (2013). Energy use and greenhouse gas emissions in selected Hindu Kush-Himalayan countries. Mountain Research and Development, 33(3), 343-354.

Shrestha, B. B. (2016) Invasive alien plant species in Nepal. In P. K. Jha, M. Siwakoti, \& S. R. Rajbhandary (Eds.), Frontiers of botany (pp. 269-284). Central Department of Botany, Tribhuvan University, Kathmandu.

Shrestha, A. B., \& Aryal, R. (2011). Climate change in Nepal and its impact on Himalayan glaciers. Regional Environmental Change, 11 (1), 65-77.

Shrestha, U. B., \& Bawa, K. S. (2013). Trade, harvest, and conservation of caterpillar fungus (Ophiocordyceps sinensis) in the Himalayas. Biological Conservation, 159, 514-520.

Shrestha, U. B., \& Bawa, K. S. (2015). Harvesters' perceptions of population status and conservation of Chinese caterpillar fungus in the Dolpa region of Nepal. Regional Environmental Change, 15(8), $1731-1741$.

Shrestha, P. M., \& Dhillion, S. S. (2003). Medicinal plant diversity and use in the highlands of Dolakha district, Nepal. Journal of Ethnopharmacology, 86, 81-96.

Shrestha, U. B., Gautam, S., \& Bawa, K. S. (2012). Widespread climate change in the Himalayas and associated changes in local ecosystems. PLoS One, 7(5), e36741.

Shrestha, B. B., Joshi, S., Bisht, N., Yi, S., Kotru, R., Chaudhary, R. P. \& Wu, N. (2018). Inventory and impact assessment of invasive alien plant species in Kailash Sacred Landscape. ICIMOD Working Paper 2018/2. Kathmandu: ICIMOD.

Sidle, R. C., Ghestem, M., \& Stokes, A. (2014). Epic landslide erosion from mountain roads in Yunnan, China - Challenges for sustainable development. Natural Hazards and Earth System Sciences, 14(11), 3093-3104.

Simms, A., Moheb, Z., Ali, S. H., Ali, I., \& Wood, T. (2011). Saving threatened species in Afghanistan: Snow leopards in the Wakhan 
Corridor. International Journal of Environmental Studies, 68, 299 312.

Singh, S. P., Bassignana-Khadka, I., Karky, B. S., \& Sharma, E. (2011). Climate change in the Hindu Kush-Himalayas: The state of current knowledge. Kathmandu: ICIMOD.

Singh, R., Rishi, M. S., \& Sidhu, N. (2016). An overview of environmental impacts of riverbed mining in Himalayan terrain of Himachal Pradesh. Journal of Applied Geochemistry, 18(4), 473479.

Song, X., Yang, G., Yan, C., Duan, H., Liu, G., \& Zhu, Y. (2009). Driving forces behind land use and cover change in the Qinghai-Tibetan Plateau: A case study of the source region of the Yellow River, Qinghai Province, China. Environmental Earth Sciences, 59, 793-801.

Sood, A., Singh, K. D., Pandey, P., \& Sharma, S. (2008). Assessment of bacterial indicators and physicochemical parameters to investigate pollution status of Gangetic river system of Uttarakhand (India). Ecological Indicators, 8, 709-717.

Starkey, P. (2001). Animal power: Appropriate transport in mountain areas. In T. Kohler, et al. (Eds.), Mountains of the world: Mountains, energy, and transport. Bern, Switzerland: Mountain Agenda.

Starr, S. F. (2006). Conflict and peace in mountain societies. In M. Price, L. Jansky, \& A. A. Iatsenia (Eds.), Key issues for mountain areas (pp. 169-180). Tokyo: United Nations University Press.

Storper, M. (1995). The resurgence of regional economies, ten years later: The Region as a Nexus of untraded Interdependencies. European Urban and Regional Studies, 2(3), 191-221. http:// journals.sagepub.com/doi/abs/.

Su, B., Xiao, C., Deka, R., Seielstad, M. T., Kangwanpong, D., Xiao, J., et al. (2000). Y chromosome haplotypes reveal prehistorical migrations to the Himalayas. Human Genetics, 107(6), 582-590.

Sujoy, Y. H., Sattagi, H. N., \& Patil, R. K. (2010). Invasive alien insects and their impact on agroecosystem. Karnataka Journal of Agricultural Sciences, 23, 26-34.

Takeuchi, N., et al. (2009). A shallow ice core re-drilled on the dunde ice cap, Western China: Recent changes in the Asian high mountains. Environmental Research Letters, 4(4), 1-6.

Tang, R. G., Luo, J., She, J., Chen, Y. C., Yang, D. D., \& Zhou, J. (2015). The cadmium and lead of soil in timberline coniferous forests, Eastern Tibetan Plateau. Environmental Earth Sciences, 73, 303-310.

Taylor, L. H., Latham, S. M., \& Woolhouse, M. E. (2001). Risk factors for human disease emergence. Philosophical Transactions of the Royal Society B Biological Sciences, 356(1411), 983-989.

Thapa, D., \& Sein, M. K. (2010). ICT, Social capital and development: the case of a mountain region in Nepal. In Proceedings of Third Annual SIG GlobDev Workshop, Saint Louis, USA, December 12, 2010.

Tibet travel arrivals exceed 20 million in 2015 (translated from Chinese). (2016). http://www.tibetcn.com/news/xzly/ 201601283081.html. Accessed 11 Sept. 2016.

Tilman, D., Polasky, S., \& Lehman, C. (2005). Diversity, productivity and temporal stability in the economies of humans and nature. Journal of Environmental Economics and Management, 49(3), 405426. http://linkinghub.elsevier.com/retrieve/pii/S0095069604001160. Accessed 21 July 2014.

Tiwari, A. K. (2000a). Infrastructure and economic development in Himachal Pradesh. New Delhi: Indus Publishing.

Tiwari, P. C. (2000b). Land-use changes in Himalaya and their impact on the plains ecosystem: Need for sustainable land use. Land Use Policy, 17(2), 101-111.

Tiwari, P. C., \& Joshi, B. (2015). Climate change and rural out-migration in Himalaya. Change and Adaptation in Socio-Ecological Systems, 2, 8-25.
Tiwari, P. C., \& Joshi, B. (2016). Rapid urban growth in mountainous regions: The case of Nainital, India. Urbanization and Global Environmental Change Project (UGEC). UGEC Viewpoints. https:// ugecviewpoints.wordpress.com/2016/03/29/rapid-urban-growth-inmountainous-regions-the-case-of-nainital-india/. Accessed 4 Sept. 2016.

Tiwari, S., Adhikari, B., Siwakoti, M., \& Subedi, K. (2005). An inventory and assessment of invasive alien plant species of Nepal. Nepal: IUCN-The World Conservation Union.

Toffin, G., \& Pfaff-Czarnecka, J. (Eds.). (2014). Facing globalization in the Himalayas: Belonging and the politics of the self (Vol. 5). SAGE Publications India.

Tong, Y. D., Chen, L., Chi, J., Zhen, G. C., Zhang, Q. Q., Wang, R. N., et al. (2016). Riverine nitrogen loss in the Tibetan Plateau and potential impacts of climate change. Science of the Total Environment, 553, 276-284.

Tourism Council of Bhutan. (2015). Bhutan Tourism Monitor 2015. http://tcb.cms.ebizity.net/attachments/tcb_081415_btm-2015booklet-(web).pdf. Accessed 11 Sept. 2016.

Tse-ring, K., Sharma, E., Chettri, N., \& Shrestha, A. (Eds.). (2010). Climate change vulnerability of mountain ecosystems in the Eastern Himalayas; Climate change impact a vulnerability in the Eastern Himalayas-Synthesis report. Kathmandu: ICIMOD.

Tsing, A. (2005). Friction: Ethnography of global encounters (pp. 120). New Jersey: Princeton University Press.

Tulachan, P. M. (2001). Mountain agriculture in the Hindu Kush-Himalaya: A regional comparative analysis. Mountain Research and Development, 21(3), 260-267.

Uddin, K., Murthy, M. S. R., Wahid, S. M., \& Matin, M. A. (2016). Estimation of soil erosion dynamics in the Koshi basin using GIS and remote sensing to assess priority areas for conservation. PLoS One, 11(3), 1-19.

Ueda, A., \& Samdup, T. (2010). Chili transactions in Bhutan: An Economic, social and cultural perspective. Bulletin of Tibetology, (Special Issue) 45(2), 46(1).

UNCTAD World Investment Report. (2009). Transnational corporations, agricultural production and development. Geneva.

Underdal, A. (2010). Complexity and challenges of long term environmental governance. Global Environmental Change, 20(3), 386-393. https://doi.org/10.1016/j.gloenvcha.2010.02.005.

UNEP. (2002). Civil society statement on international environmental governance. In Seventh special session of the UNEP Governing Council/GMEF, Cartagena, Colombia, February 2002.

UNEP. (2008). International environmental governance and the reform of the United Nations. In XVI Meeting of the Forum of Environment Ministers of Latin America and the Caribbean.

UNFPA (United Nations Population Fund). (2007). State of world population 2007: Unleashing the potential of urban growth. New York: United Nations Population Fund.

UNHCR. (2015). Global trends forced displacement in 2015. The UN Refugee Agency.

United Nations. (2003). Fertility, contraception and population polices. Department of Economic and Social Affairs, Population Division. New York, United Nations. ESA/A/WP.182.

United Nations. (2012). Changing levels and trends in mortality: The role of patterns of death by cause. United Nations Publication.

United Nations. (2014). World urbanization prospects: The 2014 Revision, Highlights. Department of Economic and Social Affairs, Population Division (ST/ESA/SER.A/352).

United Nations. (2015a). World population prospects: The 2015 Revision, custom data acquired via website. http://esa.un.org/ unpd/wpp/DataQuery/.

United Nations. (2015b). World population prospects: The 2015 revision, key findings and advance table. 
UN-HABITAT (United Nations Human Settlements Programme). (2010). The state of Asian cities 2010/11. Regional Office for Asia and the Pacific. Fukuoka. http://unhabitat.org/books/the-state-ofasian-cities-201011/. Accessed 4 Sept. 2016.

Uniyal, S. K., Awasthi, A., \& Rawat, G. S. (2002). Current status and distribution of commercially exploited medicinal and aromatic plants in upper Gori valley, Kumaon Himalaya, Uttaranchal. Current Science, 82, 1246-1252.

Upreti, B. R., Subedi, B., KC, S., Ghale, Y., \& Shivakoti, S. (2016). Understanding dynamics of rural agriculture and employment in Nepal: Evidences from Ilam district of Eastern Nepal. Nepalese Journal of Agricultural Sciences 1(4), 132-141. http://www.hicast. edu.np/uploads/colleges/16/582eab6d9e293.pdf. Accessed 12 Dec. 2017.

Uprety, Y., Boon, E. K., Poudel, R. C., Shrestha, K. K., Rajbhandary, S., Ahenkan, A., et al. (2010). Non-timber forest products in Bardiya district of Nepal: Indigenous use, trade and conservation. Journal of Human Ecology, 30(3), 143-158.

Uprety, Y., Poudel, R. C., Gurung, J., Chettri, N., \& Chaudhary, R. P. (2016). Traditional use and management of NTFPs in Kangchenjunga Landscape: implications for conservation and livelihoods. Journal of Ethnobiology and Ethnomedicine, 3, 19. https://doi.org/ 10.1186/s13002-016-0089-8.

Vaidya, R. (2012). Water and hydropower in the green economy and sustainable development of the Hindu Kush-Himalayan Region. Hydro Nepal: Journal of Water, Energy and Environment, 10, $11-19$.

Valério, E., Gadanho, M., \& Sampaio, J. P. (2008). Reappraisal of the Sporobolomyces Roseus species complex and description of sporidiobolus metaroseus $\mathrm{Sp}$. Nov. International Journal of Systematic \& Evolutionary Microbiology, 58(3), 736-741.

Wan, F.-H., \& Yang, N.-W. (2016). Invasion and management of agricultural alien insects in China. Annual Review of Entomology, 61, 77-98.

Wang, F., et al. (2015). China, the millennium development goals, and the post-2015 development agenda. Beijing.

Wang, H., Zhou, X., Wan, C., Fu, H., Zhang, F., \& Ren, J. (2008). Eco-environmental degradation in the northeastern margin of the Qinghai-Tibetan Plateau and comprehensive ecological protection planning. Environmental Geology, 55(5), 1135-1147.

Wang, H., Wang, Q., Bowler, P. A., \& Xiong, W. (2016). Invasive aquatic plants in China. Aquatic Invasions, 11, 1-9.

Watanabe, T., Lamsal, D., \& Ives, J. D. (2009). Evaluating the growth characteristics of a glacial lake and its degree of danger of outburst flooding: Imja Glacier, Khumbu Himal, Nepal. Norsk Geografisk Tidsskrift, 63, 255-267.

Webb, N. P., \& Stokes, C. J. (2012). Climate change scenarios to facilitate stakeholder engagement in agricultural adaptation. Mitigation and Adaptation Strategies for Global Change, 17(8), 957-973.

Weber, E., Sun, S. G., \& Li, B. (2008). Invasive alien plants in China: Diversity and ecological insights. Biological Invasions, 10, 1411-1429.

Wen, L., Dong, S., Li, Y., Li, X., Shi, J., Wang, Y., et al. (2013). Effect of degradation intensity on grassland ecosystem services in the alpine region of Qinghai-Tibetan Plateau, China. PLoS One, 8(3), e58432.

Winkler, D. (2009). Caterpillar fungus (Ophiocordyceps sinensis) production and sustainability on the Tibetan Plateau and in the Himalayas. Asian Medicine, 5(2), 291-316.

World Bank. (1994). World development report (1994). Infrastructure for development. Oxford and New York: Oxford University Press for the World Bank.

World Bank. (2014). Nepal road sector assessment study.
World Bank. (2015). Population data in the world. http://data. worldbank.org/indicator/SP.POP.TOTL.

World Bank. (2016). World bank data. http://data.worldbank.org/ indicator/. Accessed 10 Sept. 2016.

World Health Organization. (2009). Global health risks: mortality and burden of disease attributable to selected major risks. World Health Organization.

World Water Assessment Programme. (2009). Water in a changing world. The United Nations World Water Development Report 3. UNESCO.

Wu, Q., Zhang, T. (2008). Recent permafrost warming on the Qinghai-Tibetan Plateau. Journal of Geophysical Research, 113 (D13), D13108. http://doi.wiley.com/10.1029/2007JD009539.

Wu, Q., Zhang, T., \& Liu, Y. (2010). Permafrost temperatures and thickness on the Qinghai-Tibet Plateau. Global and Planetary Change, 72(1-2), 32-38.

Wu, N., Rawat, G. S., Joshi, S., Ismail, M., \& Sharma, E. (2013). High-altitude rangelands and their interfaces in the Hindu-Kush Himalayas (pp. 1-189). Kathmandu: ICIMOD.

Wu, N., Ismail, M., Joshi, S., Qamar, F. M., Phuntsho, K., Weikang, Y., et al. (2014a). Understanding the transboundary Karakoram-Pamir landscape. Feasibility and baseline studies \#1. Kathmandu: ICIMOD.

Wu, N., Ismail, M., Joshi, S., Yi, S., Shrestha, R. M., \& Jasra, A. W. (2014b). Livelihood diversification as an adaptation approach to change in the pastoral Hindu-Kush Himalayan region. Journal of Mountain Science, 11, 1342-1355.

Wu, J., Duan, D. P., Lu, J., Luo, Y. M., Wen, X. H., Guo, X. Y., et al. (2016a). Inorganic pollution around the Qinghai-Tibet Plateau: An overview of the current observations. Science of the Total Environment, 550, 628-636.

Wu, N., Yi, S. L., Joshi, S., \& Bisht, N. (Eds.). (2016b). Yak on the move-Transboundary challenges and opportunities for yak raising in a changing Hindu Kush Himalayan Region. Kathmandu, Nepal: International Centre for Integrated Mountain Development.

Xinhua. (2015). Tibet sees record high tourist arrivals in 2014. English news, 2015-01-11. www.xinhuanet.com.

Xu, J., \& Grumbine, R. E. (2014). Building ecosystem resilience for climate change adaptation in the Asian Highlands. Climate Change, 5, 709-718.

Xu, H., Ding, H., Li, M., Qiang, S., Guo, J., Han, Z., et al. (2006). The distribution and economic losses of alien species invasion to China. Biological Invasions, 8, 1495-1500.

Xu, J. C., Sharma, R., Fang, J., \& Xu, Y. F. (2008a). Critical linkages between land use transition and human health in the Himalayan region. Environment International, 34(2), 239-247.

Xu, J. C., Yang, Y., Li, Z. Q., Tashi, N., Sharma, R., \& Fang, J. (2008b). Understanding land use, livelihood and health transition of Tibetan nomads: A case from Gangga Township, Dingri County, TAR of China. EcoHealth, 5(2), 104-114.

Xu, J., Sharma, R., Fang, J., \& Xu, Y. (2008c). Critical linkages between land-use transition and human health in the Himalayan Region. Environment International, 34(2), 239-247.

Xu, J. C., Yang, Y., Li, Z., Tashi, N., Sharma, R., \& Fang, J. (2008d). Understanding land use, livelihoods, and health transitions among Tibetan Nomads: A case from Gongga Township, Dingri County. Tibetan Autonomous Region of China. EcoHealth, 5(2), 104-114.

Xu, J., Grumbine, R. E., Shrestha, A., Eriksson, M., Yang, X., Wang, Y. U. N., et al. (2009). The melting Himalayas: cascading effects of climate change on water, biodiversity, and livelihoods. Conservation Biology, 23(3), 520-530.

Xu, H., Qiang, S., Genovesi, P., Ding, H., Wu, J., Meng, L., et al. (2012). An inventory of invasive alien species in China. NeoBiota, $15,1-26$. 
Xue, X., Guo, J., Han, B. S., Sun, Q. W., \& Liu, L. C. (2009). The effect of climate warming and permafrost thaw on desertification in the Qinghai-Tibetan Plateau. Geomorphology, 108, 182-190.

Yadav, M., \& Dugaya, D. (2013). Non-timber forest products certification in India: Opportunities and challenges. Environment, Development and Sustainability, 15, 567-586.

Yadav, I. C., Devi, N. L., Li, J., Zhang, G., \& Shakya, P. R. (2016). Occurrence, profile and spatial distribution of organochlorines pesticides in soil of Nepal: Implication for source apportionment and health risk assessment. Science of the Total Environment, 573, 1598-1606.

Yan, Z., \& Wu, N. (2005). Rangeland privatization and its impacts on the Zoige wetlands on the Eastern Tibetan Plateau. Journal of Mountain Science, 2, 105-115.

Yang, M., Wang, S., Yao, T., Gou, X., Lu, A., \& Guo, X. (2004). Desertification and its relationship with permafrost degradation in Qinghai-Xizang (Tibet) plateau. Cold Regions Science and Technology, 39, 47-53.

Yang, M., et al. (2010a). Permafrost degradation and its environmental effects on the Tibetan Plateau: A review of recent research. Earth-Science Reviews, 103(1-2), 31-44.

Yang, M. X., Nelson, F. E., Shiklomanov, N. I., Guo, D. L., \& Wan, G. N. (2010b). Permafrost degradation and its environmental effects on the Tibetan Plateau: A review of recent research. Earth-Science Reviews, 103, 31-44.

Yao, T., et al. (2007). Recent glacial retreat and its impact on hydrological processes on the Tibetan Plateau, China, and surrounding regions. Arctic, Antarctic, and Alpine Research, 39(4), $642-650$

Yasuoka, J., \& Levins, R. (2007). Impact of deforestation and agricultural development on anopheline ecology and malaria epidemiology. American Journal of Tropical Medicine and Hygeine, 76(3), 450-460.

Yuan, G. L., Wu, M. Z., Sun, Y., Li, J., Li, J. C., \& Wang, G. H. (2016). One century of air deposition of hydrocarbons recorded in travertine in North Tibetan Plateau, China: Sources and evolution. Science of the Total Environment, 560, 212-217.

Zhang, G., et al. (2011). Monitoring lake level changes on the Tibetan Plateau using ICESat altimetry data (2003-2009). Remote Sensing of Environment, 115(7), 1733-1742.

Zhang, F., Yan, X. D., Zeng, C., Zhang, M., Shrestha, S., Devkota, L. P., et al. (2012a). Influence of traffic activity on heavy metal concentrations of roadside farmland soil in mountainous areas. International Journal of Environmental Research, 9, 1715-1731.

Zhang, H., Wang, Z. F., Zhang, Y. L., \& Hu, Z. J. (2012b). The effects of the Qinghai-Tibet railway on heavy metals enrichment in soils. Science of the Total Environment, 439, 240-248.
Zhang, Y. L., Kang, S. C., Li, C. L., Cong, Z. Y., \& Zhang, Q. G. (2012c). Wet deposition of precipitation chemistry during 20052009 at a remote site (Nam Co Station) in central Tibetan Plateau. Journal of Atmospheric Chemistry, 69, 187-200.

Zhang, H., Zhang, Y. L., Wang, Z. F., \& Ding, M. J. (2013). Heavy metal enrichment in the soil along the Delhi-Ulan section of the Qinghai-Tibet railway in China. Environmental Monitoring and Assessment, 185, 5435-5447.

Zhang, S. P., Hou, L. N., Wei, C. J., Zhou, X. N., \& Wei, N. (2015a). Study on water quantity and quality-integrated evaluation based on the natural-social dualistic water cycle. Polish Journal of Environmental Studies, 24, 829-840.

Zhang, Y., Wang, L., Hu, Y., Xi, X. F., Tang, Y. S., Chen, J. H., et al. (2015b). Water organic pollution and eutrophication influence soil microbial processes, increasing soil respiration of estuarine wetlands: Site study in Jiuduansha Wetland. PLoS One, 10, e0126951.

Zhang, J., Liu, R., Deng, W., et al. (2016). Characteristics of landslide in Koshi River Basin, Central Himalaya. Journal of Mountain Science, 13, 1711-1722. https://doi.org/10.1007/s11629-016-4017-0.

Zhang, J., Regmi, A. D., Liu, R., et al. (2017). Landslides inventory and trans-boundary risk management in Koshi river basin, Himalaya. In A. Li, W. Deng, W. Zhao (Eds.), Land cover change and its eco-environmental responses in Nepal. Singapore: Springer.

Zhao, W. Y., Li, J. L., \& Qi, J. G. (2007). Changes in vegetation diversity and structure in response to heavy grazing pressure in the northern Tianshan Mountains, China. Journal of Arid Environments, 68(3), 465-479.

Zhao, N., Lu, X. W., \& Chao, S. G. (2014). Level and contamination assessment of environmentally sensitive elements in smaller than $100 \mathrm{mu} \mathrm{m}$ street dust particles from Xining, China. International Journal of Environmental Research and Public Health, 11, 25362549.

Zhao, N., Lu, X. W., Chao, S. G., \& Xu, X. (2015). Multivariate statistical analysis of heavy metals in less than $100 \mu \mathrm{m}$ particles of street dust from Xining,China. Environmental Earth Sciences, 73, 2319-2327.

Zhou, H. K., Zhao, X. Q., Zhao, L., Li, Y. N., Wang, S. P., Xu, S. X., et al. (2008). Restoration capability of alpine meadow ecosystem on Qinghai-Tibetan Plateau. Chinese Journal of Ecology, 27, 697-704.

Zhou, D. N., Zhang, F. P., Duan, Z. Y., Liu, Z. W., Yang, K. L., Guo, R., et al. (2013). Effects of heavy metal pollution on microbial communities and activities of mining soils in Central Tibet, China. Journal of Food Agriculture and Environment, 11, 676-681.

Zomer, R., \& Oli, K. P. (Eds.). (2011). Kailash sacred landscape conservation initiative - Feasibility assessment report. Kathmandu: ICIMOD.

\footnotetext{
Open Access This chapter is licensed under the terms of the Creative Commons Attribution 4.0 International License (http:// creativecommons.org/licenses/by/4.0/), which permits use, sharing, adaptation, distribution and reproduction in any medium or format, as long as you give appropriate credit to the original author(s) and the source, provide a link to the Creative Commons license and indicate if changes were made.
}

The images or other third party material in this chapter are included in the chapter's Creative Commons license, unless indicated otherwise in a credit line to the material. If material is not included in the chapter's Creative Commons license and your intended use is not permitted by statutory regulation or exceeds the permitted use, you will need to obtain permission directly from the copyright holder. 